\title{
The Jurassic-Cretaceous depositional and tectonic evolution of the southernwestern margin of the Neotethys ocean, northern Oman and United Arab Emirates
}

\author{
Emrys R. Phillips ${ }^{1 *}$, Colin N. Waters ${ }^{2}$ \& Richard A. Ellison ${ }^{2}$ \\ 1 British Geological Survey, Murchison House, West Mains Road, Edinburgh EH9 3LA \\ *e-mail address of corresponding author: erp@bgs.ac.uk \\ 2 British Geological Survey, Kingsley Dunham Centre, Keyworth, Nottingham NG12 5GG
}

Keywords: Neotethys; basin evolution; Jurassic; Cretaceous, UAE; Oman

\begin{abstract}
The concept that the autochthonous, parautochthonous and allochthonous Permian-Cretaceous sequences in the United Arab Emirates (UAE) and Oman record the transition from platform, slope to basin sedimentation within the southern part of Neotethys has been fundamental to the interpretation of the geological history of the region. The results of a major geological mapping programme of the UAE, carried out by the British Geological Survey for the Federal Government of the UAE, coupled with the detailed examination of key sections within northern Oman has led to a re-evaluation of the geological evolution of this region. This detailed study has led to a greater appreciation of the sedimentology and depositional setting of the sediments laid down along the northeastern Arabian continental margin during the Jurassic to Cretaceous, allowing a more refined model of Neotethys Ocean basin evolution to be established. The model charts the progressive breakup of the Arabian continental margin and closure of Neotethys during the mid to late Cretaceous and is divided into three main stages: Stage 1 - Initial rifting and formation of the Neotethys Ocean, followed by a prolonged period of stable, passive margin sedimentation which extended from the Permian to Late Jurassic times; Stage 2 - Uplift and erosion of the shelf margin during the Late Jurassic to Early Cretaceous, coincident with increased carbonate-clastic sedimentation in the outer ramp, distal slope and basinal areas; Stage 3 - Increased instability during the Late Cretaceous leading to the breakup of the platform margin and foreland basin sedimentation accompanying the obduction of the Oman-UAE ophiolite. Data obtained for the upper part of the platform and platform margin to slope successions has revealed that the topography of the "shelf"-slope-basinal margin was more subdued than previously thought, with this more gentle ramp margin morphology persisting until early to midCretaceous times when the platform margin started to become unstable during ophiolite obduction. The thrust-repeated allochthonous sedimentary rocks of the Hamrat Duru Group were deposited on the outer platform margin/lower slope rise to basinal plain of this basin margin and includes the dismembered remains of two turbidite fan systems which fed carbonate-rich detritus into deeper parts of the ocean. A re-evaluation of the chert-rich sequences, previously equated with deposition on the abyssal plain of Neotethys, has led to the conclusion that they may record sedimentation at a much shallower level within a starved ocean basin, possibly in a mid-ramp (above storm wave base) to outer ramp setting. A marked change in basin dynamics occurred during the mid-Cretaceous leading to the development of a shallow ramp basin margin in Oman with terrestrial to shallow marine sedimentary rocks interdigitating with red siliceous mudstones. By contrast, the contemporaneous succession in the Dibba Zone of the UAE indicates considerable instability on a steep shelf break. This instability is recorded by the presence of several major olistostrome deposits within the Aruma Group of the UAE which are thought to have been generated in advance of the rapidly obducting Oman-UAE ophiolite.
\end{abstract}




\section{INTRODUCTION}

The primary objective of this paper is to re-assess the Jurassic-Cretaceous depositional and tectonic evolution of the southern margin of Neotethys. This re-evaluation is largely based on mapping at the 1:25,000 and 1:50,000 scales of the UAE undertaken by the British Geological Survey between 2002 and 2006 (Styles et al. 2006). During the course of this work the definitions of the main stratigraphical units and tectonic evolutionary history established by Glennie et al. (1974) and followed by Searle et al. (1983), Robertson et al. (1987), and Robertson and Searle (1990) were evaluated. The principle concept that the autochthonous, parautochthonous and allochthonous sequences in the UAE record the transition from platform, slope to basin sedimentation has been fundamental to the interpretation of the geological history of the region. However, the results of the regional mapping programme suggested that refinement of this model was appropriate and in order to obtain further evidence, field work was undertaken in northern Oman where visits to the type sections of sediments coeval to those in the UAE were examined. This enabled a better regional appreciation of the sedimentology and depositional setting of the sediments laid down along the northeastern Arabian continental margin during the Jurassic to Cretaceous, allowing a more refined model of Neotethys Ocean basin evolution to be established. For a more detailed account of the results, including sedimentological and structural data, of the regional mapping of the UAE and the comparative study undertaken in northern Oman can be found in Ellison et al. (2006a, b, c), Farrant et al. (2006), Phillips et al. (2006a, b, c) and Styles et al. (2006).

A considerable volume of work relating to the Jurassic and Cretaceous sequences in Arabia as a whole has accumulated in the past 15 years or so, largely concerned with detailed sequence stratigraphical interpretation of the reservoir and related sequences in the platform successions. Major compilations of numerous papers include Forbes et al. (2010), Sharland et al. (2001) and van Buchem et al. (2009), and papers in van Buchem et al. (2010) and Leturmy and Robin (2010). Whereas many of the contributions to these volumes focus on relatively aspects of the stratigraphy and structure, the present paper provides a regional stratigraphical framework and palaeogeographical reconstruction of this important period in the evolution of the Arabian continental margin.

\section{GEOLOGICAL SETTING}

The geological evolution of the United Arab Emirates (UAE) and northern Oman during the Mesozoic can be directly related to the opening of the southern Neotethys Ocean during the Triassic and its eventual closure in Late Cretaceous to Palaeogene times. The majority of the rock units in this area were formed within Neotethys, but their present-day distribution is largely the result of processes associated with closure of this ocean. The geology of the Musandam Peninsula, the northern tip of the UAE and Oman, is dominated by the carbonate platform succession of the Hajar Supergroup (Fig. 1) (Hudson et al. 1954a, b; Glennie et al. 1974; Biehler et al. 1975; Ricateau and Riché 1980; Robertson and Searle 1990; Robertson et al. 1990a, b; Béchennec et al. 1993; Le Métour et al. 1993; Styles et al. 2006). This thick (c. $3800 \mathrm{~m}$ ), relatively continuous limestone succession was deposited on the Arabian continental passive margin of Neotethys between Permian and Early Cretaceous times. The supergroup is also extensively exposed within the Hajar (Oman) Mountains to the south, in particular in the Jebal Akhdar and Al Hajar Ash Sharqi mountain ranges. The passive margin succession is succeeded by the Late Cretaceous Aruma Group, comprising: a lower part deposited following uplift 
and erosion of the carbonate platform, together with platform-edge debris flow conglomerates generated during the break up of this margin; and an upper part, representing the initiation of the foreland basin. The deeper water equivalents of the Aruma Group carbonate platform succession, which include carbonate turbidites, pelagic lime-mudstones, siliceous mudstones and cherts, occur within the Dibba Zone of the UAE, and Qumayrah and Jebel Akhdar areas of Oman (Fig. 1). In the Dibba Zone, these deepwater sedimentary rocks also include a number of regional-scale olistostromes, which were generated in response to active faulting during the breakup of the platform margin and obduction of the Oman-UAE (Semail) ophiolite during Late Cretaceous times (Styles et al. 2006).

Sedimentary rocks laid down within deeper parts of Neotethys are variably exposed in a 10 to $50 \mathrm{~km}$ wide, structurally complex zone which extends from the northeastern UAE (Dibba Zone), along the western side of the Hajar Mountains into northern Oman (e.g. Hamrat Duru Mountains) (Glennie et al. 1974; Lippard et al. 1982; Searle et al. 1983; Robertson et al. 1990a, b; Wilson 2000). The Lower Jurassic to Upper Cretaceous Hamrat Duru Group, deposited on the slope of the ocean basin, comprises a sequence of turbiditic clastic limestones and conglomerates that interdigitate with deepwater, basinal facies rocks. The radiolarian cherts and siliceous mudstones have previously been interpreted as recording deposition on the abyssal plain of the ocean. These basinal sequences include the Triassic to Lower Cretaceous Shamal Chert Formation and the Upper Jurassic to Lower Cretaceous Sid'r Chert Formation. Deposition within Neotethys was punctuated by localised alkaline and tholeiitic within-plate volcanism leading to the eruption of, for example, the Cretaceous Dibba and Hatta volcanic formations.

The geology of the remainder of the Hajar Mountains, in both the UAE and Oman, is dominated by the Oman-UAE ophiolite (see Fig. 1). This ophiolite represents a slab of oceanic crust and mantle obducted onto the eastern continental margin of the Arabian platform during the late Cretaceous (Lippard et al. 1986; Styles et al. 2006). During obduction the slope and basinal successions within Neotethys were thrust over the autochthonous or parautochthonous (probably having been displaced a relatively small distance) carbonate platform succession, to form an allochthonous imbricate thrust stack several kilometres thick. Obduction also resulted in the loading of the Arabian platform and the development of a foreland basin between the ophiolite and an emergent peripheral swell. This basin was filled by an Upper Cretaceous to Palaeogene cover sequence exposed along the western edge of the Hajar Mountains. Both the Mesozoic and Palaeogene sedimentary sequences were affected by later (post-obduction) thrusting and folding associated with the development of the Zagros Mountains.

Specific sections examined for the work presented in this paper included the well known Wadi Mi'aidin platform succession at Jebal Akdhar, Oman (Fig. 1). Observations in the lower part of the Aruma Group revealed new information on the form of the basin margin at this important time in the evolution of Neotethys. The transition from platform margin to slope sedimentation, typically equated with the Jurassic to mid Cretaceous Mayhah Formation (Sumeini Group, Glennie et al. 1974), were examined in the Jebal Sumeini and Qumayrah areas of Oman, and in the Dibba Zone in the UAE (Fig. 1). In addition, a comparison was made between the thrust-repeated allochthonous sedimentary rocks deposited on the outer platform margin/lower slope rise to basinal plain, represented by the Hamrat Duru Group, in the type areas of the Sid'r Chert, Dhera Limestone, Nayid and Wahrah formations in northern Oman, with similar successions in the Dibba and Hatta zones of the UAE (Fig. 1). This has led to the development of a new model for the progressive breakup of the Arabian continental margin and closure of Neotethys during the mid to late Cretaceous. 


\section{REGIONAL STRATIGRAPHY AND DEPOSITIONAL SETTING}

The Jurassic to Cretaceous sedimentary succession within the UAE and northern Oman (Fig. 2), deposited along the southern margin of Neotethys, can be assigned to five main palaeogeographical settings, namely: (i) platform; (ii) platform margin; (iii) outer platform margin to basin; (iv) basinal sedimentary and volcanic rocks; and (v) syn- and post-obduction foreland basin. The lithological characteristics, thickness, depositional setting and age range of the key lithostratigraphical units are summarised in Tables 1-5. For a more detailed description of the lithostratigraphy of the autochthonous, parautochthonous and allochthonous sequences in the UAE and Oman the reader is referred to Styles et al. (2006) and Glennie et al. (1974), and references therein.

\section{Carbonate platform succession of the Hajar Supergroup}

The shallow marine to intertidal carbonate platform succession developed on the Arabian continental passive margin in the UAE and Oman are represented by the Permian to Lower Cretaceous Hajar Supergroup (Allemann and Peters 1972; Glennie et al. 1974; Biehler et al. 1975; Ricateau and Riché 1980; Searle et al. 1983; Robertson et al. 1990a, b; Robertson and Searle 1990; Styles et al. 2006). The Jurassic to mid Cretaceous part of this supergroup, which forms the focus of this present study, comprises the Musandam, Thamama and Wasia groups (Fig. 2). The Musandam Group (oldest) crops out entirely within the Musandam Peninsula (see Fig. 1) and key sections have been described in detail by Alsharhan and Nairn (1997) and Styles et al. (2006). Correlatives of the Musandam Group include the Sahtan Group of Jebal Akhdar (Figs. 1 and 2), and the Hamlah, Izhara, Araej, Diyab and Hith formations in the subsurface of the UAE. The Thamama Group in the UAE has previously been described by Toland et al. (1993), van Buchem et al. (2002a) and Styles et al. (2006), and from the Jebal Akhdar area by van Buchem et al. (2002a, b) and Borgomano et al. (2002). The interpretation of the depositional environments of these groups (see Table 1) is derived from these publications.

\section{Musandam Group}

The rather monotonous succession of variably dolomitised wackestones and packstones of the Musandam Group (Table 1) was deposited on a shallow water carbonate ramp. The lower part of the group (Musandam 1 Formation; Table 1) was deposited in a low energy, near-shore environment, including tidal mud flats and sabkhas. Bioclastic and peloidal limestones within the sequence are interpreted as recording the periodic development of slightly deeper water, moderate- to high-energy environments, with interbedded thick units of oncoidal limestone probably formed in restricted, shallow marine conditions. The overlying rhythmically bedded sequence (Musandam 2 Formation; Table 1) charts a regular fluctuation of depositional environments, from protected lagoons (oncoidbearing limestones) to high-energy shoals (cross-bedded grainstones), through to a more open-marine shelf (bioclastic lime-packstones and bioclastic lime-wackestones). The increase in grainstones (some containing coral debris) and minor intraformational limestone conglomerates towards the top of the group (Musandam 3 Formation; Table 1) records an overall increase in the energy of the environment, with deposition occurring at, or close to, the ramp margin.

\section{Thamama Group}

In the UAE, the Lower Cretaceous Thamama Group (Table 1), which unconformably overlies the Musandam Group, comprises calcirudites at its base, overlain by a coarsening and thickening upwards, locally channelised sequence of limestones deposited in a lower slope environment. Large 
blocks of coral-bearing grainstone, derived from the underlying Musandam Group, as well as Thamama Group lime-mudstones within the basal conglomerates provide clear evidence of significant (penecontemporaneous) erosion of the platform during their deposition.

In contrast to the UAE, in the Jebal Akhdar area of Oman (see Fig. 1) the Thamama Group records the progradation of an evolving ramp (Kharaib Formation) to shelf (Shuaiba Formation) carbonate system into Neotethys. The well-bedded, bioturbated and bivalve-rich wackestones/packstones, which form lower part of the Kharaib Formation (Unit A) (Figs. 3 and 4a), are interpreted as a high-energy shallow water succession, deposited in a system of bars and intervening channels. This is overlain by orbitolinid packstones laid down in a protected argillaceous lagoon (van Buchem et al. 2002a). The subsequent upward-thickening, weakly bedded sequence of micrites and wackestone/orbitolinid packstone interbeds (Unit B) (Table 1; Figs. 3 and 4a) record deposition in more open-marine, subtidal (above storm wave base) environment (van Buchem et al. 2002a), with the presence of stylolites associated with burrowed hardgrounds near the base of Unit B indicative of periodic (ephemeral) exposure. An Ostrea Bed, at the top of this open-marine succession, was deposited by a succession of high-energy, shallow water bars and channels with debris sourced from associated rudist bioherms (van Buchem et al. 2002a). Thinly bedded limestones in the upper part of the Kharaib Formation (Unit C; Table 1) contain common orbitolinids and Thalassinoides burrows, and are interpreted as a protected argillaceous lagoon sequence (van Buchem et al. 2002a) with packstone interbeds recording occasional storm reworking.

The microbial boundstones (Bacinella-Lithocodium association) which form the lower part of the Shuaiba Formation have previously been interpreted as a low biodiversity (miliolid foraminifera) sequence deposited in a restricted inner shelf setting (Borgomano et al. 2002). The rudist facies, including caprotinid, monopleurid and requienid wackestones, present within the upper part of this formation, corresponds to more open environments within the inner shelf zone (Borgomano et al. 2002). The Caprinid rudist facies, which is restricted to the Nakhl area of northeastern Jebal Akhdar, is interpreted by Borgomano et al. (2002) as having accumulated in an open-marine high energy outer shelf. Masse et al. $(1997,1998)$ have reinterpreted this mainly Albian carbonate succession, which they refer to as the Al Hassanat Formation, as deposits within a narrow fault-bounded platform located between the main platform and the basin. These marginal platform carbonates are time equivalent with the Nahr Umr Formation deposited in the intra-shelf Bab Basin. A steep shelf slope, possibly fault-controlled, marks the rapid transition to deeper water grainstone lobes, debris flows, rock-fall deposits and neptunian dykes located to the north-east of the Jebal Akhdar massif (Borgomano et al. 2002; Masse et al. 1998).

\section{Wasia Group}

In the UAE the Wasia Group was laid down in a shallow water, possibly restricted or lagoonal, shelf setting (Styles et al. 2006). The increasing number of hardgrounds towards the top of the group records an overall shallowing upwards. In Wadi Mi'aidin (see Fig. 3), the interbedded peloidal Orbitolina packstones, wackestones and mudstones of the Nahr Umr Formation (Figs. 4b, c) were considered by Immenhauser et al. (1999) to have formed within the intra-shelf Bab basin, which, during the Aptian, onlapped to the east and northeast across the Jebal Akhdar area. In this area the formation also contains evidence for a significant influx of terrigenous clastic detritus from the Arabian shield located to the northwest (Immenhauser et al. 1999). Reworking of these fine clastic sediments during storms, resulted in numerous short-duration hiatuses (Simmons and Hart 1987), with these breaks being marked by bioturbated, iron-stained hardgrounds surfaces with phosphatic nodules (Fig. 4b). The influx of siliclastic debris ceased during the late Albian, with the upper part of the Nahr 
Umr Formation and overlying Natih Formation being dominated once again by carbonate deposition (Immenhauser et al. 1999).

The Natih Formation is interpreted as the alternation of two depositional systems: a flat-bedded, mixed carbonate-clay ramp dominated by benthic foraminifera and a carbonate-dominated ramp to intra-shelf basin transition (van Buchem et al. 2002b); and a carbonate platform lagoonal (back-shoal) sequence of bioclastic packstones and mudstones (containing benthonic foraminifera), which was rimmed by coarse bioclastic shoals or rudist biostromes (Simmons and Hart 1987). The thickly bedded Orbitolina limestones in the lower part of the formation (Members $\mathrm{f}-\mathrm{g}$ ) at Wadi Mi'aidin (Fig. 3) were interpreted by Philip et al. (1995) as recording a marine transgression across the outer part of this shelf, with Thalassinoides burrows attesting to a shallow water environment. Member $g$ has been interpreted as a late Albian Maximum Flooding Surface, separated from Member g by 2 hardgrounds forming a sequence boundary (van Buchem et al. 2002b). The overlying rudist to peloidal limestones (Member e) were laid down at Wadi Mi'aidin in a high-energy platform margin shoal environment mid ramp setting ranging from just below to well within fair-weather wave base (van Buchem et al. 2002b), and situated close to a radiolitid rudist bioherm to the east (Simmons and Hart 1987). A number of thick, shallowing upward sequences within this part of the formation, record the basinward progradation and significant vertical aggradation of this part of the formation (Philip et al. 1995), which is bound at the top by an erosional sequence boundary near to the top of Member e (van Buchem et al. 2002b). The remainder of the Natih Formation (Members $d-a$ ) is characterised by back-stepping and corresponding deepening of the carbonate platform, recorded by four shallowing upward, fourth order parasequences (Philip et al. 1995). Lateral facies variations towards the top of the formation (Members b-a), from carbonate platform deposits at Wadi Mi'aidin and eastern Jebel Akhdar, to the black oyster-rich basinal facies limestones (Fitri Formation of Philip et al. 1995) between Wadi Nakhr and Wadi Tanuf, characterise this deepening profile, with the eastward onlap of more basinal facies and differential subsidence, followed by uplift, interpreted as tectonically controlled (van Buchem et al. 2002b). This possibly denotes the initial phase of tectonic loading during the formation of the North Oman foredeep during the Turonian. However, Philip et al. (1995) suggested an alternative eustatic origin, corresponding to a Late Cenomanian sea-level rise, for this facies variation.

A similar deepening upwards sequence, comprising wackestones passing up into lime mudstones, occurs within the Natih Formation of the Adam area (Figs. 1 and 2). The presence of planktonic foraminifera and ammonites, however, indicate that this developed into a deeper, more open-marine environment (outer ramp) during the earliest Turonian (van Buchem et al. 2002b). Further westward at Jebal Salakh, this inner shelf sequence passes into an organic-rich intra-shelf basin, the Mishrif Basin, with black shales and limestones with oysters (Philip et al. 1995); i.e. comparable to the Natih Formation to Fitri Formation transition observed in the Jebal Akhdar area. Van Buchem et al. (2002b) and Simmons and Hart (1987) concluded that the westward transition from ramp to a deeper water intra-shelf basin facies developed both during the early Cenomanian and earliest Turonian, with basinal deposits developed just above or around storm wave base, which they estimate at about 30-40 $\mathrm{m}$. The input of terrigenous muds in the upper part of the Natih Formation, possibly supplied from the Arabian Shield and Huqf Massif, may have occurred in response to marine regression (Philip et al. 1995), with the muds bypassing the platform and entering the basinal areas to the west. Philip et al. (1995) suggested that the cyclic nature of the deeper water facies indicates climatic pulses between more humid and less humid, explaining the terrigenous and carbonate parasequences, respectively.

\section{Carbonate platform margin sedimentary sequence}


Sedimentary rocks interpreted as having been deposited along the carbonate platform margin, variably slope or ramp environments, of the southern side of Neotethys are largely represented by the Permian to Middle Cretaceous Sumeini Group (Table 2). The Sumeini Group comprises five distinct formations; the Ramaq, Jebel Wasa, Maqam, Mayhah and Ausaq Conglomerate formations (Glennie et al. 1974), the latter two recording platform margin sedimentation during the Jurassic to Cretaceous periods.

\section{Mayhah Formation}

In the UAE the Upper Cretaceous (?Coniacian to Campanian) Mayhah Formation (Fig. 2 and Table 2) comprises a monotonous succession of thinly bedded, turbiditic lime-mudstones containing sedimentary structures (current ripple-lamination, hummocky cross-lamination) and large accretionary bedforms consistent with deposition above storm wave base on the upper part of a platform margin slope (Styles et al. 2006). Syn-sedimentary faulting and folding of these limestones, resulting from submarine slumping (Watts 1990; Styles et al. 2006), records the increasingly unstable nature of the continental margin.

In northern Oman, the Mayhah Formation ranges from Early Jurassic to Early Cretaceous (Barremian-Aptian) in age (Glennie et al. 1974) (Table 2). At its type locality at Jebal Sumeini (Figs. 1,5 and $6 \mathrm{a}, \mathrm{b}$ ) the formation has been divided into four informal members (Glennie et al. 1974; Watts and Garrison 1986):

- Member A (c. $400 \mathrm{~m}$ thick) comprising thickly bedded (up to $3 \mathrm{~m}$ thick) calcirudites, interpreted as debris flows or channel-lag deposits, with the interbedded thickening and thinning upwards packages of thinly bedded, variably bioturbated micritic limestone (Fig. 6a) regarded as by-pass slope deposits (Watts 1990). The micritic limestones appear to be deposited below storm wave-base, suggesting an outer ramp setting. In the upper part of the member, cross-laminated peloidal calcarenites preserve starved and climbing ripples, possibly recording reworking or deposition by bottom currents (contourites). The periodic development of channelised conglomeratic beds within this environment may have occurred randomly on an aggradational slope (Watts and Garrison 1986), or have been triggered by the oversteepening and seismicity along the faulted platform margin (Watts 1990);

- The siliceous sediments dominating Member B (19 m thick) have the appearance of silicified graded limestone-mudstone couplets (Figs. 5 and 6b), deposited as distal turbidites or contourites (c.f. Watts and Garrison 1986). However, the reported presence of radiolaria (Glennie et al. 1974) indicates that at least some of the chert is primary. This siliceous member has been interpreted as starved slope deposits associated with a transgressive event caused by a major eustatic sea level rise that drowned the outer part of the Arabian carbonate platform (Watts 1990; Watts and Blome 1990). Watts (1990) suggested that deposition occurred below the Carbonate Compensation Depth (CCD). However, in both the Jebal Sumeini and Qumayrah areas, the presence of calcareous cherts or silicified radiolarian calcilutites, indicates that deposition may have occurred above CCD. The presence of dolomitic limestones near the top of the member passing upwards into swaley bedded grainstones, indicates that its deposition may have been at, or above, storm wave base. The succession, from the base of Member A to the top of Member B has the appearance of an upward fining sequence, with more proximal slope deposits at the base and lower energy distal slope deposits towards the top (Fig. 5), potentially recording a transgressive systems tract. In marked contrast, Watts and Garrison (1986) proposed an upward-shallowing for this succession at Jebal Sumeini; 
- The clast-supported megabreccia that dominates Member C (up to $190 \mathrm{~m}$ thick) possesses a matrix rich in angular chert fragments (Fig. 6b), and contains large blocks (up to $40 \mathrm{~m}$ diameter) derived from the Upper Triassic Jebel Wasa Formation reefal facies, as well as the underlying Mayhah Formation (members A and B). The clast-supported nature of the conglomerates suggests they are not the product of debris flows, but represent avalanche deposits which formed due to the collapse of the carbonate platform (Watts and Garrison 1986);

- Member D (c. $45 \mathrm{~m}$ thick), at Jebal Sumeini, is a variable sequence of thinly bedded grainstones, with ooidal, bioclastic and lithoclastic grainstones, calcirudites, calcareous mudstones and rare radiolarian chert, interpreted as a retrograding slope apron (Watts and Garrison 1986). In the Qumayrah area, however, Watts and Blome (1990) interpret the thinbedded argillaceous calcilutites assigned to Member $\mathrm{D}$, as recording a return to ramp deposition. Slump-folded beds and intraformational calcirudites at the top of the succession in this area denote the steepening of the slope in advance of deposition of the Aruma Group (Fig. 2).

The Mayhah Formation in both the Jebal Sumeini and Qumayrah areas (Figs. 1 and 2) has been interpreted as a thick apron of lower slope limestones along an east-facing, block-faulted platform margin (Watts and Garrison 1986; Watts and Blome 1990). The conglomerate-filled channels transported debris derived from the platform margin reef facies and slope deposits, deeper into the basin (Watts and Garrison 1986; Watts 1990). This suggests that the upper carbonate slope was erosional, with either gulleys in the upper slope or an erosional escarpment passing basinward into a gullied slope (Watts 1990). There is a significant facies change within the Mayhah Formation at Jebal Sumeini, from calcirudite-rich at its type locality in the north, to a more thinly bedded slope facies capped by conglomerate some $15 \mathrm{~km}$ to the south; the latter more typical of the Mayhah Formation seen to the north in the UAE. Watts and Garrison (1986) suggested that at its type locality, the Mayhah Formation represents the lower accretionary portion of a gullied slope, whereas the southern section is an upper bypass area on this slope. This does not, however, explain the comparative rarity of the calcirudite facies within the formation as a whole. It is perhaps more likely that the northern part of Jebal Sumeini sequence represents the axis of an incised channel filled by coarse calciclastic material, whereas the slopes to both the north and south of this channel system were associated with background deposition of micritic limestone.

\section{Ausaq Conglomerate Formation}

The Ausaq Conglomerate Formation (Figs. 2 and 6c) only occurs within the Dibba Zone where it mainly consists of poorly bedded, northerly derived, boulder-grade calcirudites containing clasts derived from the underlying Permian to Lower Cretaceous platform carbonate succession. Locally abundant coral debris is believed to be sourced from small reef build-ups that formed along the platform margin. The formation disconformably overlies, and locally interdigitates with the Mayhah Formation and is interpreted as recording the development of major channels that fed coarse detritus from the carbonate shelf onto the lower slope of the platform during the Cenomanian to Campanian (Styles et al. 2006). Deposition of the Ausaq Conglomearte Formation is thought to have accompanied faulting along the eastern and southern margin of the carbonate platform, with the calcirudites interpreted as channelised debris flows deposited adjacent to these inferred south-westnorth-east-trending syn-sedimentary faults. The Batha Mahani Fault System, which forms the northern margin of the Dibba Zone, is thought to represent the surface expression of one of these reactivated platform margin faults. 


\section{Outer platform margin to basin sedimentary sequence}

The sedimentary sequence deposited on the platform outer ramp to basin environments has largely been included within the Hamrat Duru Group (Glennie et al. 1974; Robertson et al. 1990a, b; Styles et al. 2006) and Wahrah Formation (Glennie et al. 1974). Regionally this sequence is difficult to divide as it consists of lithologically similar successions of variably silicified calcarenites, siliceous mudstones and silicified carbonate mudstones with minor amounts of calcirudite. However, a lithostratigraphy can be recognised locally and is summarised in Table 3. A precise correlation between these units is uncertain as there are no unequivocal biostratigraphical markers. Furthermore, this allochthonous sequence is repeated by thrusting and folding associated with the emplacement of the Oman-UAE ophiolite.

\section{Guwayza Formation}

The Guwayza Formation (Fig. 2) crops out in the Hamrat Duru range of hills in Oman (Glennie et al. 1974; Wilson 2000) where it comprises a lower unit of medium-grained, parallel and cross-lamination sandstones and sandy calcarenites (Fig. 7a), overlain by a sequence of ooidal to peloidal calcarenites, which typically contain convolute lamination (Fig. 7b), interbedded with silicified mudstone. The calcarenites are thought to be outer ramp carbonate turbidites, with widespread soft-sediment deformation suggesting deposition on unstable slopes, with some beds being laid down in gullies and canyons dissecting the margin.

\section{Wahrah Formation}

The mudstone and radiolarian chert-dominated Wahrah Formation (Figs. 7c and 8a; Table 3) of the Hamrat Duru range is interpreted as being deposited in a deep-marine setting punctuated by periodic deposition of thin turbidite calcarenites (cf. Glennie et al. 1974). The overall volume of radiolarian chert within the formation appears to be much less than reported by Glennie et al. (1974). Parts of the succession are lithologically and sedimentologically similar to the more distal turbidites (Fig. 8a) present within the Nayid and Sid'r Chert formations, and, although there is no confirmed correlation, biostratigraphically the Wahrah and Sid'r Chert formations are approximately coeval (Fig. 2).

\section{Sid'r Chert Formation}

The siliceous mudstone and radiolarian chert-dominated Sid'r Chert Formation (Fig. 8b; Table 3) of the Dibba Zone and Hamrat Duru range has been interpreted as deep-marine in origin (Glennie et al. 1974; Styles et al. 2006). The formation contains coarsening and fining-upward, turbiditic limestone sequences (Fig. 8b) that are thought to record the onset and waning of distal turbidite deposition, possibly as individual isolated lobes. The intervening chert-dominated sequences are indicative of prolonged periods with relatively little clastic deposition. Coarse grained, massive calcirudites, some reverse graded, within the Sid'r Chert Formation of the Dibba Zone are interpreted as mass flow deposits formed in an outer carbonate ramp setting. There has been an assumption that the Dhera and Dibba limestone formations overlie the Sid'r Chert Formation (Glennie et al. 1974; Styles et al. 2006), although no clear superposition is exposed, and the contacts between the units have been strongly modified during later thrusting. Consequently, it is uncertain whether the turbiditic limestones of the Sid'r Chert Formation represent a distal, basin-ward extension of the same fan system responsible for the deposition of the much thicker limestone dominated sequences. 


\section{Nayid Formation}

At Jebal Sumeini, the Nayid Formation largely comprises a sequence of thin platy bedded calcareous mudstones and calcarenites (Table 3). Lenticular (channelised) beds of calcirudite contain intraformational limestone clasts (Fig. 7d), demonstrating localised uplift and penecontemporaneous erosion. The clasts are largely unrounded (suggesting limited transport) and exhibit little evidence of soft-sediment deformation indicating they were lithified prior to reworking, presumably during very early diagenesis close to, or at, the seafloor. Basalt clasts within the coarse calcirudites at the base of the formation may be derived from a penecontemporaneous volcanic source. The cement within the calcirudites and interbedded calcarenites is largely composed of carbonate (including dolomite) indicating that cementation probably occurred above the Carbonate Compensation Depth (CCD).

Further south, in the Hamrat Duru range of hills, the Nayid Formation consists of rhythmically bedded, turbiditic calcarenites with calcareous mudstone and calcirudite interbeds (Fig. 7e and 9). The increase in bed thickness in this area is thought to reflect deposition within a more proximal turbidite fan setting, although the occurrence of the trace fossil Paleodictyon (Fig. 9c) is more indicative of relatively deepwater (Seilacher 1967, 1978; Crimes 1975; Bason et al. 1978). Thickening and coarsening upward cycles ( 2 to $10 \mathrm{~m}$ thick) are interpreted as individual fan lobes, with thick-bedded calcirudites and calcarenites displaying markedly erosive bases (Fig. 9a) representing the infill of major submarine channels. Thinning and fining upwards sequences may indicate either the gradual abandonment of a fan lobe, or the abandonment and infill of submarine channels developed on the surface of the fan. The calcarenites are lithoclastic and peloidal, and locally contain ooliths; the latter indicating that high energy, shallow marine detritus was being transported into the relatively deeper parts of the shelf slope. Bioclastic debris in these beds was largely derived from the Lower to Middle Cretaceous Thamama and Wasia groups, with the calcirudites also containing Permian to Triassic reef-derived detritus (Glennie et al. 1974).

\section{Dhera and Dibba limestone formations}

The Dhera Limestone Formation (Figs. 2 and 10; Table 3) crops in both the Dibba and Hatta zones of the UAE, and Jebal Sumeini and Dehra areas of northern Oman, where it comprises a heterogeneously deformed (folded, thrusted), well-bedded, variably silicified turbiditic calcarenites and calcirudites (Fig. 11) (Glennie et al. 1974; Styles et al. 2006). In all these areas, the formation also contains relatively thick (30-50 m) units of siliceous mudstone and radiolarian chert (Fig. 11a). The upwards increase in the number and thickness of limestone beds within these chert-dominated units is interpreted as recording a change from a starved basinal sequence into a turbidite dominated environment, corresponding to an increase in the supply of carbonate detritus into the ocean. Coarsening and thickening upward cycles within the calcarenite dominated sequences (see Fig. 10) record the progradation of individual turbidite fan lobes into the deeper mud-dominated parts of the basin. Smaller scale thinning and fining upwards cycles may represent either channel-fill sequences, developed on the surface of the turbidite fan, or periods of waning turbidite deposition prior to fanlobe abandonment. The calcirudites (Fig. 11b) were probably deposited as channelised mass flow deposits which flowed over the surface of these lobes. The thicker units of very coarse calcirudite probably represent larger submarine channels or canyon deposits. The presence of load structures and soft-sediment deformation in the finer grained limestone beds, large symmetrical and asymmetrical ripples and climbing ripple-drift lamination in coarse-grained calcarenites, are all indicative of a high rate of sedimentation. Thicker beds of calcarenite are typically structureless and probably represent amalgamated turbidite flows. The coarsening upward cycles apparently increase in thickness towards the top of the succession, potentially representing the progradation of a more proximal fan 
environment, supported by an overall upward increase in calcirudite. Ichnofauna, well-preserved in the Jebal Sumeini and Jebal Dhera areas (Figs. 11d and e), indicate deposition on a distal slope (Zoophycos ichnofacies) to basin (Nereites ichnofacies) setting (Seilacher 1967, 1978; Crimes 1975; Bason et al. 1978).

The Dhera Limestone Formation successions in both the UAE and Oman are similar and may represent deposition within a single turbidite fan system, with variations in the scale of coarsening and thickening upward cycles and the proportion of calcirudites reflecting deposition in different parts of this fan system, which fed clastic carbonate detritus into the deeper parts of Neotethys. The lithologically similar Dibba Limestone Formation (see Table 3), which only occurs within the Dibba Zone of the UAE, comprises a relatively thickly bedded sequence of turbiditic calcarenites and calcirudites, interpreted as recording deposition within a more proximal to medial environment within this same overall fan system (Glennie et al. 1974; Robertson et al. 1990a,b; Styles et al. 2006). Calcarenites in both the Dibba and Dhera limestone formations locally contain a 'swaley', undulating bedding or cross-bedding reminiscent of hummocky cross-stratification, potentially indicating deposition at a much shallower depth than previously thought, possibly above storm wave base.

The source of the carbonate clastic debris in the Dhera and Dibba formation turbidites includes late Carboniferous to Permian, Jurassic, and Middle Cretaceous strata. Common ooids and oolitic lithic fragments indicate reworking from a shallower water shelf high energy environment. In addition to the carbonate clasts, minor amounts of siliciclastic sedimentary, metamorphic and chloritised volcanic lithic clasts occur, along with monocrystalline detrital quartz grains ( $\leq 0.5 \mathrm{~mm}$ in diameter). These are presumed to be derived from the Arabian continental landmass, although it is possible that the volcanic detritus may be from penecontemporaneous volcanism within the basin. The provenance data suggest that during deposition of the Dhera Limestone, in Early Cretaceous time, the previously stable carbonate platform had begun to destabilise with associated faulting locally exposing the older parts of the Hajar Supergroup. Importantly, no lithic clastic (quartzose, sedimentary, metamorphic) or volcanic detritus has been reported within the contemporary Thamama and Wasia group limestonedominated successions (see Table 1), suggesting that the continental-derived sediment supplied to Dhera Limestone fan was bypassing large areas of the carbonate shelf.

\section{Basinal sedimentary and volcanic rocks}

Sedimentation within basinal part of the Neotethys Ocean is largely represented by a condensed sequence of radiolarian cherts and siliceous mudstones, represented mainly by the Triassic to ?Lower Cretaceous Shamal Chert Formation of the Dibba and Hatta zones of UAE and in Oman (Table 4). Locally, interbedded volcanic rocks, including the Hatta and Dibba volcanic formations, indicate episodes of mid Cretaceous alkaline to locally tholeiitic within-plate basaltic volcanism (Robertson et al. 1990a, b; Styles et al. 2006). The chert-dominated succession of the Shamal Chert Formation has traditionally been interpreted as deepwater pelagic facies deposited below CCD (see below). The association of a chert mélange with the basaltic volcanic rocks in the Dibba and Hatta zones suggests that mélange generation may have occurred due to slumping in response to volcanic related seismic activity within Neotethys.

\section{Syn- and post-obduction foreland basin deposits}


The sedimentary succession deposited within Neotethys during and immediately following the obduction of the Oman-UAE ophiolite records the breakup of the carbonate platform, and the development of a Late Cretaceous foredeep due to a flexural bulge, associated with crustal loading during ophiolite obduction, which migrated in a westerly direction across the pre-existing platform. These deposits are mainly referred to as the Aruma Group, which includes the upper part of the carbonate platform sequence, platform edge debris flow conglomerates, carbonate turbidites, pelagic lime-mudstones, siliceous mudstones and cherts, and olistostromic mélanges. In the north of the UAE, the group is dominated by the Muti Formation, which in the Dibba Zone, consists of the Qumayrah Limestone and Mudstone and Riyamah Mudstone members (Fig 2; Table 5). However, in the southern part of the Dibba Zone the group also includes the Kub Mélange and Wadi Sanah Mélange formations, as well as the Al Rams Mélange Formation exposed further to the north (Styles et al. 2006). In the southern UAE, the upper part of the Aruma Group is represented by the conglomerates of the Qahlah Formation and shallow-water limestones of the Simsima Formation (see Styles et al. 2006). These strata record the earliest post-obduction deposition within a second foredeep that culminated during Paleogene time and which is, therefore, beyond the scope of this paper. Further to the south, in northern Oman, the Aruma Group is represented by the Qumayrah Limestone and Mudstone Member of the Muti Formation and the Muti Formation of Jebal Akhdar (Fig. 2).

\section{Muti Formation}

At its type area in Wadi Mi'aidin (Figs. 3, 4c and 12) (Glennie et al. 1974), the Muti Formation is informally divided into two units:

- A lower unit dominated by a sequence of packstones, wackestones and mudstones with ferruginous and phosphatic deposits, interpreted by Robertson (1987) as representing a shallow shoal and bioclastic bank setting. The ferruginous horizons denote hardgrounds within this sequence, with current-winnowed lag deposits forming during these breaks in sedimentation. An upward increase in the proportion and thickness of cross-bedded grainstones, give an overall appearance of a shallowing-upward succession with the grainstones representing shallow marine shoals. Coniacian-Santonian radiolarian and Globotruncana fauna have been recorded in this succession (Wilson 2000); and

- An upper unit of coarse-grained and thick-bedded, locally ooidal and cross-bedded, shallowwater high-energy carbonates (Fig. 12b). Clast-supported conglomerates within this unit are apparently imbricated, suggesting deposition by a terrestrial fluvial system. The abundance of large carbonate clasts within the upper part of the Muti Formation (Fig. 12c), probably sourced from the Thamama and Wasia groups, and quartz grains in the lower part, are considered to reflect erosion of the adjacent carbonate platform. Robertson (1987) considered the upper unit of the Muti Formation to document the collapse of this platform. The Muti Formation at Wadi Mi'aidin is now interpreted as inner ramp deposits.

The upper unit in Wadi Mi'aidin was considered by Bechennec et al. (1990) to be the lowermost, and most proximal, tectonic unit of the Hamrat Duru Group (also see Glennie et al. 1974); later assigned to the Guwayza Formation by Rousseau et al. (2005). However, it can be clearly demonstrated that rather than being allochthonous, the upper part of the Muti Formation in Wadi Mi'aidin records continuous deposition, as argued by Wilson (2000). The tectonic boundary was inferred by Glennie et al. (1974) because of an apparent juxtaposition of Jurassic strata above the late Cretaceous Muti Formation. This relationship was proposed in large part because of the presence of radiolarian assemblages of Toarcian to earliest Bathonian age (Rousseau et al. 2005) and because of an apparent similarity with the lithologies present in the Jurassic Guwayza Formation, despite an absence of 
evidence of a tectonic boundary. Wilson (2000) has proposed that the recorded fauna are all reworked, whereas contemporaneous pelagic fauna are absent through dissolution below the CCD in abyssal depths. Although we support the reworked nature of the fauna, the upper unit of the Muti Formation appears to have been deposited above storm wave-base and lacks the deep-water turbidite deposits typical of the Guwayza Formation (Fig. 7a, b).

The uppermost part of the Aruma Group at Wadi Mi'aidin (Fig. 3) rests conformably upon conglomerates of the Muti Formation (at [UTM 0568513 2535643]). This succession shows a rapid transition from high-energy normal-graded, cross-bedded to planar laminated, turbiditic grainstones (up to $1 \mathrm{~m}$ thick) (Fig. 12d), to lower energy, possibly deeper water, lime mudstones (Fig. 12e). The low energy sequence is punctuated by intermittent influxes of grainstones, presumably from storm reworking and resedimentation. This interval has previously been interpreted as the Sid'r Chert Formation (Bechennec et al. 1990, Wilson 2000), although association with the late Cretaceous Riyamah Mudstone Member of the Muti Formation (see below) may be a more suitable interpretation. The apparent deepening of the succession may reflect tectonic loading and development of the foredeep basin.

The lowermost part of the Qumayrah Limestone and Mudstone Member, in the area around Qumayrah (Oman), comprises silicified, pelagic mudstones with radiolarians (Figs. 13 and 14a) interpreted as representing pelagic deposition below the CCD. Thin turbiditic grainstone interbeds (Fig. 14a), however, are less affected by dissolution below the CCD (c.f. Watts and Blome 1990). Thicker beds of calcirudite and cross-laminated ooidal and bioclastic grainstone (Fig. 14b) present within this deepwater succession were derived from the uplifted platform margin and local rudist banks (Watts and Blome 1990). A thick lenticular unit of synorogenic megabreccia was interpreted by Watts and Blome (1990) to indicate erosion of adjacent anticlinal highs. This tectonic instability increased during the deposition of the upper part of the Qumayrah Limestone and Mudstone Member, with a thick development of mudstone-rich olistostromic deposits containing clasts (up to $1 \mathrm{~m}$ ) of mudstone and calcirudite (Fig. 14c). These megabreccias and associated calciclastic sediments are interpreted as recording gravitational instabilities associated with the collapse of the carbonate platform margin (Watts 1990).

In the Dibba Zone, the Qumayrah Limestone and Mudstone Member comprises a sequence of calcareous to siliceous mudstones containing thin to thick beds (up to $3 \mathrm{~m}$ ) of turbiditic calcarenite and minor calcirudite. The finer grained limestones and mudstones locally preserve deepwater Zoophycos to Nereites ichnofacies trace fossils (including Paleodictyon and Nereites). Although the member was deposited in a basinal setting, it locally contains interbeds of a fine- to medium-grained oolitic and peloidal calcarenite; leading to its interpretation as an outer ramp facies. The deeply weathered siliceous mudstone-dominated Riyamah Mudstone Member (Table 5) contains occasional interbeds of radiolarian chert and turbiditic calcarenite and lenticular conglomerate bodies interpreted as channel-fill deposits.

In the northern UAE, small outcrops of Muti Formation pelagic lime mudstones are interpreted as recording a marine flooding event that submerged the underlying carbonate platform succession and the established basinal sedimentation within the Aruma Basin across the entire area now occupied by the Musandam Peninsula. In the Dibba Zone, the formation was deposited in a carbonate outer ramp setting, below storm wave base, with calcarenite and calcirudites within the mudstone-dominated Riyamah Mudstone Member being interpreted as channel-fill deposits, with a background deposition apparently at, or below the CCD of pelagic siliceous mudstone and radiolarian chert (Table 5). The Riyamah Mudstone Member of the Dibba Zone is the distal component of a broad ramp structure 
developed from the south. This deepwater facies prograded northwards as the steep, fault controlled margin of the carbonate shelf slope, marked by the Ausaq Conglomerate Formation, progressively collapsed. No palaeocurrent data is currently available to establish whether the channel-fill deposits within the Riyamah Mudstone Member were derived from the this faulted margin, or part of the broad ramp system developed to the south.

\section{CORRELATION OF MAJOR UNCONFORMITIES WITHIN THE CARBONATE PLATFORM SUCCESSION}

Three major unconformities are recognised within the carbonate platform succession of the Musandam Peninsula and Jebal Akhdar regions, these are located at the base of the Thamama, Wasia and Aruma groups. Not only do the unconformities define these lithostratigraphic group boundaries, but they also establish a framework for correlating regional tectonic events and major eustatic sealevel changes. No expression of these unconformities, either as breaks in sedimentation or marked facies changes, have been recognised on the platform slope or in basinal setting.

\section{Base Thamama Group (Late Jurassic) unconformity}

In the UAE, uplift during the Tithonian gave rise to an end Jurassic unconformity at the top of the gently folded Musandam Group. Stratigraphical relationships displayed between the Musandam and overlying Thamama group, indicate that as much as $300 \mathrm{~m}$ of Musandam Group may have been removed by erosion. The composition of the conglomerates (probably of Berriasian age) at the base of the Thamama Group indicate that this erosion was, at least in part, penecontemporaneous with the deposition of the group. Low relative global sea-levels during the Early Cretaceous (see Fig. 2), may in part account for the penecontemporaneous reworking of the Thamama Group. Volcanic detritus intermixed with platform-derived carbonate material present within the time-equivalent outer ramp succession of the Sid'r Chert Formation in the Dibba Zone (Styles et al. 2006) suggests that the period of instability that resulted in the unconformity may have been accompanied by localised basaltic volcanism. In the platform margin of northern Oman, deposition of the Mayhah Formation continued apparently uninterrupted throughout the Jurassic and Early Cretaceous.

Rousseau et al. (2005) interpreted the stratal termination pattern of the Jurassic Sahtan Group in the Jebal Akhdar area as a widespread, post-depositional, planar truncation surface which cuts down stratigraphy to the east (estimated depth of erosion $43 \mathrm{~m}$ ). In Wadi Mi'aidin, these authors recorded a syndepositional thinning of the Middle Jurassic (lowermost Callovian to Tithonian, Fig. 2) succession toward the east. Above the unconformity, the Rayda Formation (Fig. 2) is transgressive, overlapping this erosional surface towards the west, with the oldest deposits in the east being Tithonian in age, and late Berriasian at Wadi Mi'aidin further to the west (Rousseau et al. 2005).

\section{Base Wasia Group (Aptian) unconformity}

In the UAE the base of the Wasia Group is marked by a sharply defined, gently undulating, planar disconformity with many burrows into the underlying Thamama Group. At Wadi Mi'aidin, the upper part of the Shuaiba Formation (Kahmah Group, Table 1) is absent as a result of erosion at the base of the Wasia Group (van Buchem et al. 2002a). This unconformity represents a break in sedimentation 
from mid to late Aptian times (Kennedy and Simmons 1991) and was interpreted by van Buchem et al. (2002a) as recording a major eustatic fall (c. $50 \mathrm{~m}$ ). However, Immenhauser et al. (1999) concluded that the unconformity may also, at least in part, be attributed to large-scale regional tilting. The overlying Nahr Umr Formation contains evidence of repeated subaerial exposure and nondeposition. In the Nakhl area of northeastern Jebal Akhdar, in the narrow fault-bounded platform margin, the unconformity is seen as a subaerial exposure surface at the base of the platform carbonate Al Hassanat Formation, resting upon Barremian to Late Aptian basinal to slope facies of the Salil Formation (Masse et al. 1997, 1998). An unconformity within the later Natih Formation (near to the top of Member e) being equated with a Mid Cenomanian regressive event recognised across Neotethys (Philip et al. 1995; van Buchem et al. 2002b), suggesting that sea-level fall was the primary control interrupting sedimentation in the Jebal Akhdar area. However, this time interval equates with deposition of the Qumayrah Limestone and Mudstone Member at Qumayrah, which comparatively deepwater sedimentation contains no evidence of such an unconformity.

\section{Base Aruma Group (Turonian) unconformity}

In the Dibba Zone of the northeastern UAE, the Coniacian to Santonian Ausaq Conglomerate Formation directly overlies the Thamama Group, but elsewhere it rests with angular unconformity on the parts of both the Musandam and Ruus al Jibal groups (Styles et al. 2006). In northern Oman, the unconformity at the base of the Aruma Group was interpreted by Robertson (1987) as recording the erosion of a flexural bulge during late Cenomanian to Turonian times, and is responsible for the removal of the deeper water Turonian sediments of the top of the Natih Formation in Wadi Mi'aidin (Philip et al. 1995). Clasts within the limestones from the uppermost part of the Muti Formation were derived from all levels of the platform sequence, down to strata of Permian age, highlighting the depth of erosion associated with this regional low-angle unconformity. The unconformity results in the Muti Formation resting on progressively older strata to the north of the Jebal Akhdar Massif, down to the Triassic Mahil Formation (Glennie et al. 1974; Robertson 1987).

\section{CHERT DEPOSITION AND PALAEO WATER DEPTH WITHIN THE NEOTETHYS OCEAN}

The radiolarian chert-dominated sequences (e.g. Shamal Chert, Sid'r Chert and Wahrah formations) have provided the main evidence for water depth within the Neotethys Ocean. These sequences have previously been interpreted as deepwater pelagic facies deposited below the CCD (Glennie et al. 1974; Lippard et al. 1982; Graham 1980a, b; Searle et al.1983; Bechennec et al. 1990; Robertson et al. 1990a, b), with this assumption influencing all previously published palaeoreconstructions. Consequently, the southern margin of Neotethys was thought to have been marked by a pronounced shelf-slope break and steeply inclined continental slope, passing down into a deep ocean floor well below the CCD (for example see figs. 8.3.1 and 8.5.2 to 8.5.4 of Glennie et al. 1974; fig. 3 of Searle et al. 1983; fig. 2.7 of Lippard et al. 1986; figs. 6 to 9 of Robertson and Searle 1990; fig. 5 of Robertson et al. 1990). The condensed radiolarian chert sequences of the UAE and Oman form part of an extensive pelagic lithofacies (Bernoulli and Jenkyns 1974; Jenkyns 1986; Watts and Garrison 1986; Santantoniao 1994; Gill et al. 2004) that represent long intervals in the rifting and subsidence history in which very little clastic sediment was being supplied to the deeper parts of the ocean. 
The sedimentary sequences present on the carbonate platform contain evidence of water depth wellconstrained by reference to modern analogues, such as the Bahamas or the Persian Gulf, allowing a distinction to be made between deposits interpreted as having been laid down between 0.5 to $5 \mathrm{~m}$ depth (see Gill et al. 2006 and references therein). In contrast, palaeobathymetric estimates for ancient pelagic deposits are typically difficult to determine directly, as they rely on either variably preserved sedimentary features, ichnofacies or derived fossils, or inferences based upon subsidence curves (e.g. cooling ocean crust curves of Parsons and Sclater 1977) and/or the depth of ancient carbonate dissolution surfaces based on modern depth figures (see Bosellini and Winterer 1975; Bernoulli et al. 1979; Winterer and Bosellini 1981; Jenkyns and Winterer 1982). In the case of the Tethyan Jurassic to Cretaceous chert-dominated sequences, estimates of water depth are largely based upon a model (Bosellini and Winterer 1975) developed from the selective dissolution of aragonitic (ammonite shells) and calcitic (aptychi, belemnite rostra) skeletons in Mesozoic deposits (Hollmann 1964; Garrison and Fischer 1969). The resultant figures vary by an order of magnitude. Geochemical comparisons between bedded radiolarian cherts in accretionary complexes and modern deep-marine sediments (Matsuda and Isozaki 1991) have supported a model of deposition on the open ocean floor and subsequent accretion along the continental margin. However, where reliable palaeodepth estimates and palaeoenvironmental constraints do occur, they can indicate a depositional setting for pelagic sediments for which there is no modern analogue. For example, Stow et al. (1996) were able to demonstrate that the pelagic Upper Cretaceous Chalk of northern Europe, which contains abundant silica in the form of flint, was deposited on a continental shelf with water depths as shallow as $50 \mathrm{~m}$. Kametaka et al. (2005) and Takebe et al. (2007) describe a radiolarian chert sequence, the Middle Permian Gufeng Formation on the north-eastern Yangtze platform in China, that was deposited on a continental shelf under suboxic-anoxic conditions caused by organic matter produced during upwelling; the latter possibly also leading to high radiolarian productivity. They conclude that such shelf-type radiolarian cherts are deposited in poorly aerated restricted basins, or in an oxygenminimum zone.

Significance has also been placed upon the presence of certain ichnofauna associated with Zoophycos and Nereites ichnofacies (see Figs. 9c and 11d,e), trace fossils considered to be indicative of deposition within a deepwater slope and basinal setting, respectively (Seilacher 1967). Typical ichnofauna of the Zoophycos ichnofacies include Zoophycos, Cosmorhaphe and Planolites, found in the turbiditic formations of the Hamrat Duru Group, and additionally Helminthopsis and Phycosiphon. Zoophycos has a broad palaeobathymetric range and the significance of this ichnofacies has been interpreted as indicating lowered oxygen levels associated with organic debris accumulation in quietwater settings (Seilacher 1978). Although such conditions are common in deepwater slope environments, such ichnofauna can equally occur in shallower water epeiric deposits (Maceachern et al. 2007). The Nereites ichnofacies present within the study area includes Paleodictyon, Chondrites and Nereites (?Helminthoida), with additional Taphrhelminthopsis (Seilacher 1967). The graphoglyptid trace fossil Paleodictyon (see Fig. 9c) is commonly thought to be indicative of a deepmarine environment (Seilacher 1967; Crimes 1975; Bason et al. 1978). However, recent work on Tethyan sequences in Iran suggests that Paleodictyon can be found in a wide bathymetric range including shallow-water storm beds (Fürsich et al. 2007). Despite this, the ichnofacies as an entire community is still considered to reflect basinal conditions and appears largely independent of the presence of turbidite deposits (Maceachern et al. 2007).

Examination of sequences in the UAE (Styles et al. 2006; this study) and northern Oman (this study) has highlighted the fact that there is no unequivocal palaeobathymetric indicators within the Neotethys sequences and we conclude that water depth along its southern margin remains uncertain. 
A number of the chert-dominated sequences either contain, are interbedded with, or pass upwards into, relatively thick sequences of turbiditic limestone, e.g. Dhera Limestone Formation (Fig. 11a), Sid'r Chert Formation (Fig. 8b), Nayid Formation and Qumayrah Limestone and Mudstone (Fig. 13) and Riyamah Mudstone members of the Muti Formation. They all, record the input of carbonate dominated clastic detritus into what has been thought of as relatively deepwater of Neotethys (see Glennie et al. 1974; Robertson et al. 1990a, b; Styles et al. 2006). Styles et al. (2006) argued that the input of significant amounts of carbonate detritus into the deeper parts of the ocean, below the CCD, would have modified sea water chemistry and temporarily switched off carbonate dissolution. Although the thicker limestone turbidite sequences of the Dhera, Dibba and Nayid formations show evidence of penecontemporaneous silicification and thus the potential resetting of sea water chemistry can be inferred, beds of calcarenite also occur within the chert-dominated Shamal and Sid'r chert formations which would probably be insufficient to reset/override carbonate dissolution below the CCD. Another potential problem with this model is that the Dhera and Dibba limestone formations are relatively thin (estimated stratigraphical thicknesses of 300 to $400 \mathrm{~m}$, Table 4), with available biostratigraphical data indicating a potential depositional age range of late Hauterivian to Cenomanian, a period of some 20 to 30 million years. If this age range is correct it may suggest that carbonate clastic sedimentary input into the deeper parts of Neotethys was relatively limited and therefore insufficient to override carbonate dissolution.

The Qumayrah Limestone and Mudstone Member, in the area around Qumayrah (Oman), comprises silicified, pelagic mudstones with radiolarians (Fig. 14a) interpreted as representing pelagic deposition below the CCD. Thin turbiditic grainstone interbeds (Fig. 14b) and thicker beds of calcirudite and oolitic and bioclastic grainstone, however, are less affected by dissolution below the CCD (Watts and Blome 1990). The grainstones are very thin and unlikely to have been buffered from silicification. They also show swaley bedding, suggesting deposition above storm wave base, with this succession potentially representing deposition in a mid-ramp setting within a starved basin, rather than a basinal plan facies formed below the CCD.

The Tithonian to Early Cretaceous radiolarian cherts within the Mayhah Formation at Jebal Sumeini occur within a continuous sequence of carbonate clastic slope deposits (Figs. 5 and 6b). The chert apparently replaces graded limestone-mudstone couplets deposited by distal turbidites or contourites, and occurs above a nearly $400 \mathrm{~m}$ thick upward fining carbonate succession in which secondary silicification is limited to its uppermost part. The overlying calcirudites also lack evidence of secondary silicification and contain abundant chert clasts. This suggests that the rapid influx of thick calcirudite deposits suppressed secondary silicification, potentially supporting the argument for temporary switching off of carbonate dissolution or, alternatively, that the cherts were formed above the CCD. The 'swaley' or undulating bedding reminiscent of hummocky cross-stratification within the Dhera Limestone Formation in the UAE and Oman, and grainstones within the Qumayrah Limestone and Mudstone Member (Fig 14a) of Oman provides an additional water depth indicator, suggesting that deposition of at least part of this turbiditic sequence may have occurred above storm wave base.

Sedimentation along the southern margin of Neotethys was clearly dominated by carbonate production, with very little sediment being supplied into the relatively deeper parts of the ocean, thus potentially allowing chert deposition at much shallower water depths, possibly even on the outer parts of the continental shelf (cf. the Middle Permian Gufeng Formation, Kametaka et al. 2005; Takebe et al. 2007). The condensed, chert-dominated sequences represented by the Shamal and Sid'r chert formations may simply record the fact that the basin was effectively starved (i.e. lacking significant clastic input) allowing chert deposition at much shallower water depths than previously thought. The 
turbiditic limestone formations represent periodic input of carbonate-dominated clastic detritus into this starved basin. The potential for siliceous pelagic sedimentation at much shallower depths within the Neotethys Ocean would explain the relatively 'rapid', progradation/fluctuation from apparently 'deeper' water facies to 'shallower' water facies observed at Qumayrah. These clastic limestone sequences, like the turbiditic limestone formations within the Hamrat Duru Group, are relatively thin (see Table 5) and, therefore, do not record the input of significant amounts of carbonate-dominated clastic sediment prograding into the southern part of Neotethys. If the southern part of Neotethys was starved, with chert deposition occurring at a shallow level within the basin, possibly on the outer parts of the shelf, then it may also mean that the topography of the shelf-slope-basinal margin was more subdued than previously thought, casting doubt upon the steep shelf margin advocated in previous models (Glennie et al. 1974; Searle et al. 1983; Lippard et al. 1986; Robertson and Searle 1990; Robertson et al. 1990). In the starved basin model for the southern margin of Neotethys, chert deposition may have occurred in a mid-ramp (above storm wave base) to outer ramp setting; i.e. at much shallower water depth, potentially in the range of tens to up to $200 \mathrm{~m}$ depth. This more gentle ramp margin morphology appears to have persisted until early to mid-Cretaceous times when the platform margin started to become unstable during ophiolite obduction. The proposed gentle ramp morphology to the southern margin of Neotethys has been incorporated into a series of models illustrating the sedimentary and tectonic evolution of this ocean (see below).

\section{REVISED MODEL FOR THE SEDIMENTARY AND TECTONIC EVOLUTION OF THE SOUTHERN MARGIN OF THE NEOTETHYS OCEAN}

The sedimentary evolution of the southern margin of Neotethys can be divided into three main stages:

- Stage 1 - Initial rifting and formation of the Neotethys Ocean, followed by a prolonged period of stable, passive margin sedimentation which extended from the Permian to Late Jurassic times;

- Stage 2 - Late Jurassic to Early Cretaceous uplift and erosion of the shelf margin, coincident with increased carbonate-clastic sedimentation in the outer ramp, distal slope and basinal areas;

- Stage 3 - Late Cretaceous increased instability, breakup of the platform margin and foreland basin sedimentation accompanying the obduction of the Oman-UAE ophiolite;

The relationships between the carbonate platform to Neotethys deeper water facies (described above) are illustrated in a series of schematic 3D block diagrams and palaeogeographical reconstructions covering five time intervals (Figs. 15 to 21). Care must be taken when reconstructing the original depositional setting of these sedimentary sequences as the relationships between deposits laid down on different parts of the ramp and the basin have been modified by large-scale thrusting and tectonic transport associated with the closure of Neotethys and obduction of the Oman-UAE ophiolite (see Styles et al. 2006 references therein).

\section{Stage 1 - stable passive margin sedimentation}

Carbonate passive margin sedimentation on the southern margin of Neotethys 
Following a period of rifting in the early Mesozoic, the Neotethys Ocean opened between Arabia and several small microcontinents (including Central Iran, Afghanistan and Central Tibet), which had broken off the north-eastern margin of Gondwana, and migrated northeast. Permian to Late Jurassic sedimentation on the passive southern margin of Neotethys in both the UAE and northern Oman was dominated by the formation of the carbonate platform sequences of the Musandam Peninsula and Jebal Akhdar. The carbonate platform remained relatively stable through the Jurassic, enabling accumulation of a thick, monotonous sequence of shallow carbonate ramp deposits represented by the Musandam (UAE) and Sahtan groups (Oman) (Fig. 15). These rhythmically bedded limestones contain transitions from emergent surfaces to low energy, near-shore environments, including tidal mud flats and sabkhas, passing upwards into slightly deeper water, moderate- to high-energy inner ramp environments, through to open marine mid-ramp settings. In the southern part of the Musandam Peninsula, these ramp limestones pass laterally to peloidal grainstones, oncolitic and bioclastic packstones containing coral fragments, deposited close to the platform margin.

Submergence of the platform during the Jurassic resulted in the onlap of "slope" carbonates of the Mayhah Formation over the drowned Triassic reef (Watts and Garrison 1986). In the Jebal Sumeini and Qumayrah areas, the lower part of the Mayhah Formation (Member A) records ramp sedimentation throughout the Jurassic (Fig. 2). At Jebal Sumeini, the formation comprises a thick apron of outer ramp micritic limestones deposited below storm wave-base (Fig. 15). These outer ramp deposits are gullied by calcirudite-filled channels either triggered by oversteepening and seismic activity along the faulted platform margin (Watts 1990) or, alternatively, due to instability on an aggradational slope (Watts and Garrison 1986). The large-scale facies variations within the Mayhah Formation in this area are interpreted as representing the axis of a large, incised channel system which carried coarse calciclastic material into the basin, with the finer grained, background deposition of more thinly bedded, locally turbiditic limestones to the north and south of this system (Fig. 15). Sedimentary structures preserved within the calcarenites suggest that these slope deposits may have been reworked, or, at least in part, deposited by bottom currents (e.g. contourites). In the Qumayrah area, the reworked ooidal calcarenites, calcareous mudstone and calcirudites of the Mayhah Formation represent an outer ramp apron developed along an east-facing block-faulted platform margin (cf. Watts and Blome 1990). To the south, in the Hamrat Duru area, the distal turbidites and deep-marine suspension deposits are attributed to the Guwayza and Wahrah formations.

\section{Basinal sedimentation adjacent to the passive margin carbonate platform}

Basinal sedimentation during the Triassic and Jurassic was dominated by the slow accumulation of thinly bedded radiolarian cherts and siliceous mudstones of the Shamal Chert Formation (Fig. 15). This condensed sequence indicates that the relatively deeper parts of the Neotethys Ocean were essentially starved of clastic sediment input, apart from the infrequent input of minor amounts of carbonate-rich detritus by turbidite flows. Although originally thought of as recording deposition on an abyssal plain (Hudson et al. 1954a, b; Allemann and Peters 1972; Glennie et al. 1974; Robertson et al. 1990a, b; Styles et al. 2006), the absence of unequivocal palaeobathymetric indicators raises the possibility that deposition may have occurred at relatively shallow depths; for example on the upper part of the basin slope, where upwelling currents may have promoted high radiolarian productivity.

Alkaline basaltic volcanic rocks present within the Shamal Chert Formation of the UAE (Styles et al. 2006) and similar chert-dominated sequences in northern Oman (Glennie et al. 1974; Lippard and Rex 1982; Searle and Cooper 1986; Searle et al. 1980) indicate that minor within-plate oceanic volcanism occurred periodically within Neotethys. However, the age of this volcanism remains uncertain due to poor biostratigraphical control. 


\section{Stage 2 - uplift, erosion and instability along the southern margin of Neotethys}

\section{Sedimentation on the carbonate platform}

Stable carbonate platform sedimentation ended with periods of uplift and considerable erosion of the Musandam Platform, probably commencing around Kimmeridgian time with an unconformity at the base of the Thamama Group and a further major break in sedimentation during the mid to late Aptian, marking the base of the Wasia Group (Fig. 2). This period marked the onset of instability along the southern margin of Neotethys during the Early Cretaceous, resulting in increasing clastic carbonate input into the deeper parts of the ocean.

In the UAE, the Berriasian to Aptian Thamama Group records eastward progradation of an outer ramp lime mudstone-dominated succession (Fig. 16), possibly in response to relatively low sea-levels during the Early Cretaceous (Fig. 2). Channels containing metre-scale blocks of inner ramp carbonates are interpreted as deposits of relatively turbid gravity flows which cascaded down the platform ramp (Fig. 16). The highly bioclastic wackestones contain rudist bivalves derived from build-ups formed higher up the ramp. In the Jebal Akhdar area, the lower part of the Thamama Group records the progradation of the upper part of a carbonate ramp system, comprising shallow lagoonal limestones deposited behind an ooidal barrier shoal (Simmons and Hart 1987). The transition from high-energy shallow water deposits (Unit A highstand systems), to low-energy facies with hardgrounds (Unit B lowstand system), passing up into lagoonal deposits (Unit C) within the late Hauterivian to Aptian Kharaib Formation is interpreted as recording a base level rise, occurring at a time of relatively high global sea-level (Fig. 2), presumably reflecting a eustatic driver as opposed to tectonic control. The Aptian Shuaiba Formation in the Jebal Akhdar area records a transition from a restricted inner shelf setting to more open-marine inner shelf environment, with an open-marine highenergy setting located on the outer shelf to the northeast (Fig. 17). At the same time, to the west of the Jebal Akhdar Massif, an organic-rich limestone facies was being deposited within an intra-shelf basin (see Fig. 17b), the Bab Basin of van Buchem et al. (2002a).

The mid to late Aptian disconformity represents a regional break in sedimentation that probably resulted from a combination of uplift and tilting, coupled with globally low sea levels (Fig. 2). It both the Musandam Peninsula and at Wadi Mi'aidin, this disconformity is overlain by shallow water limestones of the Wasia Group, interpreted as having been deposited in a restricted or lagoonal environment presumed to be in an inner shelf setting (Fig. 18). In the UAE, the Wasia Group records an overall shallowing upwards sequence, containing an increasing number of hardgrounds towards the top of the succession. At Jebal Akhdar, the Nahr Umr Formation was deposited within the Bab intrashelf basin, onlapping to the east and northeast during the Aptian (Immenhauser et al. 1999). Northwesterly derived terrigenous clastic detritus, supplied to the Bab Basin during the early to mid Albian, records erosion of the Arabian Shield, probably associated with development of the mid to late Aptian disconformity. This source was cut off, possibly in response to rising global sea-level, during the late Albian when the upper part of the Nahr Umr Formation and overlying Natih Formation in Oman mark a return to carbonate-dominated deposition (Fig. 2).

The Jurassic to Early Cretaceous unconformity present at the base of the Thamama Group is absent in the mid- to outer ramp setting of northern Oman, with the Mayhah Formation recording an uninterrupted transition from platform margin limestones to pelagic cherts (Fig. 2). The radiolarian chert-bearing succession (Member B) within the Mayhah Formation contains swaley cross-bedded 
calcarenites, suggesting that deposition occurred above storm wave-base; i.e. in a mid-ramp setting at a significantly shallower depth than previously thought. This siliceous unit is part of a widely developed chert-rich succession which formed across the mid- to outer ramp to basin setting at this time (see below). At Jebal Sumeini, the base of a thick calcirudite succession (Member C) which overlies the cherts, represents a dramatic change within the basin. During the Aptian and Albian the upper part of the Thamama Group and the Wasia Group indicate deposition within a shallow shelf environment, with evolution of a steep fore-reef slope, possibly adjacent to active fault scarps. The development of these steeper slopes appears to have caused the development of thick talus deposits, possibly accompanied by erosion of the shelf margin (Fig. 18), during a period of gradually rising sealevel (Fig. 2). The upward variation in the composition of these rudites records the progressive unroofing of the tectonically uplifting platform succession.

\section{Sedimentation adjacent to the increasingly unstable platform margin}

The carbonate ramp limestones of the Thamama, Wasia and Sumeini groups are thought to pass south-eastwards into a deeper water succession represented by the Hamrat Duru Group (Figs. 2, 17 and 18). In the UAE, the Berriasian to Valanginian Sid'r Chert Formation is contemporary with the lower part of the Thamama Group (Fig. 2). Pelagic chert and mudstone deposition was periodically interrupted by influxes of turbiditic calcarenites and microconglomerates forming isolated lobes within a relatively distal turbidite fan environment in a generally outer ramp to basinal setting (Fig. 18). The relationship between water depth and the conditions for chert development, and deposition of siliceous mudstone, is a crucial aspect in the determination of regional basin configuration during Cretaceous time in particular. Although both the Sid'r Chert and Wahrah formations have previously been interpreted as having been deposited below the CCD it is possible that they were deposited closer to the platform margin and in much shallower marine environment than previously thought (see earlier discussion). Palaeontological and sedimentological data suggests that the Wahrah Formation may be correlated with either the Sid'r Chert and Mayhah Member B (Fig. 2), or alternatively represent a more distal facies of the Dhera and Nayid formations (Figs. 17 and 18).

Lower Cretaceous chert-rich sequences represent a major transgressive event that drowned the outer ramp and caused a temporary cessation of significant carbonate input. These sediments are thought to have accumulated in the basin and outer ramp during a period of worldwide low sea level (Fig. 2), suggesting that deposition was not caused by eustatically driven drowning of the platform margin, as proposed by Watts (1990), but in response to tectonically induced subsidence. The presence of first cycle basaltic volcanic detritus in mass flow deposits and volcaniclastic sandstones of the Sid'r Chert Formation suggest that deposition was punctuated by basaltic volcanism, perhaps caused by extension and localised thinning of the carbonate platform and adjacent ocean floor in response to the increasing instability of the southern margin of Neotethys.

In the Dibba Zone, the Hamrat Duru Group is dominated by the rhythmically bedded, proximal to distal, turbiditic limestones and subsidiary cherts of the Hauterivian to early Cenomanian Dhera and Dibba Limestone formations. Facies changes within the Dhera Limestone Formation in both the UAE and Oman are consistent with it representing parts of a single carbonate sand-rich fan system which fed limestone dominated detritus into the deeper parts of the Neotethys Ocean (Figs. 17 and 18). Variations in the scale of coarsening and thickening upward cycles, and proportion of calcirudite within the sequence reflect deposition within medial to distal fan environments (Figs. 17 and 18). Small-scale thinning and fining upwards cycles may represent either distributary channel-fill sequences developed upon fan lobes, or record waning turbidite deposition during fan-lobe abandonment. The relatively thickly bedded Dibba Limestone Formation of the Dibba Zone 
represents a more proximal facies within this fan system. In the Hamrat Duru area, the Hamrat Duru Group is dominated by the Barremian to Cenomanian turbiditic limestones of the Nayid Formation, coeval with the Dhera Limestone Formation (Robertson et al. 1990a, b; Styles et al. 2006). The Nayid Formation comprises thickening upwards and coarsening upward cycles recording the development of individual turbidite fan lobes (Fig. 18). Although sedimentologically and lithologically similar to the Dhera Limestone Formation, there is no unequivocal evidence that these formations formed a coalesced fan system, and it seems unlikely there was sufficient debris available to enable such a large, single fan system to develop. Consequently, they are thought to represent two separate fan systems, as illustrated on Fig. 18.

Palaeocurrent data from the turbidites of the Hamrat Duru Group (Glennie et al. 1974; Styles et al. 2006) show a radial pattern of sediment dispersal, with overall palaeoflow directions towards the north, north-east and east (see Figs. 17 and 18; also see fig 8.21 in Glennie et al. 1974). Trace fossils present within both the Nayid and Dhera formations, including Arenicolites U-shaped burrows and more complex Paleodictyon net-like traces (see Fig. 9c), are consistent with Zoophycos to Nereites ichnofacies that are typically equated with deposition in a quiet, relatively deep marine environment. However, presence of hummocky cross-bedding within some turbidite beds suggests local deposition within the range of storm wave-base.

Provenance studies on the Dhera Limestone (Styles et al. 2006) and, to a lesser extent, Nayid formations (Glennie et al. 1974) show that both were derived from a source which included Carboniferous, Permian and Jurassic limestones and, in the case of the Nayid Formation, PermoTriassic reefs. Oolitic limestone clasts present in both formations indicate that sediment was also derived from the shelf margin, possibly bypassing the shelf slope to feed into the basin (Fig. 18). The minor, but significant, terrigenous siliciclastic input in the Dhera Limestone turbidites and early to late Albian carbonate platform sediments of the Nahr Umr Formation (Wasia Group) (Fig. 18) were derived from the same source.

\section{Stage 3 - increased instability, breakup of the platform margin and sedimentation accompanying the obduction of the Oman-UAE ophiolite}

\section{Sedimentation along the foundering carbonate platform margin}

In the UAE, extensional faulting along the northern side of the Dibba Zone during the late Cenomanian to Campanian led to the break-up of the platform and gave rise to deposition of the Ausaq Conglomerate Formation (Fig. 19). These northerly derived debris flows contain clasts derived from the Permian to Lower Cretaceous platform carbonate succession, as well as coral debris sourced from small reef build-ups formed along the faulted platform margin (Fig. 19). The calcirudites disconformably overlie, and locally interdigitate with, the Mayhah Formation; the latter deposited on the upper part of a shelf slope, possibly above storm wave base. Submarine slumping of these marginal slope deposits records the increasingly unstable nature of the continental margin. Comparison with the approximately coeval uppermost part of the Mayhah Formation (Member D) in Jebal Sumeini, indicates that these limestones were deposited by a retrograding slope apron, consistent with the highstand sea-levels during the Cenomanian, and in accord with development of radiolarian chert and siliceous mudstone along the platform margin in the Qumayrah region at this time. 
The Cenomanian Natih Formation (upper Wasia Group) at Wadi Mi'aidin and the eastern part of Jebel Akhdar records the aggradation and progradation of the platform facies. The top of the Wasia Group is locally deeply eroded, and unconformably overlain by the Muti Formation (Aruma Group). Robertson (1987) considered this low-angle unconformity to be Late Cenomanian to Turonian in age, apparently coinciding with a significant regional fall in sea-level (Fig. 2). However, the angular nature of the unconformity indicates a tectonic control and the development of a flexural bulge marginal to a foredeep basin (Robertson 1987), the subsequent subsidence of which provided the source of sediment for much of the Aruma Group. Further to the north, along the western margin of the Musandam peninsula, the Muti Formation was deposited disconformably on a hardground developed on the Wasia Group probably in the early Cenomanian to Turonian (see Styles et al. 2006). The Muti Formation sequence records a transgressive flooding event that led to the establishment of the Aruma Group basin probably across the entire area now occupied by the Musandam Peninsula.

\section{Pelagic sedimentation and oceanic within-plate volcanism within Neotethys}

In the UAE, sedimentation within the distal deeper parts of Neotethys during the Cretaceous is represented by the Shamal Chert Formation. Similar condensed sequences of siliceous pelagic rocks occur also in the Hawasina Window of northern Oman (Glennie et al. 1974; Searle and Cooper 1986). In this part of the succession there is little evidence of the influx of clastic carbonate detritus which accompanied the deposition of the Hamrat Duru Group. However, at the end of the Albian and into the Cenomanian, extrusion of the oceanic within-plate alkaline volcanic rocks of the Hatta Volcanic Formation in the Hatta Zone and the Al Hala Alkaline Volcanic Formation of the Masafi-Ismah Metamorphic Window provides the first clear evidence of a major change in the stability of the deeper parts of ocean basin (see Fig. 20a). Styles et al. (2006) concluded that these basaltic volcanic formations marked a phase of extension and possibly rifting within Neotethys, potentially coinciding with the generation of the early crustal components of the Oman-UAE ophiolite; the latter occurring several hundred kilometres to the east of the continental margin within a back-arc basin setting, rather than at a true mid-ocean ridge (Lippard et al. 1986; Styles et al. 2006 and references therein). Continuing oceanic within-plate volcanic activity, represented by the late Cenomanian to Turonian, predominantly alkaline Dibba Volcanic Formation, may have coincided with break-up of the platform margin and deposition of the lower part of the Aruma Group during this subsidence-induced flooding event.

\section{Syn-obduction sedimentation within the remnant Neotethys}

The geochemistry of the late magmatic sequence within the Oman-UAE ophiolite is interpreted as recording the development of a subduction zone (probably north-east-dipping) within Neotethys during the Cenomanian (see Styles et al. 2006 and references therein). These late intrusions are typically associated with high temperature ductile shear zones, indicating that the formation of the magmas was closely associated with the initiation of ophiolite obduction. Loading of a leading-edge of ocean crust flooring Neotethys by the advancing ophiolite would have resulted in extension and rifting towards the ocean margin, leading to localised volcanism and the progressive collapse of the adjacent carbonate platform and contraction of the ocean. The lower part of the Aruma Group was laid down in this rapidly narrowing ocean basin, located between the foundering carbonate platform margin and the advancing Oman-UAE ophiolite (Fig. 20b).

During obduction, the pelagic sediments of the Shamal Chert Formation and the slope sediments of the Hamrat Duru Group were deformed and progressively incorporated into an imbricate thrust stack developing in front of the advancing ophiolite (Fig. 20b). Instability within the thrust stack, as it 
propagated northwards and westwards, led to the generation of the ?Cenomanian to Turonian (or younger) Kub and Wadi Sanah mélanges which contain olistoliths of variably deformed Dhera Limestone and Shamal Chert formations, Lower Palaeozoic rocks, basaltic volcanic rocks and, in the case of the Wadi Sanah Mélange, large blocks of highly deformed serpentinite. These mélanges were progressively incorporated into the developing imbricate stack. In the Qumayrah region, instability, possibly during the Campanian, led to the development of the mudstone-rich olistostromes (Fig. 14c) in the upper part of the Qumayrah Limestone and Mudstone Member. In the Jebal Akhdar area, with the Aruma Group succession dominated by fluvial or littoral, near shore deposits (Fig. 21). Consequently, the increasingly restricted, deepwater relict of Neotethys is thought to have separated the shallow marine carbonate succession of the Musandam Peninsula (UAE), from a developing shoreface to terrestrial environment located to the south in the Jebal Akhdar area of Oman (Fig. 21). The newly identified autochthonous Aruma Group of the Jebal Akhdar region records a rapid transition from high-energy, possibly turbiditic, limestones to lower energy, potentially deeper water calcareous mudstones, and apparent deepening of the sedimentary during the ?Late Campanian, hence post-obduction of the Oman-UAE ophiolite.

In contrast to the terrestrial to shallow water succession present in the Jebal Akhdar area, The Muti Formation of the Dibba Zone is dominated by the siliceous deepwater facies of the Riyamah Mudstone Member. Along the northern margin of the Dibba Zone, the Riyamah Mudstone Member locally rests conformably upon the Mayhah Formation, recording the progressive collapse of the platform margin and deepening of the basin during the deposition of the Aruma Group (Fig. 21). Further to the northwest, along the front of the Musandam Mountains, the Muti Formation rests directly upon the Wasia Group and consists of a fining upward sequence which records a marine flooding event that submerged the underlying carbonate platform succession and established the relatively deeper water, basinal sedimentation in the early Aruma Basin. In the north-western part of the Dibba Zone, the turbiditic limestones and mudstones of the Qumayrah Limestone and Mudstone Member, which contain Nereites to Zoophycos ichnofacies trace fossils, interdigitate with the basinal siliceous mudstones and radiolarian cherts of the Riyamah Mudstone Member. Although deposited in apparently deeper parts of the remnant Neotethys Ocean basin, the turbiditic limestones within the Muti Formation locally include interbeds of an oolitic and peloidal calcarenite, indicating that sediment was being partially derived from a near-shore, high-energy environment.

\section{CONCLUSIONS}

The concept that the autochthonous, parautochthonous and allochthonous Permian-Cretaceous sequences in the UAE and Oman record the transition from platform, slope to basin sedimentation has been fundamental to the interpretation of the geological history of the region. However, the results of this study have led to a greater appreciation of the sedimentology and depositional setting of the sediments laid down along the northeastern Arabian continental margin during the Jurassic to Cretaceous, allowing a more refined model of Neotethys Ocean basin evolution to be established. This model charts the progressive breakup of the Arabian continental margin and closure of Neotethys during the mid to late Cretaceous and is divided into three main stages:

- Stage 1 - Initial rifting and formation of the Neotethys Ocean, followed by a prolonged period of stable, passive margin sedimentation which extended from the Permian to Late Jurassic times; 
- Stage 2 - Uplift and erosion of the shelf margin during the Late Jurassic to Early Cretaceous, coincident with increased carbonate-clastic sedimentation in the outer ramp, distal slope and basinal areas;

- Stage 3 - Increased instability during the Late Cretaceous leading to the breakup of the platform margin and foreland basin sedimentation accompanying the obduction of the OmanUAE ophiolite;

Data obtained for the upper part of the platform and platform margin to slope successions has revealed significant new information on the form of the basin margin at this important time in the evolution of Neotethys. In particular, the topography of the "shelf"-slope-basinal margin was more subdued than previously thought, casting doubt upon the steep shelf margin advocated in previous models. The thrust-repeated allochthonous sedimentary rocks of the Hamrat Duru Group were deposited on the outer platform margin/lower slope rise to basinal plain, with the Dhera Limestone, Dibba Limestone and Nayid formations representing the dismembered parts of two turbidite fan systems which fed carbonate-rich detritus into deeper parts of the basin. A revaluation of the chertrich sequences has led to the conclusion that these siliceous deposits may not have been laid down on the abyssal plain of Neotethys as previously thought, but may in fact record sedimentation at a much shallower level within a starved ocean basin, possibly in a mid-ramp (above storm wave base) to outer ramp setting. This more gentle ramp margin morphology appears to have persisted until early to midCretaceous times when the platform margin started to become unstable during ophiolite obduction. The change in basin dynamics during the mid-Cretaceous, led to the development of a shallow ramp basin margin in Oman with terrestrial to shallow marine sedimentary rocks interdigitating with red siliceous mudstones; the latter were probably not deepwater in origin. By contrast, the contemporaneous succession in the Dibba Zone of the UAE indicates considerable instability on a steep shelf break. This instability is recorded by the presence of several major olistostrome deposits within the Aruma Group of the UAE which are thought to have been generated in advance of the rapidly obducting Oman-UAE ophiolite.

\section{ACKNOWLEDGEMENTS}

This paper provides the results of work carried out by the British Geological Survey (BGS) for the Mineral Resources Department of the Ministry of Energy, United Arab Emirates under its contract for geological investigations in the Emirates and northern Oman. We wish to thank the Ministry of Energy, (Petroleum \& Minerals Sector, Minerals Department), and especially the Director Mr Saleh Al Mahmoudi, for support and encouragement at every stage of the work. We also acknowledge the help of Mr Khalid Ali Al-Hosani, Deputy Director, and Mr Abdullah Gahnoog, Technical Adviser. Ken Glennie, J.R.F Borgomano and one anonymous are thanked for their constructive reviews. This paper is published with the permission of the Executive Director, British Geological Survey (National Environmental Research Council) and the Ministry of Energy (Petroleum \& Minerals Sector, Minerals Department), Federal Government of the United Arab Emirates.

\section{References}

Allemann F, Peters T (1972) The Ophiolite-Radiolarite Belt of North-Oman Mountains. Eclogae Geologica Helvetica 65: 657-697. 
Alsharhan AS, Nairn AEM (1997) Sedimentary Basins and Petroleum Geology of the Middle East. Elsevier, Amsterdam.

Bason PB, Chamberlain CK, Frey RW, Howard JD, Seilacher A, Warme JE (1978) Trace fossil concepts SEPM short course No. 5. Oklahoma City 1978, Society of Economic Paleontologists and Mineralogists pp 181.

Béchennec F, Le Métour J, Rabu D, Bourdillon de Grissac, C, De Wever P, Beurrier M, Villey M (1990) The Hawasina Nappes: stratigraphy, paleogeography and structural evolution of a fragment of the south-Tethyan passive continental margin. In Robertson AHF, Searle MP, Ries AC (eds) The Geology and Tectonics of the Oman Region. Geological Society, London, Special Publication 49: 213-223

Bernoulli D, Kalin O, Patacca E (1979) A sunken continental margin of the Mesozoic Tethys: the northern and central Apennines. Symposium "Sedimentation Jurassique W Europeen'. A.S.F. Special Publication 1: 197-210.

Bernoulli D, Jenkyns H (1974) Alpine, Mediterranean and central Atlantic Mesozoic facies in relation to the early evolution of the Tethys. In Dott Jr RH, Shaver RH (eds) Modern and Ancient Geosynclinal Sedimentation. Special Publication, Society of Economic Paleontologists and Mineralogists 19: 129-160

Biehler J, Chevalier C, Ricateau R (1975) Carte géologique de la peninsula de Musandam. Ministry of Petroleum and Minerals, Sultanate of Oman, Muscat.

Borgomano J, Masse JP, Al Maskiry S (2002) The lower Aptian Shuaiba carbonate outcrops in Jebel Akhdar, northern Oman: Impact on static modelling for Shuaiba petroleum reservoirs. AAPG Bulletin, 86: 1513-1529.

Bosellini, A, Winterer E (1975) Pelagic limestone and radiolarite of the Tethyan Mesozoic: a genetic model. Geology 3: 279-282.

Burchette (1993) Mishrif Formation (Cenomanian-Turonian), Southern Arabian Gulf: Carbonate Platform growth along a cratonic basin margin. In Cretaceous Carbonate Platforms. AAPG Special Volume M 56: 185-199

Crimes P (1975) The stratigraphical significance of trace fossils. 109-130.

Davies AG (1950) The radiolarian of the Hawasina Series of Oman. Proceedings of the Geologists Association 11: 206-217.

Ellison RA, Woods MA, Pickett EA (2006) Geology of the Wadi Haqil 1:25 000 map sheet, 25-1, United Arab Emirates. Keyworth, Nottingham: British Geological Survey.

Ellison RA, Arkley SLB, Warrak M, Farrant AR (2006) Geology of the Al Ain 1:50 000 map sheet, 50-6, United Arab Emirates. Keyworth, Nottingham: British Geological Survey.

Ellison RA, Woods MA, Pickett EA, Arkley SLB (2006) Geology of the Al Rams 1:50 000 map sheet, 50-1, United Arab Emirates. Keyworth, Nottingham: British Geological Survey.

Farrant AR, Ellison RA, Arkley SLB (2006) Geology of the Ras Al Khaimah 1:100 000 map sheet, 100-1, United Arab Emirates. Keyworth, Nottingham: British Geological Survey. 
Forbes GA, Jansen HSM, Schreurs J (editors) (2010). Lexicon of Oman: Subsurface Stratigraphy: Reference Guide to the Stratigraphy of Oman's Hydrocarbon Basins. GeoArabia Special Publication 5 .

Fürsich FT, Taheri J, Wilmsen M. (2007) New occurrences of the trace fossil Paleodictyon in shallow marine environments: examples from the Triassic-Jurassic of Iran. Palaios 22: 408-416.

Garrison RE, Fischer AG (1969) Deep-water limestones and radiolarites of the Alpine Jurassic. In Friedman GM (ed) Depositional Environments in Carbonate Rocks. Special Publication- Society of Economic Paleontologists and Mineralogists 14: 20-56.

Glennie KW, Boeuf MGA, Hughes-Clark MW, Moody-Stewart M, Pilaar WHF, Reinhardt BM (1974) Geology of the Oman Mountains. Verhandelingen van het Koninklijk Nederlands geologisch mijnbouwkundig Genootschap, Transactions 31: pp 423.

Gill GA, Santantonio M, Lathuiliere B (2004) The depth of pelagic deposits in the Tethyan Jurassic and the use of corals: an example from the Apennines. Sedimentary Geology 166: 311-334.

Graham GM (1980a) Evolution of a passive margin and nappe emplacement in the Oman Mountains. In Panayiotou A (ed) Proceedings of the International Ophiolite Symposium, Cyprus 1979. 414-423.

Graham GM (1980b) Structure and sedimentology of the Hawasina window, Oman Mountains. Unpublished PhD thesis, Open University.

Hardenbol J, Thierry J, Farley MB, Jacquin T, De Graciansky PC, Vail PR (1998) Jurassic sequence chronostratigraphy. In De Graciansky PC, Hardenbol J, Jacquin T, Vail PR (eds) Mesozoic and Cenozoic Sequence Stratigraphy of European Basins. Special Publication-Society of Economic Paleontologists and Mineralogists 60: chart 6.

Hollmann R (1964) Subsolutions-Fragmente (Zur Biostratinomie der Ammonoidea im Malm des Monte Baldo/Norditalien). N. J. Geol. Pala"ontol. Abh. 119: 22-82.

Hudson RGS, Browne RV, Chatton M (1954a) The structure and stratigraphy of the Jebel Qamar area, Oman. Proceedings of the Geological Society of London 1513: 49-54.

Hudson RGS, McGugan A, Morton DM (1954b) The structure of the Jebel Hagab area, Trucial Oman. Quarterly Journal of the Geological Society of London 110: 121-152.

Immenhauser A, Schreurs G, Peters T, Matter A, Hauser M, Dumitrica P (1999) Stratigraphy, sedimentology and depositional environments of the Permian to Cretaceous Batain Group, easternOman. Eclogae Geologica Helvetica 91: 217-235.

Jenkyns HC (1986) Pelagic environments. In Reading HG (ed) Sedimentary Environments and Facies 2nd edition. Blackwell, Oxford. 343-398.

Jenkyns HC, Winterer EL (1982) Palaeoceanography of Mesozoic ribbon radiolarites. Earth Planet Science Letters 60: 351-375.

Kametaka M, Takebe M, Nagai H, Zhu S, Takayanagi Y (2005) Sedimentary environments of the Middle Permian phosphorite-chert complex from the northeastern Yangtze platform, China; the Gufeng Formation: a continental shelf radiolarian chert. Sedimentary Geology 174: 197-222. 
Kennedy WJ, Simmons MD (1991) Mid-Cretaceous ammonites and associated microfossils from the Central Oman Mountains. Newsletters on Stratigraphy 25: 127-154.

Lanphere MA (1981) K-Ar Ages of Metamorphic Rocks at the Base of the Samail Ophiolite, Oman. Journal of Geophysical Research 86: 2777-2782.

Leturmy P, Robin C (editors) (2010) Tectonic and Stratigraphic Evolution of Zagros and Makran during the Mesozoic-Cenozoic. Geological Society of London Special Publication 330. pp 360.

Lippard SJ, Rex DC (1982) K-Ar ages of alkaline igneous rocks in the northern Oman mountains, NE Arabia, and their relations to rifting, passive margin development and destruction of the Oman Tethys. Geological Magazine 119: 497-503.

Lippard SJ, Shelton AW, Gass IG (1986) The Ophiolite of Northern Oman. Geological Society, London, Memoir 11. Blackwell Scientific Publications, Oxford.

Lippard SJ, Smewing JD, Rothery DA, Browning P (1982) The geology of the Dibba zone, northern Oman mountains; a preliminary study. Journal of the Geological Society, London 139: 59-66.

Maceachern JA, Pemberton SG, Gingras MK, Bann K (2007) The ichnofacies Paradigm: A FiftyYear Retrospective. In Miller W (ed) Trace Fossils, concepts, problems, prospects. Elsevier. 52-77.

Masse J-P, Borgomano JRF, Al Maskiry S (1997) Stratigraphy and tectono-sedimentary evolution of late Aptian-Albian carbonate margin: the northeastern Jebel Akhdar (Sultanate of Oman). Sedimentary Geology 113: 269-280.

Masse J-P, Borgomano JRF, Al Maskiry S (1998). A platform-to-basin transition for lower Aptian carbonates (Shuaiba Formation) of the northeastern Jebel Akhdar (Sultanate of Oman). Sedimentary Geology 119: 297-309.

Matsuda T, Isozaki Y (1991) Well-documented travel history of Mesozoic bedded chert from remote ocean to subduction zone. Tectonics 10: 475-99.

Le Métour J, Béchennec RJ, Wyns R (1992) Geological Map of Musandam and Mudha, explanatory notes. Muscat: Ministry of Petroleum and Minerals, Sultanate of Oman.

Ogg JG, Ogg G, Gradstein FM (2008) The Concise Geologic Time Scale. Cambridge University Press.

Parsons B, Sclater JG (1977) An analysis of the variation of ocean floor bathymetry and heat flow with age. Journal of Geophysical Research 82: 803-827.

Philip J, Borgomano J, Al-Maskiry S (1995) Cenomanian-Early Turonian carbonate platform of Northern Oman: stratigraphy and palaeo-environments. Palaeogeography, Palaeoclimatology, Palaeoecology 119: 77-92.

Phillips ER, Ellison RA, Farrant AR, Goodenough KM, Arkley SLB, Styles MT (2006) Geology of the Dibba 1:50 000 map sheet, 50-2, United Arab Emirates. Keyworth, Nottingham: British Geological Survey.

Phillips ER, Ellison RA, Arkley SLB (2006) Geology of the Al Tawyen 1:25 000 map sheet, 25-2, United Arab Emirates. Keyworth, Nottingham: British Geological Survey. 
Phillips ER, Ellison RA, Waters, C (2011) The depositional and tectonic evolution of the southern margin of the Neotethys ocean. British Geological Survey Internal Report, IR/11/030. 181pp.

Ricateau R, Riché PH (1980) Geology of the Musandam Peninsula (Sultanate of Oman) and its surroundings. Journal of Petroleum Geology 3: 139-152.

Robertson AHF (1987) The transition from a passive margin to an Upper Cretaceous foreland basin related to ophiolite emplacement in the Oman Mountains. Geological Society of America Bulletin 99: 633-653.

Robertson AHF, Blome CD, Cooper DWJ, Kemp AES, Searle MP (1990a) Evolution of the Arabian continental margin in the Dibba Zone, Northern Oman Mountains. In Robertson AHF, Searle MP, Ries AC (eds) The Geology and Tectonics of the Oman Region. Geological Society, London, Special Publication 49: 251-284

Robertson AHF, Kemp AES, Rex DC, Blome CD (1990b) Sedimentary and structural evolution of a continental margin transform lineament: the Hatta Zone, Northern Oman Mountains. In Robertson AHF, Searle MP, Ries AC (eds) The Geology and Tectonics of the Oman Region. Geological Society, London, Special Publication 49: 285-305.

Robertson AHF, Searle MP (1990) The northern Oman Tethyan continental margin: stratigraphy, structure, concepts and controversies. In Robertson AHF, Searle MP, Ries AC (eds) The Geology and Tectonics of the Oman Region. Geological Society, London, Special Publication 49: 3-25

Rousseau, M, Dromart G, Garcia J-P, Atrops F, Guillocheau F (2005) Jurassic evolution of the Arabian carbonate edge in the central Oman Mountains. Journal of the Geological Society, London 162: $349-362$.

Santantonio M (1994) Pelagic carbonate platforms in the geologic record: their classification, and sedimentary and paleotectonic evolution. AAPG Bulletin 78: 122-141.

Searle MP (1980) The metamorphic sheet and underlying volcanic rocks beneath the Oman ophiolite in the northern Oman mountains of Arabia. Unpublished PhD Thesis, Open University.

Searle MP (1985) Sequence of thrusting and origin of culminations in the northern and central Oman Mountains. Journal of Structural Geology 7: 129-143.

Searle MP (1988a) Thrust tectonics of the Dibba zone and the structural evolution of the Arabian continental margin along the Musandam mountains (Oman and United Arab Emirates). Journal of the Geological Society, London 145: 43-53.

Searle MP (1988b) Structure of the Musandam culmination (Sultanate of Oman and United Arab Emirates) and the Straits of Hormuz syntaxis. Journal of the Geological Society, London 145: 831845.

Searle MP, Cooper DWJ (1986) Structure of the Hawasina Window culmination, central Oman Mountains. Transactions of the Royal Society of Edinburgh 77: 143-156.

Searle MP, James NP, Calon TJ, Smewing JD (1983) Sedimentological and structural evolution of the Arabian continental margin in the Musandam Mountains and Dibba zone, United Arab Emirates. Geological Society of American Bulletin 94: 1381-1400. 
Searle MP, Lippard SJ, Smewing JD, Rex DC (1980) Volcanic rocks beneath the Semail Ophiolite nappe in the northern Oman mountains and their significance in the Mesozoic evolution of Tethys. Journal of the Geological Society, London 137: 589-604.

Searle MP, Malpas J (1980) Structure and metamorphism of rocks beneath the Semail ophiolite of Oman and their significance in ophiolite obduction. Transactions of the Royal Society of Edinburgh: Earth Sciences 71:247-262.

Seilacher A (1967) Bathymetry of trace fossils. Marine Geology 5: 413-428.

Seilacher A (1978) Use of trace fossil assemblages for recognizing depositional environments. In Basan PB (ed) Trace Fossil Concepts. Society of Economic Paleontologists and Mineralogists, Tulsa, OK, Short Course 5. 167-181.

Sharland PR, Archer R, Casey DM, Davies RB, Hall SH, Heward AP, Horbury AD, Simmons MD (2001) Arabian Plate Sequence Stratigraphy. GeoArabia Special Publication 2. pp 372.

Simmons MD, Hart MB (1987) The biostratigraphy and microfacies of the early to Mid Cretaceous carbonates of Wadi Mi'aidin, Central Oman Mountains. In Hart MB (editor) Micropalaeontology of Carbonate Environments. Chichester: Ellis Horwood. 176-207.

Stow DVA, Reading HG, Collinson JD (1996) Deep seas. In Reading HG (ed) Sedimentary Environments: Processes, Facies and Stratigraphy. Blackwell Science, Oxford. 395-453

Styles MT, Ellison RA, Phillips ER. Arkley S, Schofield DI, Thomas RJ, Goodenough KM, Farrant AR, McKervey JA, Crowley QG, Pharaoh TC (2006) The geology and geophysics of the United Arab Emirates: Volume 2, Geology. Ministry of Energy, United Arab Emirates, Abu Dhabi. pp 351.

Takebe M, Kametaka M, Takayanagi Y, Mimura K, Sugitani K, Yamamoto K (2007) Origin and deposition of organic matter in continental chert of the Middle Permian Gufeng Formation in the northeastern Yangtze platform. Sedimentary Geology 201: 141-148.

Toland C, Peebles RG, et al. (1993) Upper Jurassic and basal Cretaceous outcrop sequence stratigraphy of Wadi Hagil, Ras Al Khaimah. Society of Petroleum Engineers. 25581: 533-543.

van Buchem FSP, Pittet B, Hillgärtner H, Grötsch J, Al Mansouri AI, Billing IM, Droste HHJ, Oterdoom WH (2002a) High-resolution Sequence Stratigraphic Architecture of Barremian/Aptian Carbonate Systems in Northern Oman and the United Arab Emirates (Kharaib and Shu'aiba Formations). GeoArabia 7: 461-498.

van Buchem FSP, Razin P, Homewood PW, Oterdoom WH, Philip J (2002b) Stratigraphic Organization of Carbonate Ramps and Organic-Rich Intrashelf Basins: Natih Formation (Middle Cretaceous) of Northern Oman. AAPG Bulletin 86: 21-53.

van Buchem FSP, Al-Hussein MI, Maurer F, Droste, HJ (editors) (2009) Barremian - Aptian stratigraphy and hydrocarbon habitat of the eastern Arabian Plate. GeoArabia Special Publication 4. 2 vols. pp 614.

van Buchem FSP, Gerdes KD, Estaban M (editors) (2010) Mesozoic and Cenozoic Carbonate Systems of the Mediterranean and the Middle East: Stratigraphic and Diagenetic Reference Models. 
Watts KF (1990) Mesozoic carbonate slope facies marking the Arabian platform margin in Oman: depositional history, morphology and paleogeography. In Robertson AHF, Searle MP, Ries AC (eds) The Geology and Tectonics of the Oman Region. Geological Society, London, Special Publication 49: 139-159.

Watts KF, Garrison RE (1986) Sumeini Group, Oman — evolution of a Mesozoic carbonate slope on a south Tethyan continental margin. Sedimentary Geology 48: 107-168.

Watts KF, Blome CD (1990) Evolution of the Arabian carbonate platform margin slope and its response to orogenic closing of a Cretaceous ocean basin, Oman. In Tucker ME, Wilson JL, Crevello PD, Sarg JR, Read JF (eds) Carbonate platforms: facies, sequences and evolution. International Association of Sedimentologists Special Publication 9: 291-323

Wilson HH (2000) The age if the Hawasina and other problems of Oman Mountain Geology. Journal of Petroleum Geology 23: 345-362.

Winterer EL, Bosellini A (1981) Subsidence and sedimentation on Jurassic passive continental margin, southern Alps, Italy. AAPG Bulletin 65: 394-421.

Zeigler, MA (2001) Late Permian to Holocene paleofacies evolution of the Arabian Plate and its hydrocarbon occurrences. GeoArabia 6: 445-504.

\section{Figures}

Fig. 1 Simplified geological map of the United Arab Emirates and northern Oman showing the main localities visited during the study

Fig. 2 Correlation of the main lithostratigraphical units present within the UAE (Styles et al. 2006) and the Jebal Sumeini, Qumayrah, Jebal Akhdar, Adam areas of Oman examined during the present study. The general succession recognised elsewhere across the Arabian Plate is also included. The ages of the chronostratigraphical units are derived from Ogg et al. (2008) and the sea-level curves are sourced from Hardenbol et al. (1998)

Fig. 3 Lithological log of the succession present in the Wadi Mi'aidin and Birkat al Mawz section

Fig. 4 (a) Basal part of Unit B, Kharaib Formation, showing the presence of stylolitic surfaces, with one such prominent surface overlain by micrite and underlain by fusilinid wackestone, with some red weathering below the stylolite; (b) Basal part of the Nahr Umr Formation showing a hard, upwardfining Orbitolina limestone, overlain by soft, thin-bedded Orbitolina packstones, upward-fining to red- to yellow-brown mudstone; and (c) View to the east of the upper part of the Natih Formation, overlain unconformably by the Muti Formation. Note the presence of south-verging folds within the Muti Formation

Fig. 5 Lithological log of the succession at the Mayhah Formation at its type locality at Jebal Sumeini, northern Oman

Fig. 6 (a) Thinly planar bedded micrites with subordinate lenticular calcirudites. Note the unusual onlapping relationship of the micrite beds upon the lowermost calcirudite lens, which appears to have formed a positive topographical feature at the time of deposition, Jebal Sumeini, northern Oman [UTM 0386329 2742554]; (b) View of the upper part of the Mayhah Formation type locality from 
north of Jebel Sumeini, northern Oman [UTM 0386352 2743022] to [UTM 0386392 2743215]; and (c) On-lap relationship between the thinly bedded limestones of the Mayhah Formation and underlying boulder-grade calcirudites of the Ausaq Conglomerate Formation, northern side of the Dibba Zone, UAE. Bedding within the Mayhah Formation has been offset by a number of steeply south-easterly dipping extensional (normal) faults. Minor drag folding is also apparent associated with the larger faults

Fig. 7 (a) Thinly bedded calcarenites and calcilutites of the Guwayza Formation deformed by westerly verging angular folds, Hamrat Duru mountains, northern Oman [UTM 0514148 2509606]; (b) Welldeveloped soft-sediment deformation structures (convolute lamination) within the thinly bedded limestones of the Guwayza Formation, Hamrat Duru mountains, northern Oman [UTM 0514148 2509606]; (c) Coarsening and thickening upward cycle of sedimentation developed within the pale calcareous mudstones, bleached siliceous mudstones and turbiditic calcarenites of the Wahrah Formation. The limestone and calcareous mudstone sequence is overlain by a unit of poorly exposed, thinly bedded siliceous mudstones and cherts, Jebal Wahrah area, northern Oman [UTM 0471237 2567035]; (d) Massive, clast-supported calcirudite from the Nayid Formation comprising tabular, pebble sized clasts of calcarenite and calcirudite in a fine-grained dolomitised matrix Jebal Sumeini area, northern Oman [UTM 0392567 2732072]; and (e) Sole structures developed on the base of a turbiditic limestone bed (loose block), Nayid Formation, Jebal Sumeini area, northern Oman [UTM 039171 2731779]

Fig. 8 (a) Measured section through part of the Wahrah Formation, Jebal Wahrah area, northern Oman [UTM 0472084 2562548]; and (b) Measured section through part of the Sid'r Chert Formation, northern part of the Dibba Zone, UAE [UTM 0401218 2824012]

Fig. 9 (a) Large channel filled with thickly bedded calcirudites and coarse-grained calcarenites cutting down wards into the thinly bedded limestones which characterise the Nayid Formation, Hamrat Duru mountains, northern Oman [UTM 0510461 2511244]; (b) Thinly and rhythmically bedded, variably silicified calcarenites and calcilutites of the Nayid Formation, Hamrat Duru mountains, northern Oman [UTM 05104612511244$]$; and (c) Paleodictyon net-like burrows preserved on a bedding surface (loose block), Nayid Formation, Hamrat Duru mountains, northern Oman [UTM 0499020 2515132]

Fig. 10 Measured sections though parts of the Dhera Limestone Formation exposed within the Dibba Zone (a to c) of the UAE, [UTM 0416770 2826409], [UTM 0400588 2820894] and [UTM 0406477 2817940] respectively, and Jebal Dhera area (d) of northern Oman [UTM 0390330 2703457]

Fig. 11 (a) View of Jebal Dhera (northern Oman) showing the lithological variation within the Dhera Limestone Formation [UTM 0398988 2700876]; (b) Bed of coarse-grained calcirudite with a weakly developed lamination near the top, Dhera Limestone Formation, Jebal Dhera, area northern Oman [UTM 0397738 2700466]; (c) Erosive base to a coarse-grained, weakly cross-laminated Ta/b horizon and parallel-laminated Tc/d horizons in thinly bedded turbiditic limestones of the Dhera Limestone Formation, Jebal Sumeini area, northern Oman [UTM 0397061 2726460]; (d) Well-preserved meandering feeding traces/burrows on the bedding surfaces of turbiditic calcarenites, Dhera Limestone Formation, Jebal Sumeini area, northern Oman [UTM 0397061 2726460]; and (e) Overlapping burrows filled by coarser grained calcareous sand, Dhera Limestone Formation, Jebal Dhera area, northern Oman [UTM 0398230 2700589] 
Fig. 12 (a) The base of a grainstone bed shows platy chert, inferred to be secondary silicified limestone, with tool-mark like structures, Muti Formation, Wadi Mi'aidin, northern Oman; (b) View looking eastward of the upper part of the Muti Formation showing the transition from lower grainstones into the overlying thick-bedded packstones and wackestones and uppermost grainstones associated with two conglomerate beds, Wadi Mi'aidin, northern Oman; (c) Large angular block of dolostone floating within a matrix of upward-fining rudite, resting with a sharp base on a grey, thickbedded grainstone, Muti Formation, Wadi Mi'aidin, northern Oman; (d) Thinly interbedded fine grainstones with abundant platy chert overlain by coarse-grained lenticular bedded grainstones, boundary about $35 \mathrm{~m}$ above base of succession, Muti Formation, Wadi Mi'aidin, northern Oman; and (e) Detail of porcellanous lime mudstone, very thinly planar bedded, with thin grainstone bed, crosslaminated with starved rippled top and loaded base, from top of section, Muti Formation, Wadi Mi'aidin, northern Oman

Fig. 13 Measured section through part of the Qumayrah Limestone and Mudstone Member succession exposed at Qumayrah, northern Oman [UTM 0417581 2647473]

Fig. 14 (a) Detail if the very thinly planar bedded red silicified mudstones with a prominent pale grey swaley bedded grainstone bed, Qumayrah Limestone and Mudstone Member, Qumayrah, northern Oman [UTM 0417581 2647473]; (b) A single ooidal limestone bed showing the transition from crosslaminated at the base to planar laminated in the upper part, with starved current ripples on the top, Qumayrah Limestone and Mudstone Member, Qumayrah, northern Oman [UTM 0417910 2647498]; and (c) Green, clast-supported diamicton with a muddy matrix resting with a sharp base upon green mudstone, Qumayrah Limestone and Mudstone Member, Qumayrah, northern Oman [UTM 0418303 2647443]

Fig. 15 A schematic 3D block diagram showing the relationships between the inner ramp limestones of the Musandam Group, mid-ramp to outer-ramp deposits of the Mayhah Formation (Member A) and the deeper water sedimentary rocks of the Shamal Chert Formation during the Bajocian

Fig. 16 A schematic 3D block diagram showing the relationships between the mid-ramp limestones of the Thamama Group, outer-ramp deposits of the Mayhah Formation (Member B) and the deeper water sedimentary rocks of the Sid'r Chert Formation during the Berriasian

Fig. 17 (a) Palaeoreconstruction of the north-eastern Arabian continental margin during the Aptian to Albian (after Zeigler et al. 1991); and (b) Palaeoreconstruction of the southern margin of Neotethys in the UAE and northern Oman (this study)

Fig. 18 A schematic 3D block diagram showing the relationships between the shelf limestones of the Wasia Group, shelf slope deposits of the Mayhah Formation and the deeper water sedimentary rocks of the Hamrat Duru Group during the Albian

Fig. 19 A schematic 3D block diagram showing the depositional environment of the Mayhah Formation and the relationship between the Ausaq Conglomerate and major extensional faulting along the carbonate platform margin during the Turonian

Fig. 20 (a) Palaeoreconstruction of the north-eastern Arabian continental margin during the Cenomanian to late Turonian (after Zeigler 1991). (b) Palaeoreconstruction of the southern margin of Neotethys in the UAE and northern Oman (this study) from the late Turonian to Coniacian 
Fig. 21 A schematic 3D block diagram showing the relationships between the Muti Formation and Qumayrah and Riyamah members of the Aruma Group during the Coniacian

\section{Tables}

Table 1. Summary of the main features of the carbonate platform of the Hajar Supergroup at outcrop

Table 2. Summary of the main features of the carbonate platform margin sedimentary sequence

Table 3. Summary of the main features of the outer platform margin to basin sedimentary sequence

Table 4. Summary of the main features of the basinal sedimentary sequence and volcanic rocks

Table 5. Summary of the main features of the syn- and post-obduction foreland basin sedimentary sequence 


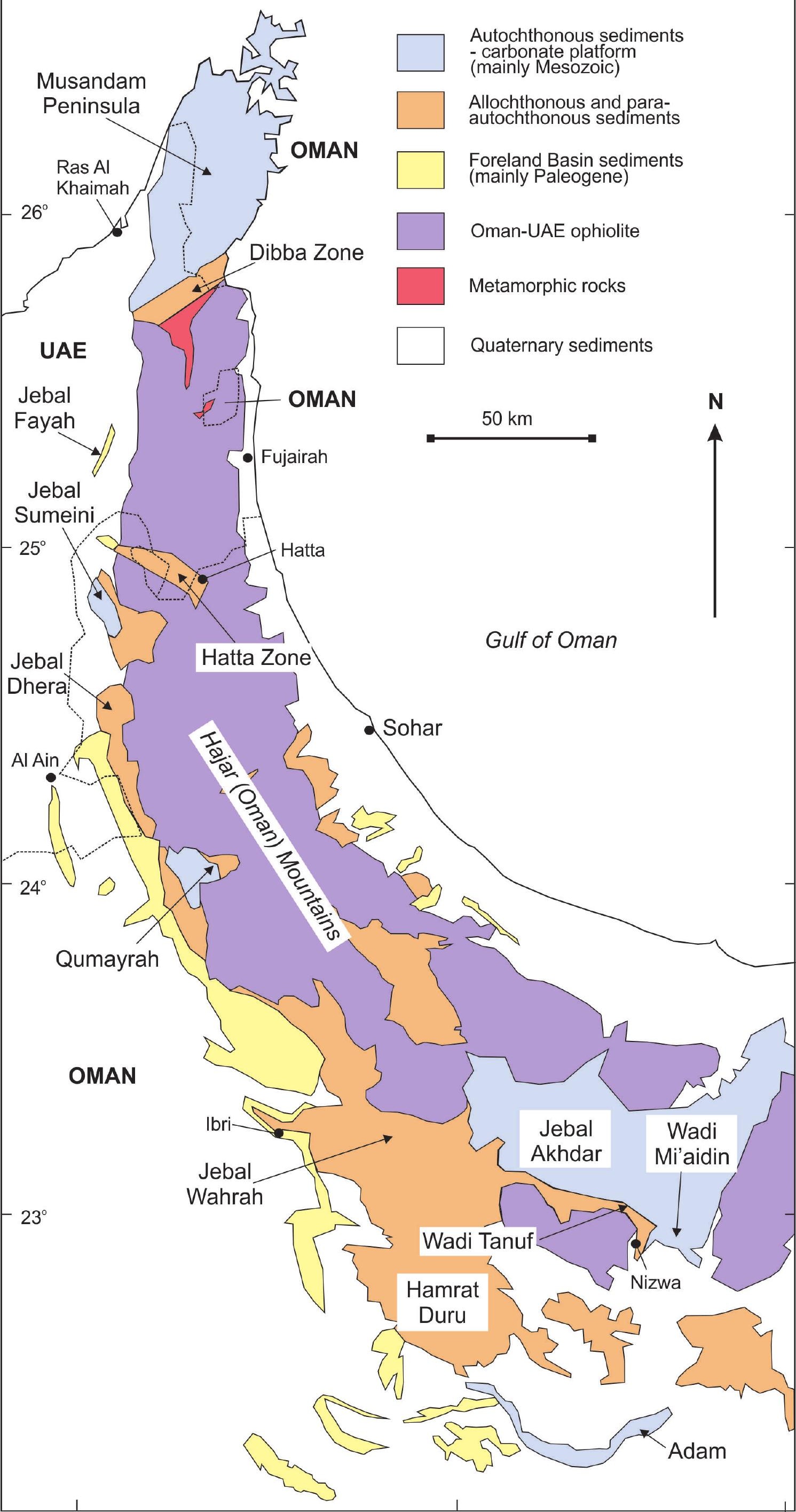


60,000000

00000000

000000000

0000000

0

0000000000

60000000

- o o 0000000

0.00000000

00000000

, 000000000

0080000

400

0.000000

0

00 Conglomerate/calcirudite

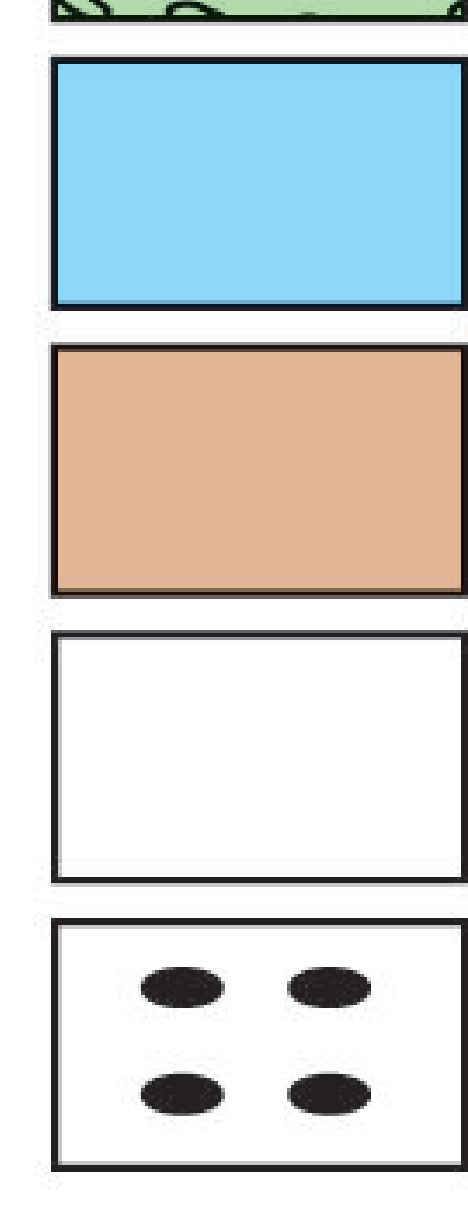

Limestone

olomitic limestone

Mudstone

Silicified mudstone/chert

$\pi$ Cross lamination

$\otimes \quad$ Secondary chert

jø Burrows

$\sim \quad$ Wave ripples

Faulted contact

Corals

= Planar bedded/laminated

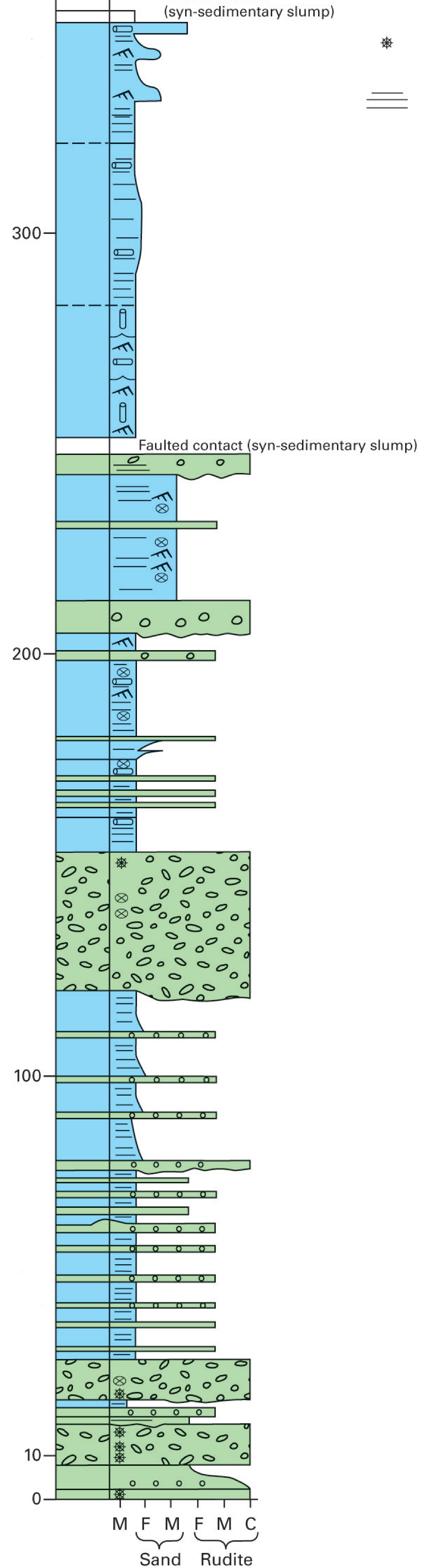



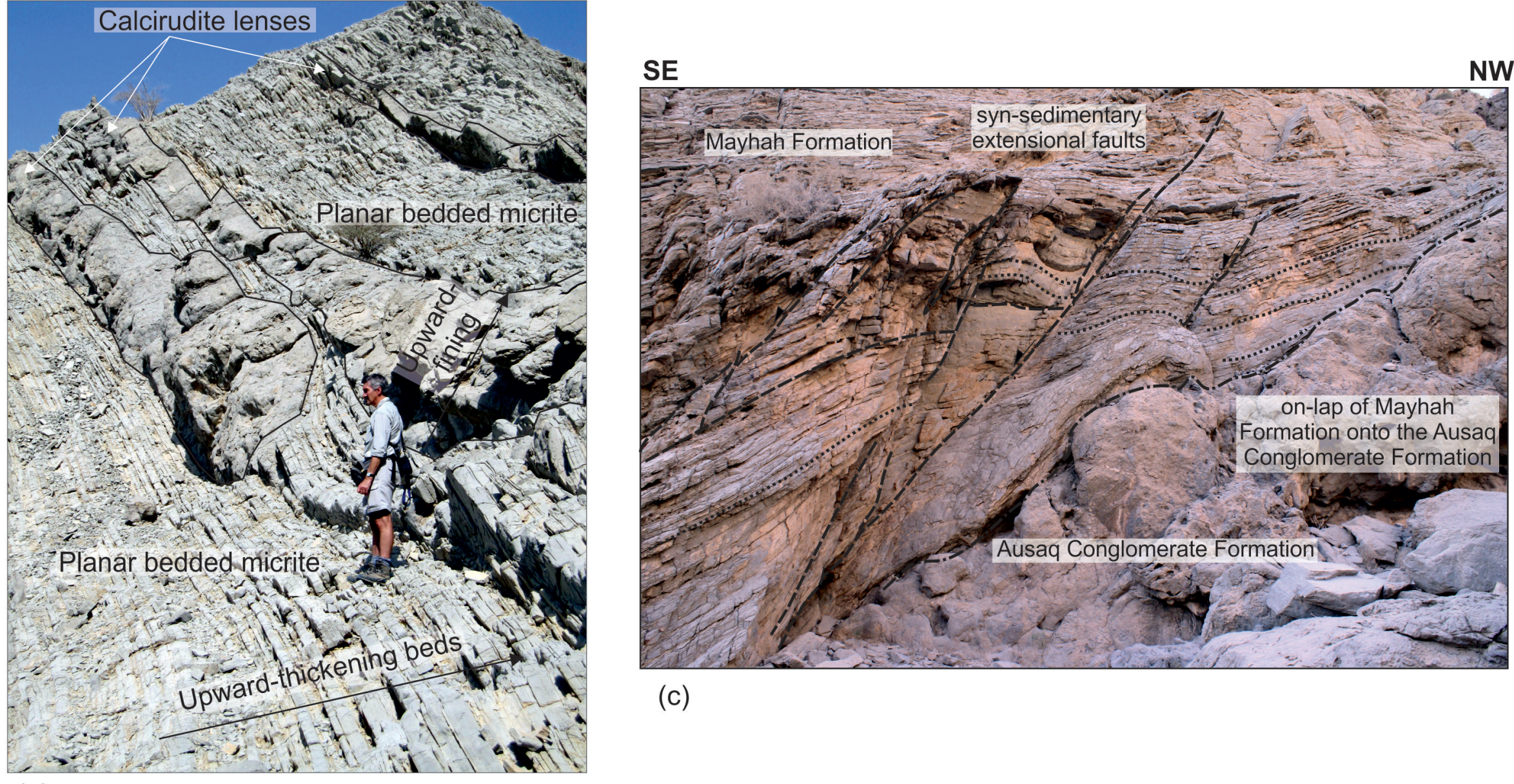

(c)

(a)

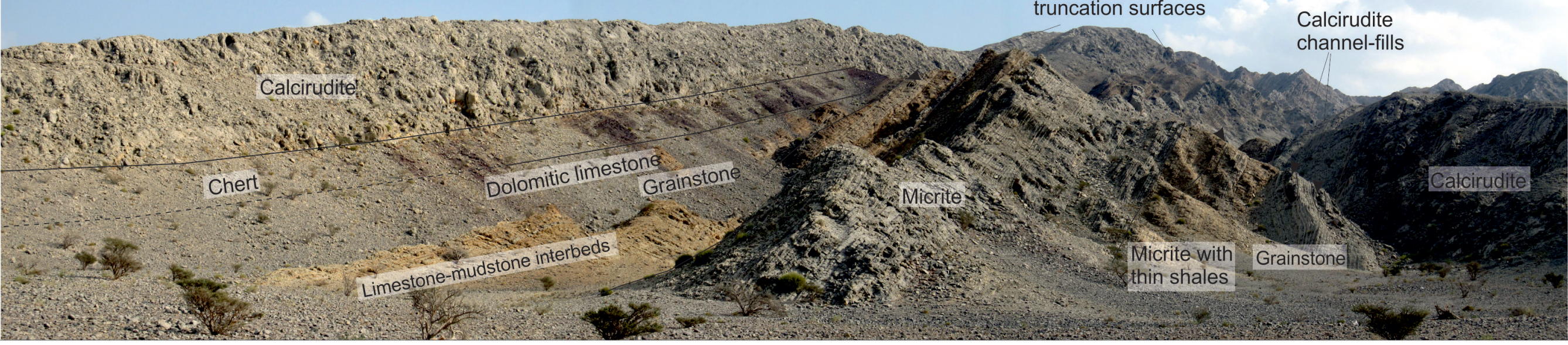

(b)

$$
100 \mathrm{~m}
$$




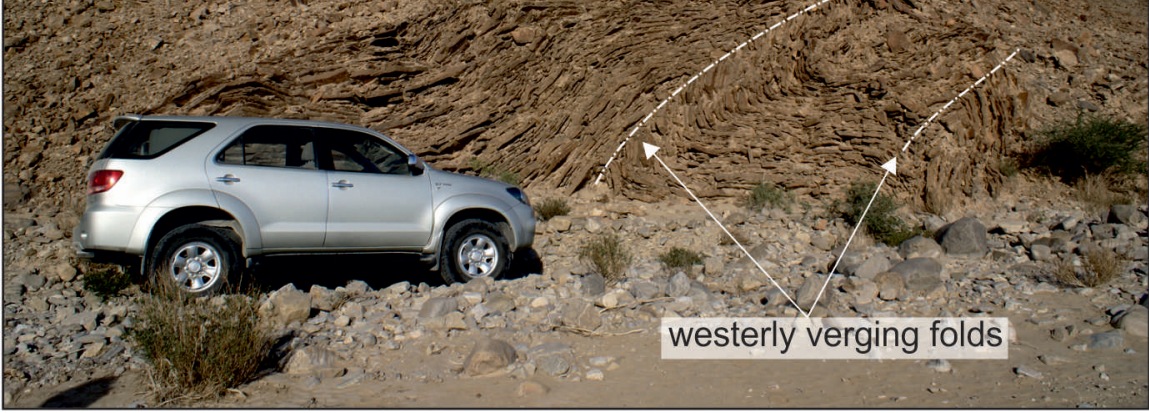

(a)

coarsening and thickening upwards cycle

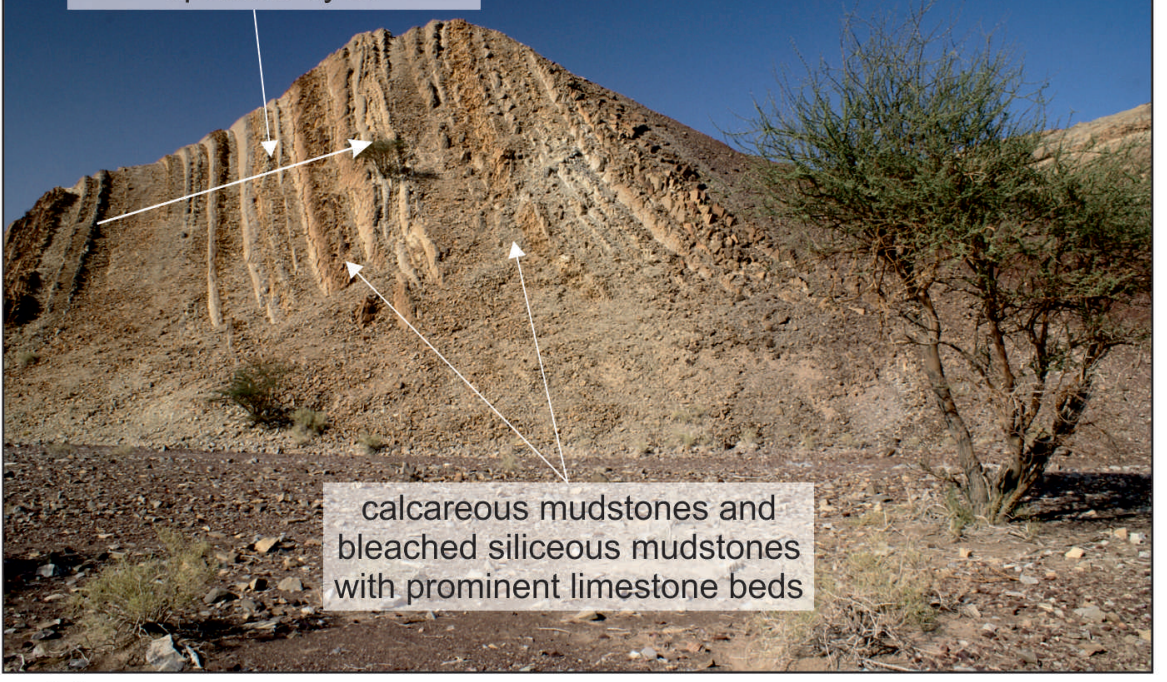

(c)

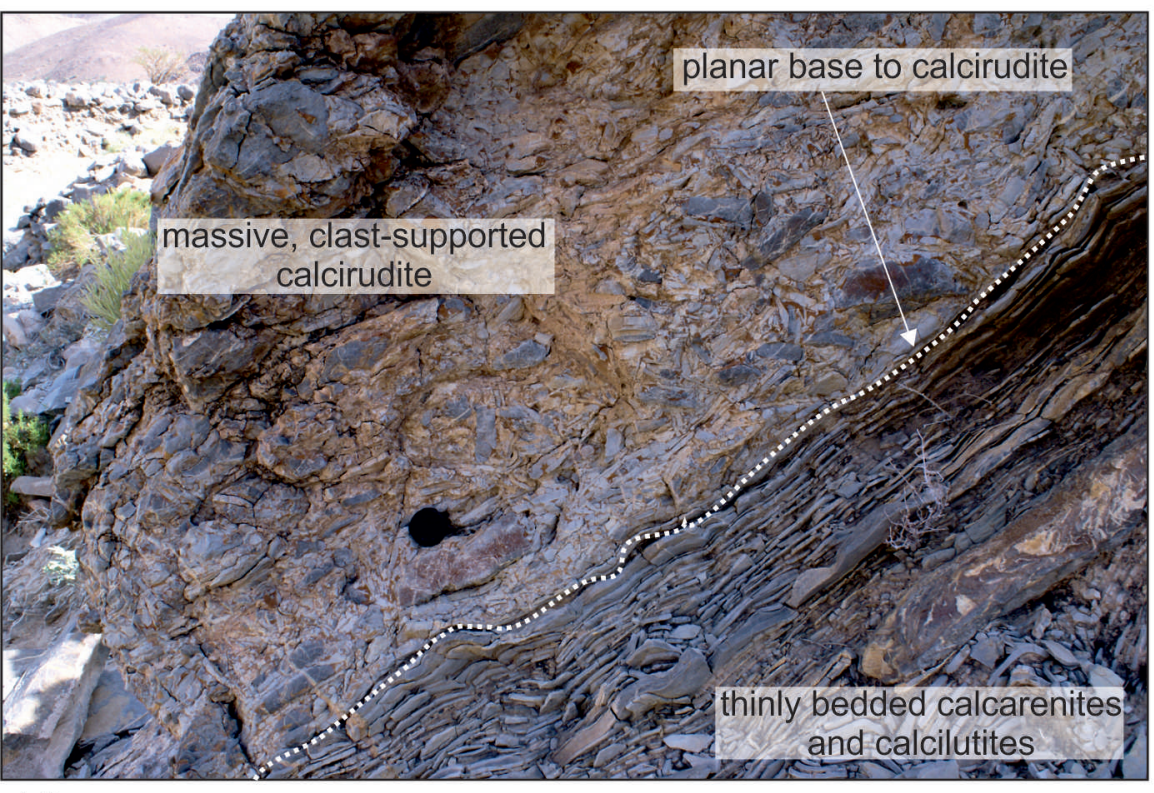

(d)

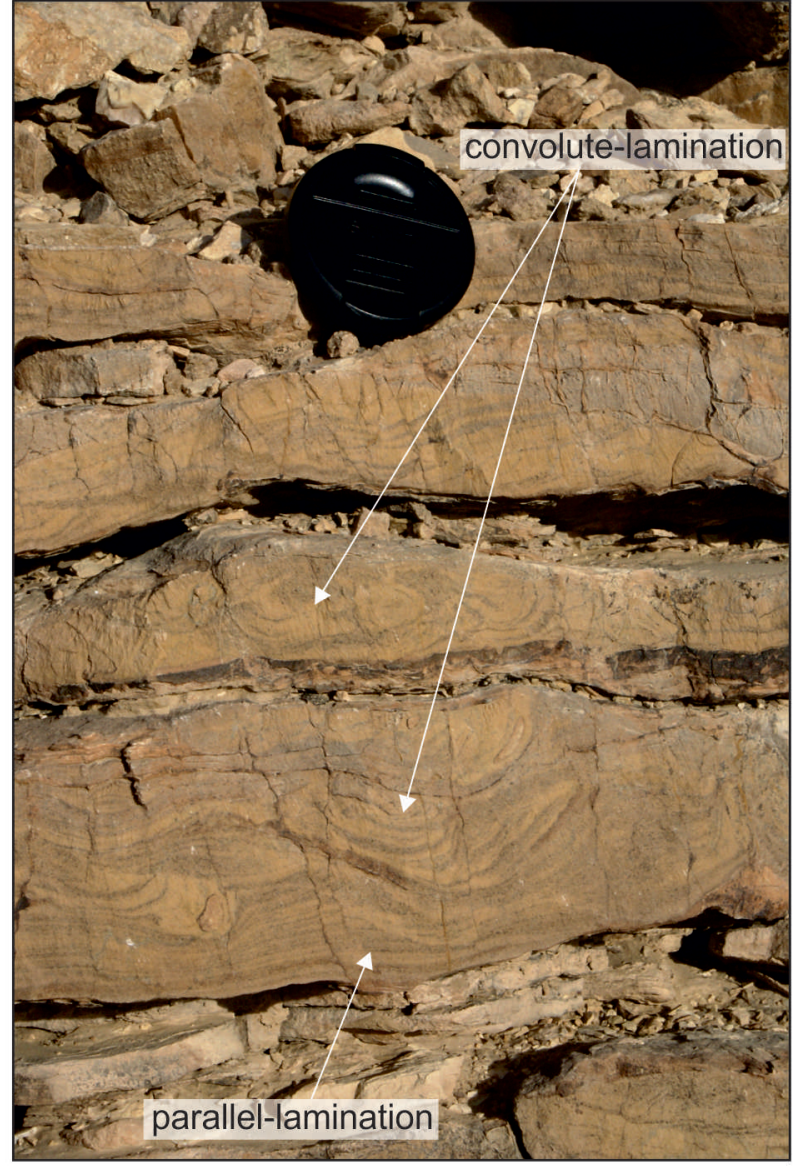

(b)

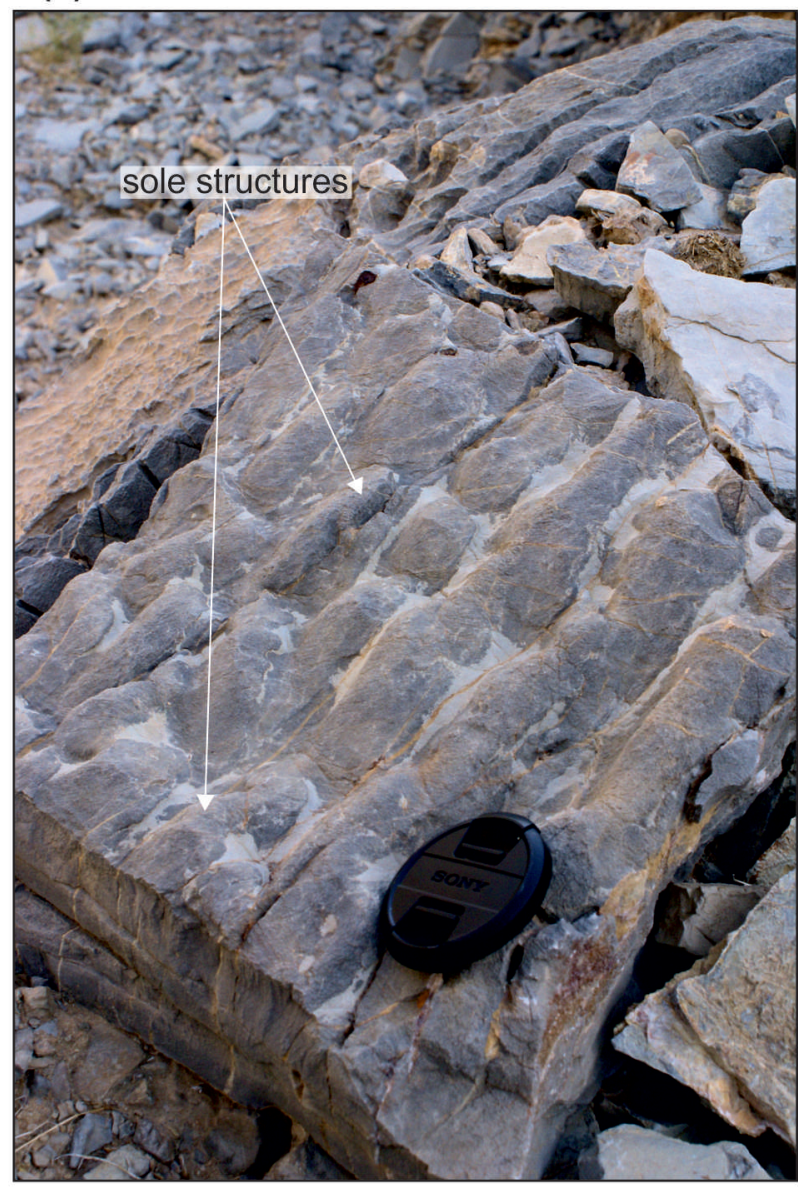

(e) 
metres
70 


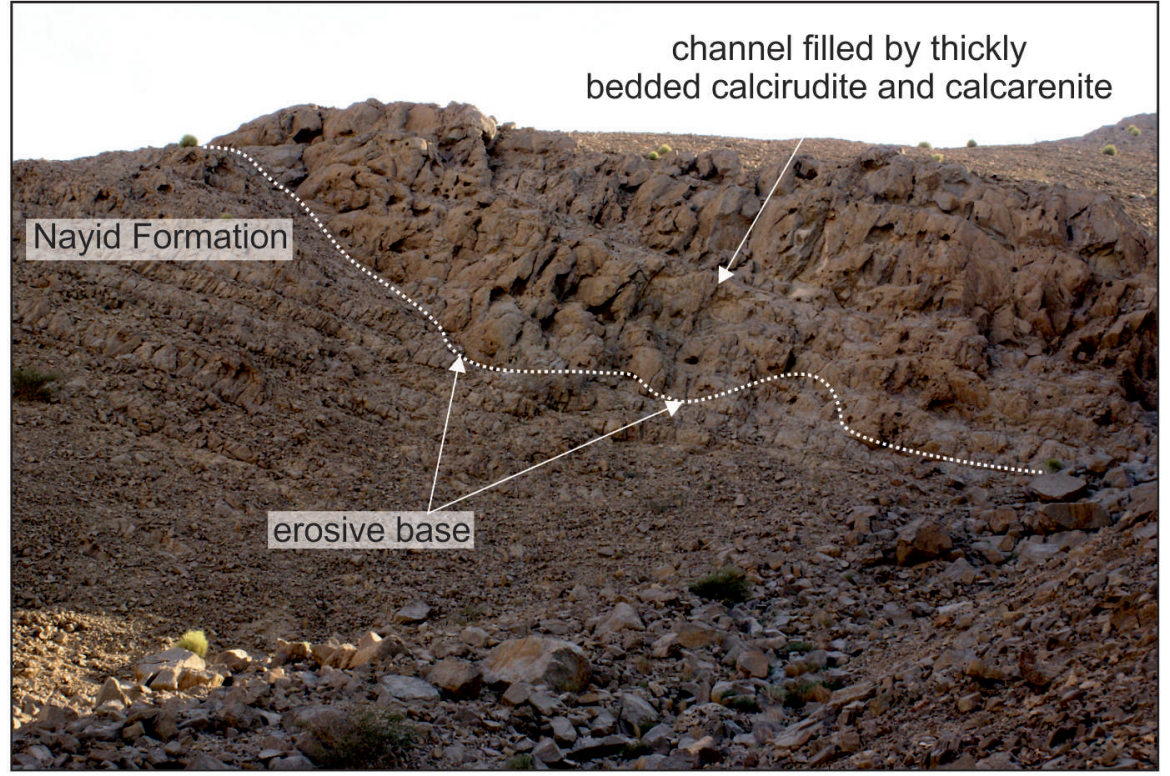

(a)

thinly bedded calcarenites and calcilutites

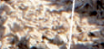

$3 x^{2}=y^{2}$

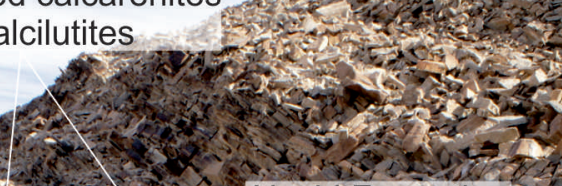

Nayid Formation

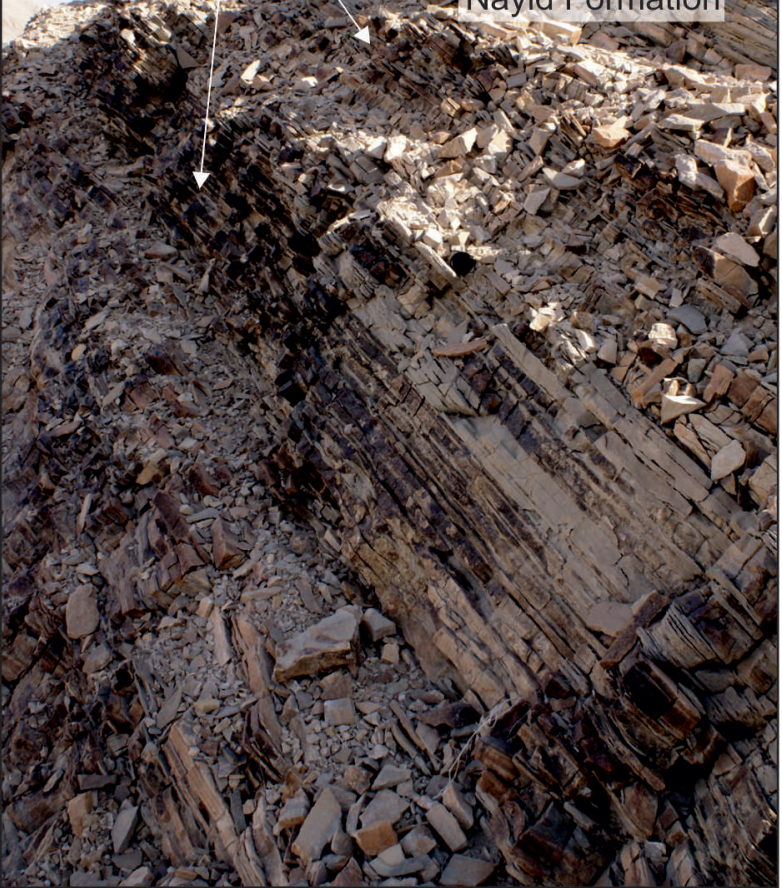

(b)

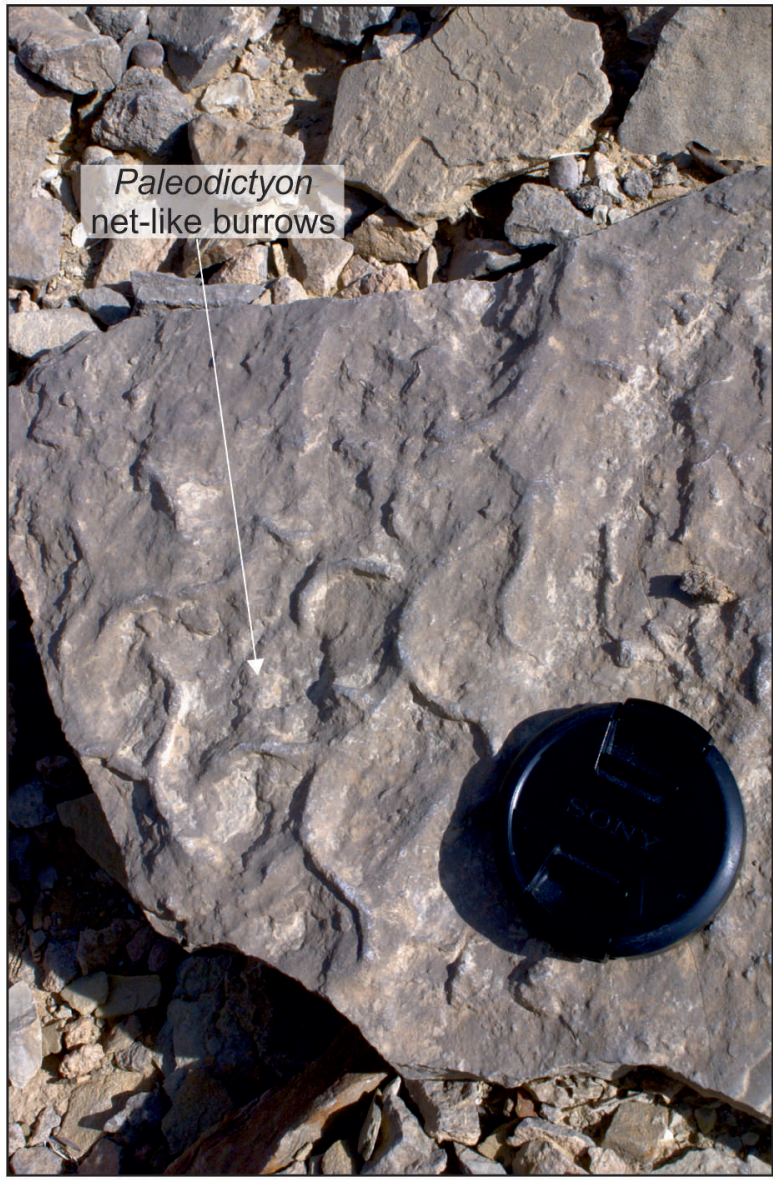

(c) 


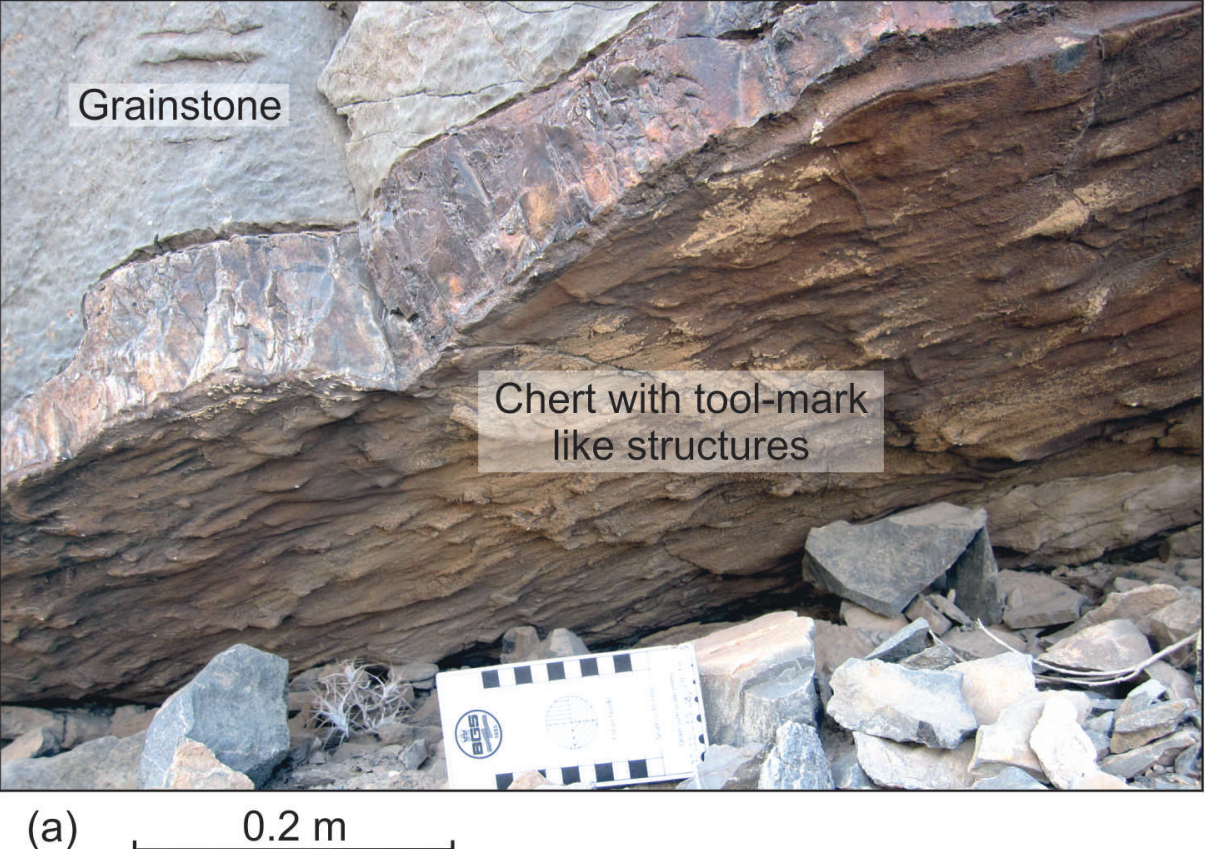

(a)

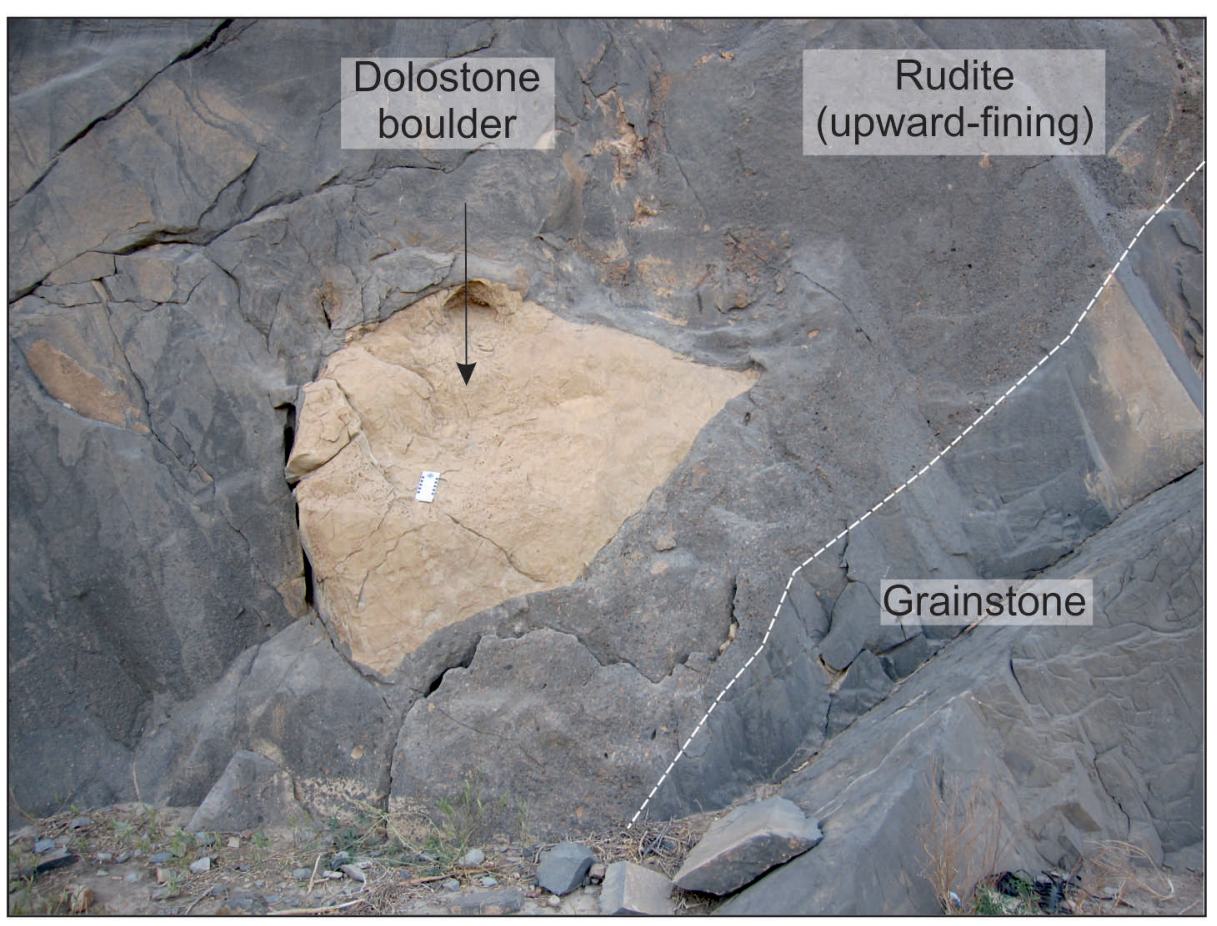

(c) $1 \mathrm{~m}$
Upper conglomerate

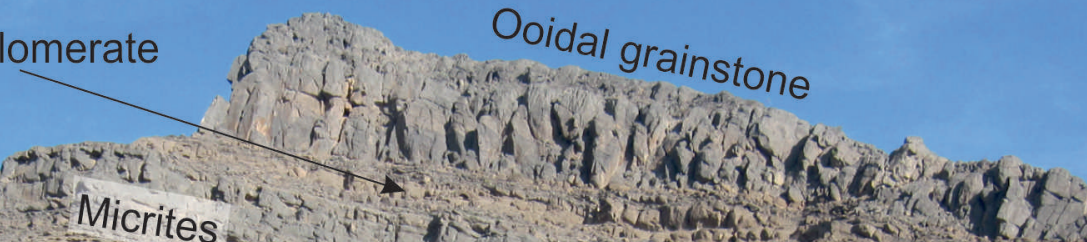

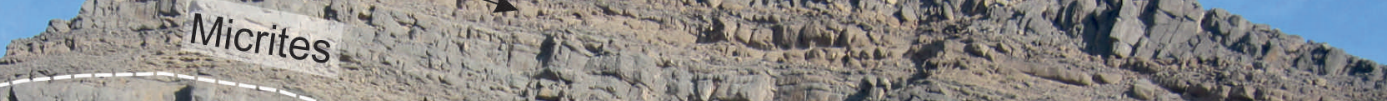

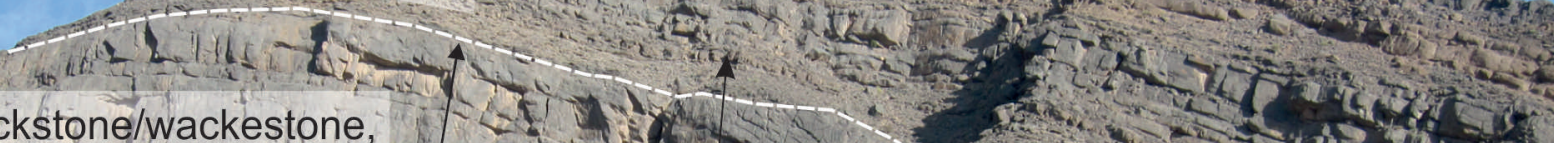

Packstone/wackestone, unward-thickening beds

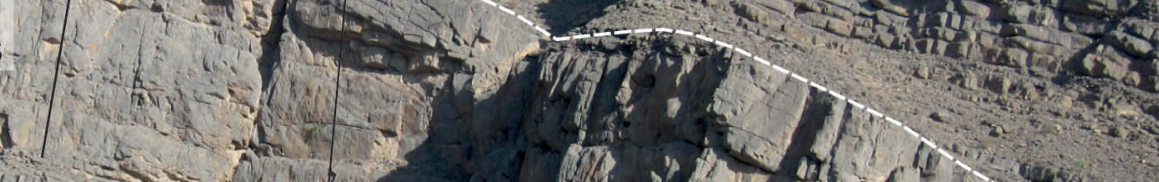

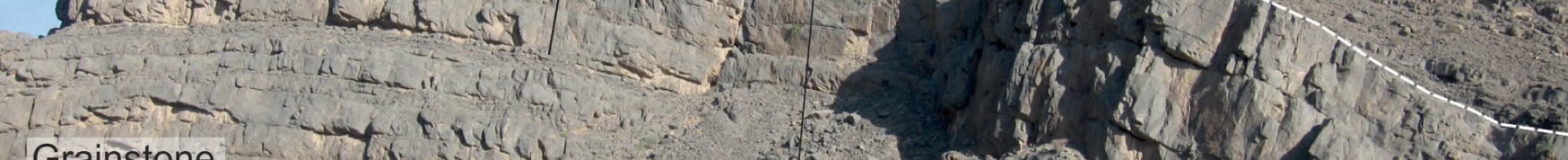
Grainstone Lower conglomerate

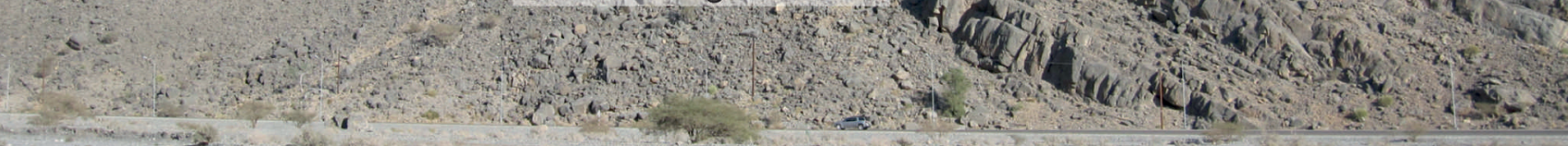

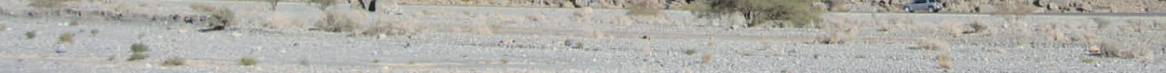

(b) $30 \mathrm{~m}$

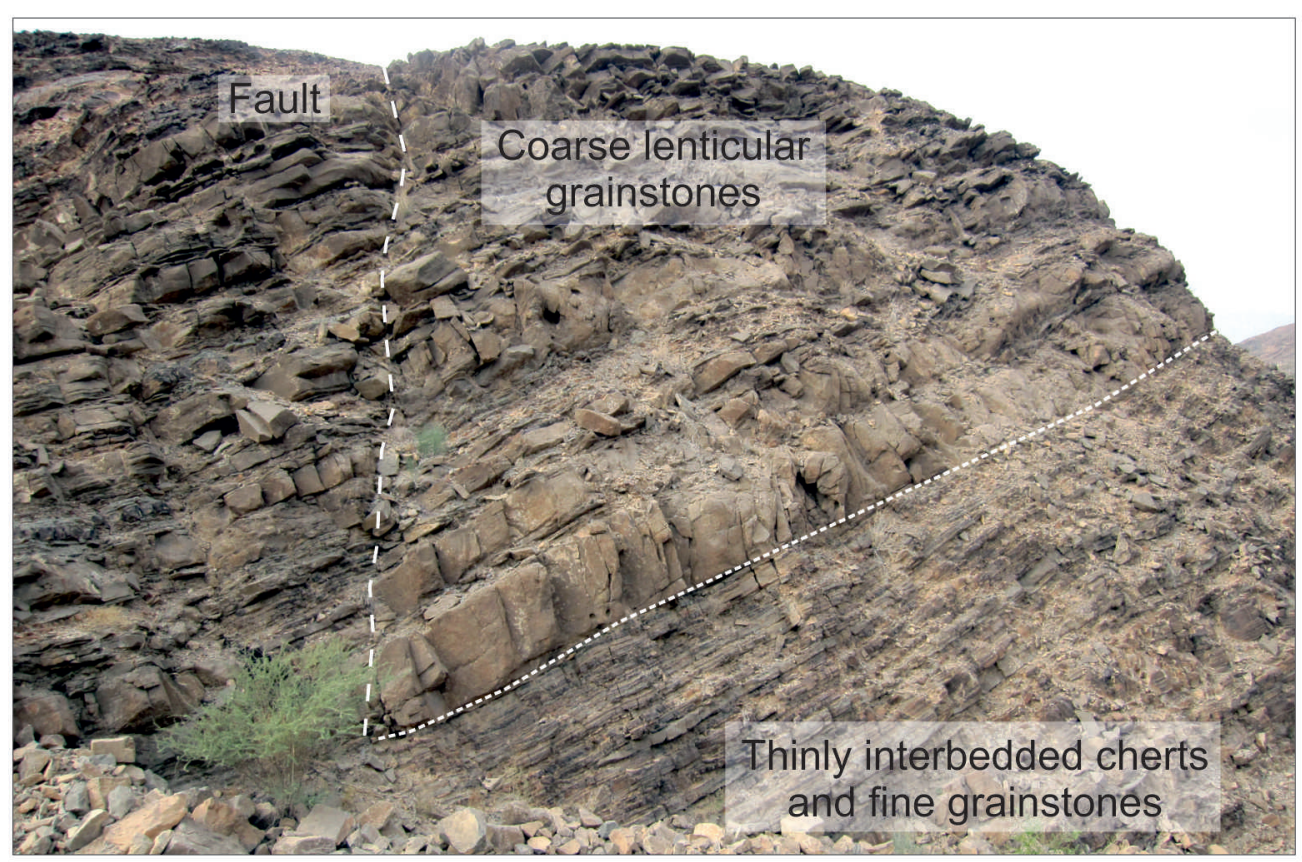

(d)

Thin grainstone bed, cross-laminated with loaded base

Very thinly planar bedded micrite

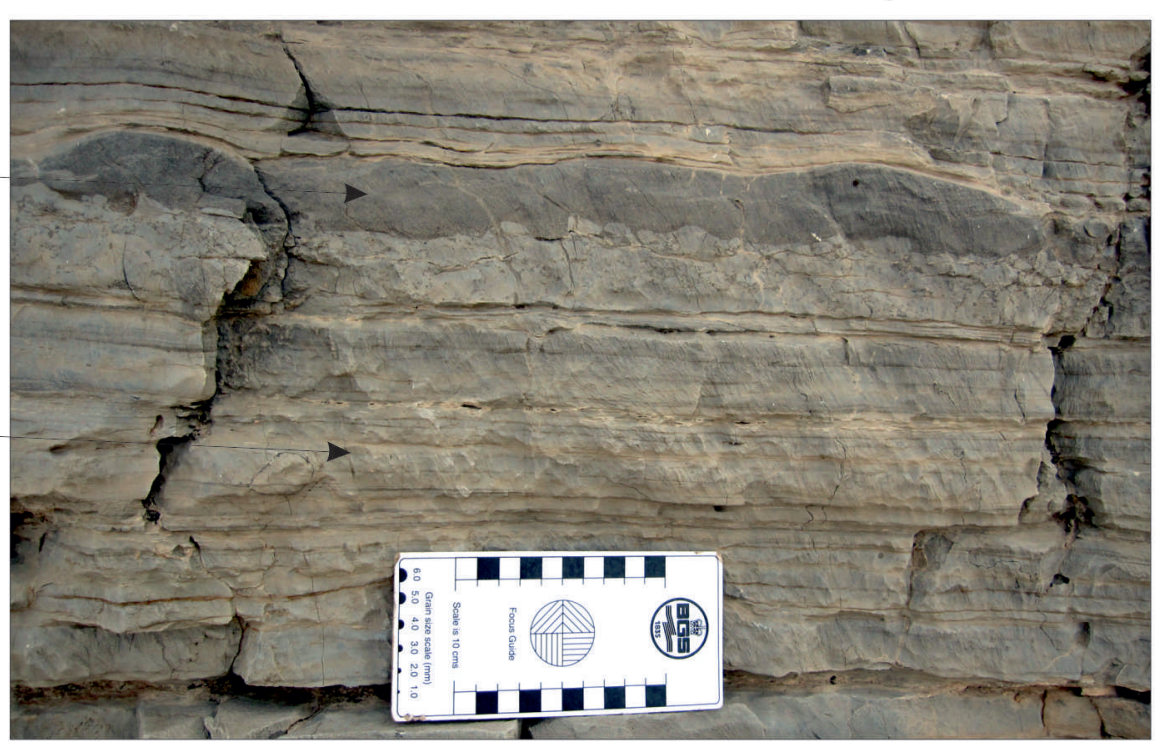

(e) 


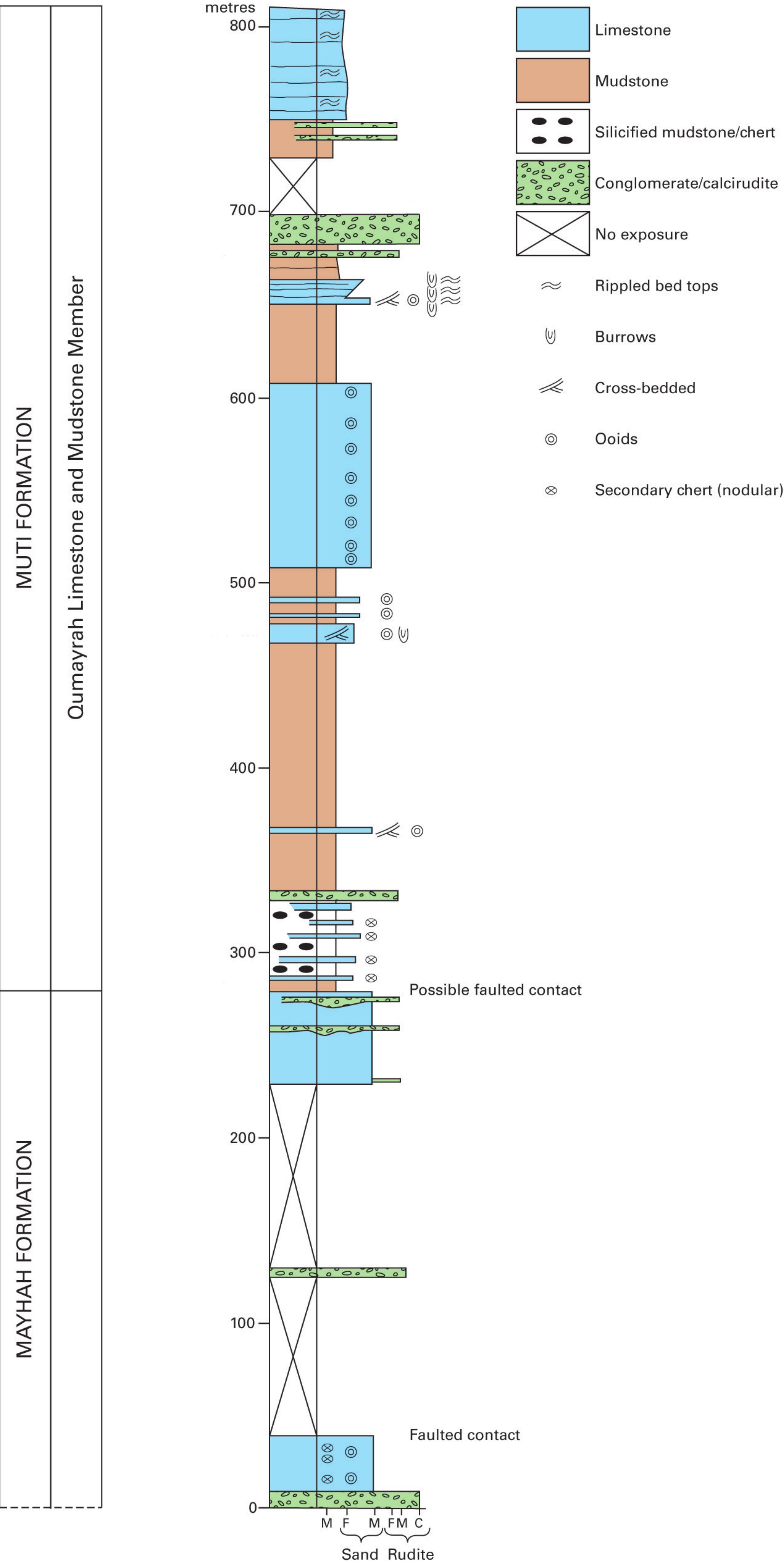




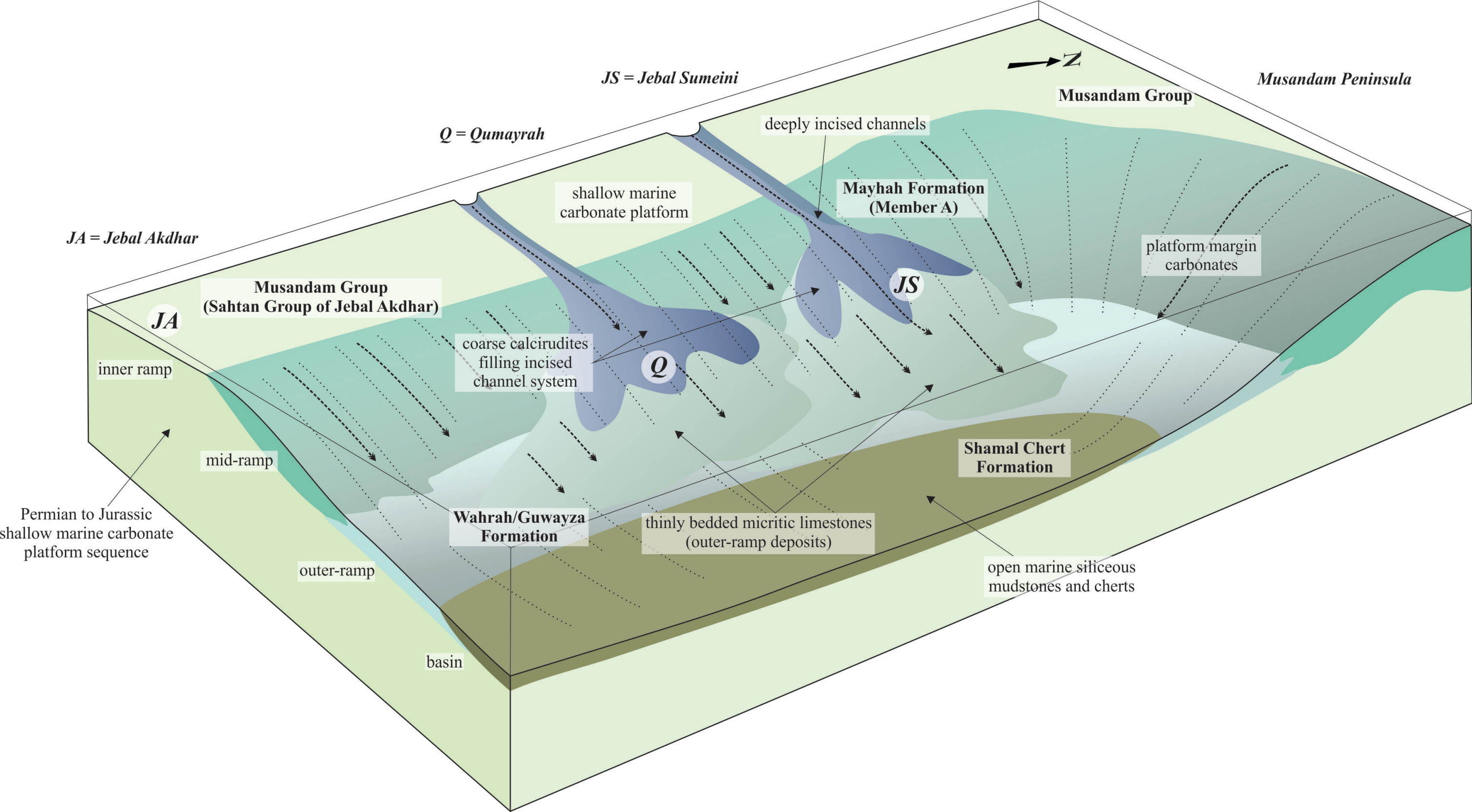




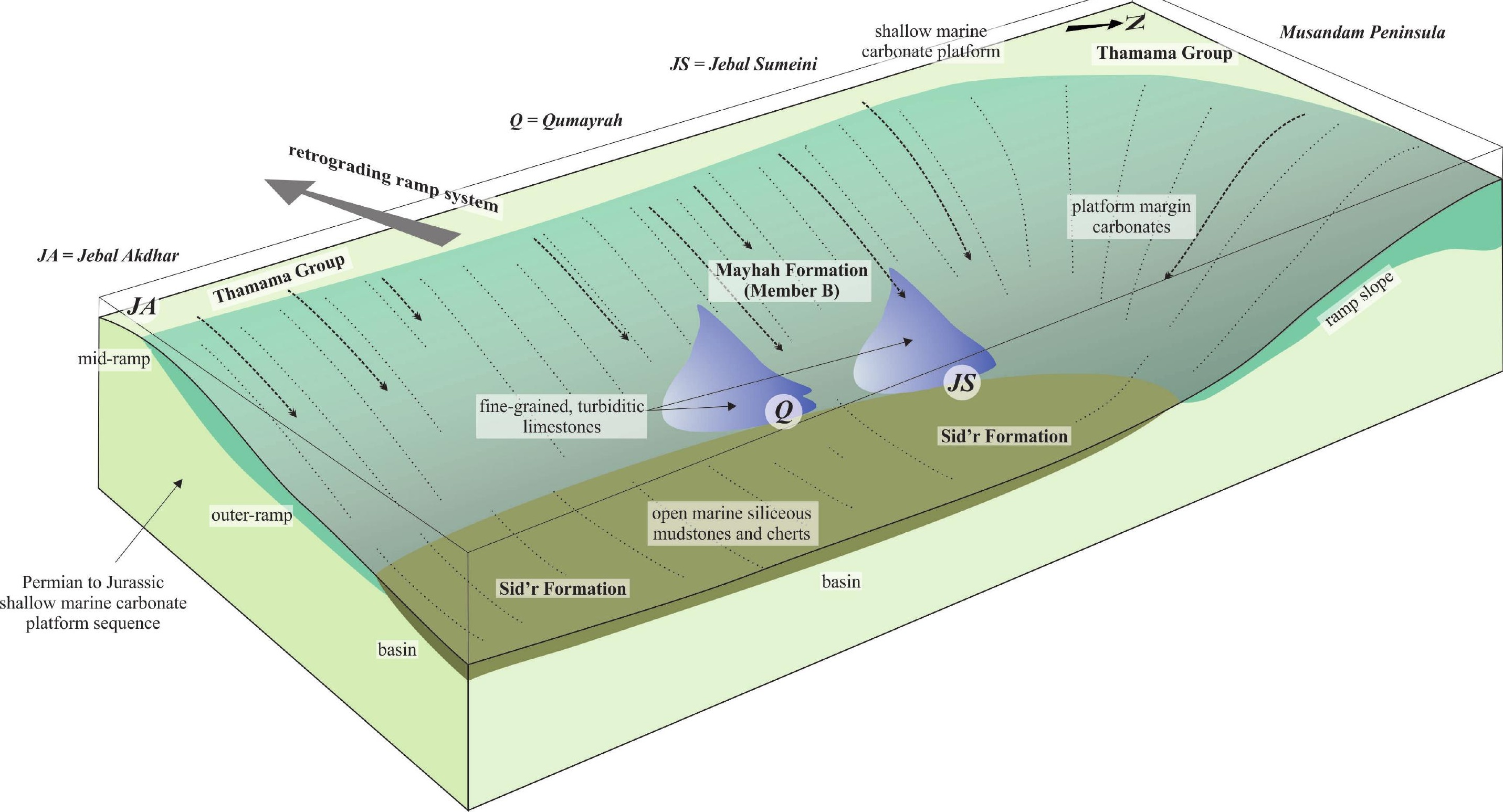



small reefs developed on fault scarps

\section{reef-derived detritus}

Permian to Jurassic shallow marine carbonate platform sequence

syn-sedimentary faults (e.g. Wadi Batha Mahani Fault) shallow marine carbonate platform
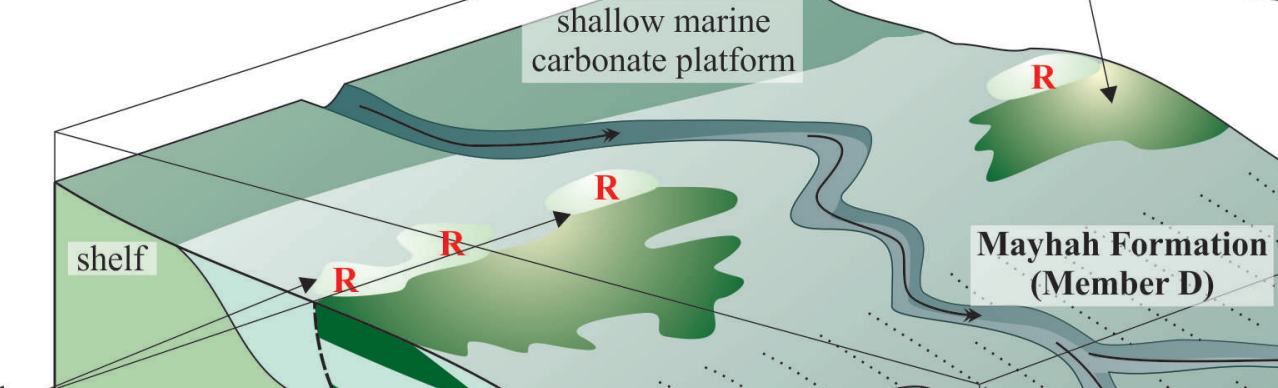
(Member D)
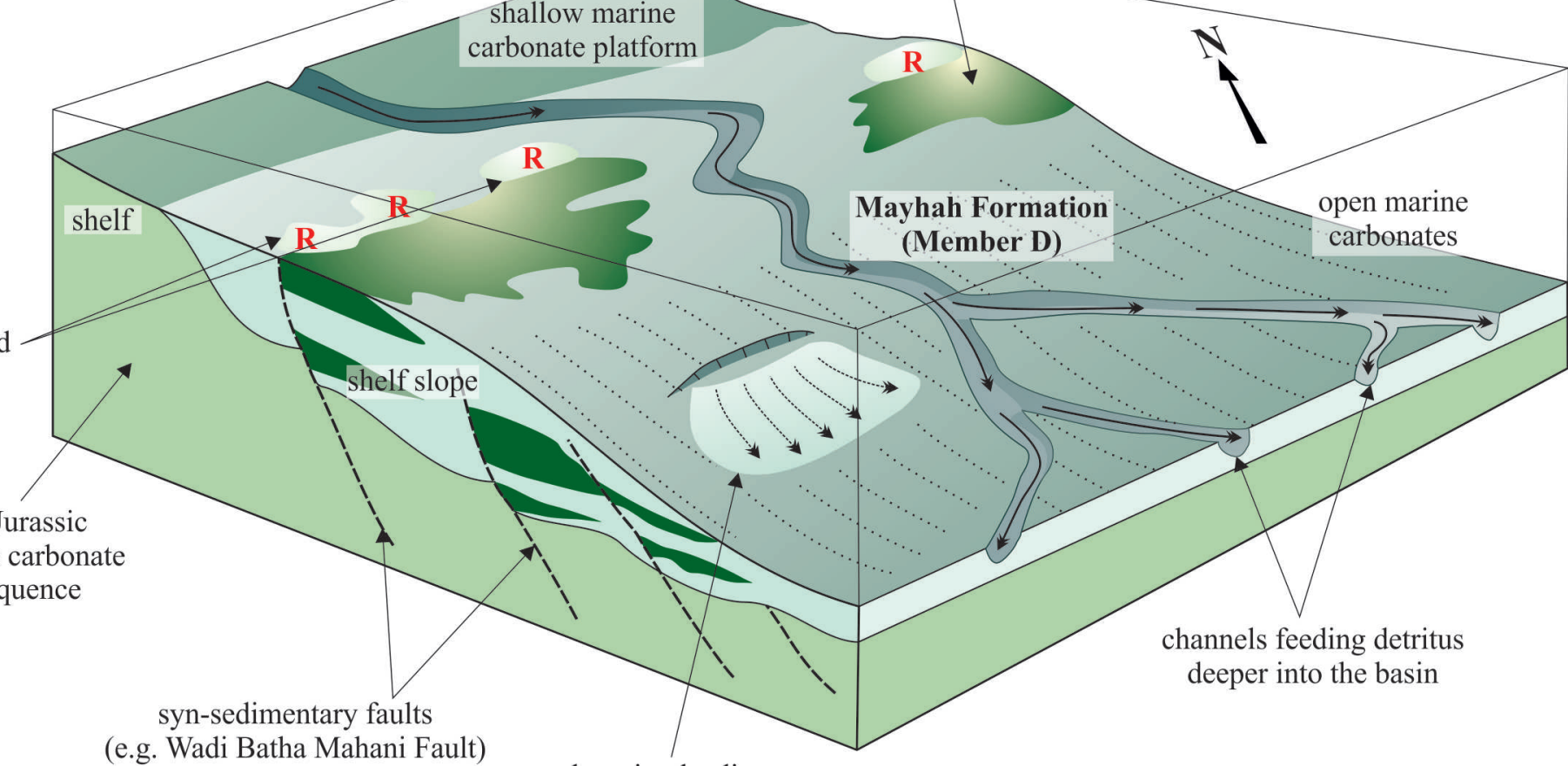

channels feeding detritus open marine carbonates deeper into the basin

to low-angle detachments and disharmonic folding 
possible fan lobe development

within more distal parts of

the Qumayrah Formation

Ausaq Conglomerate

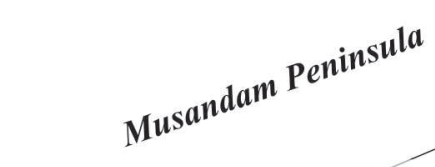

open marine siliceous mudstones carbonates and cherts

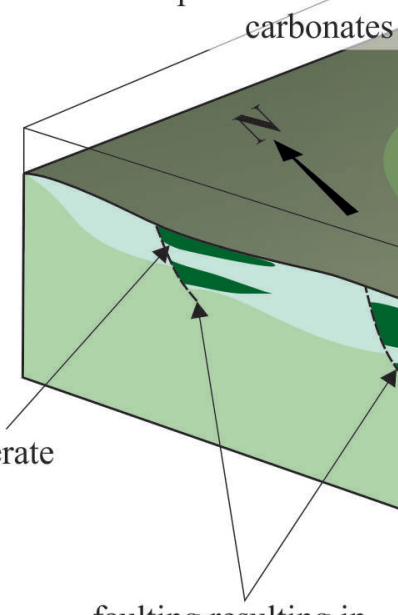

faulting resulting in foundering and deepening at platform margin (e.g. Wadi Batha Mahani Fault) slumping and mélange deposition thrusting associated with ophiolite emplacement

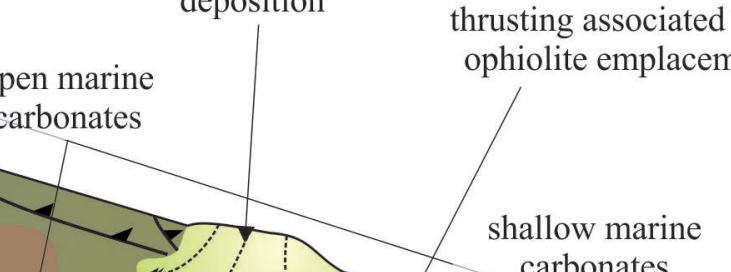

carbonates

Permian to Jurassic

Mayhah Formation

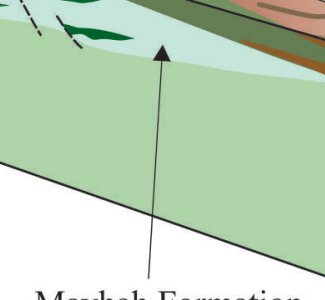

Qumayrah Member

shallow marine carbonate

platform sequence 
Table 1 Summary of the main features of the carbonate platform of the Hajar Supergroup at outcrop

\begin{tabular}{|c|c|c|c|c|c|c|c|c|}
\hline \multicolumn{2}{|c|}{ Lithostratigraphy } & \multicolumn{2}{|l|}{ Lithology } & \multicolumn{2}{|l|}{ Environment of deposition } & Thickness & Age & $\begin{array}{l}\text { Key } \\
\text { references }\end{array}$ \\
\hline \multicolumn{9}{|c|}{ Carbonate Platform succession of the Hajar Supergroup } \\
\hline \multirow{2}{*}{ 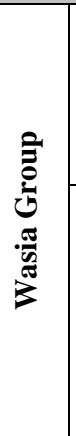 } & $\begin{array}{l}\text { Natih } \\
\text { Formation }\end{array}$ & \multicolumn{2}{|c|}{$\begin{array}{l}\text { Coarse bioclastic Orbitolina wackestone and } \\
\text { packstone, rudist packstone-floatstone, peloidal } \\
\text { intraclast packstone and grainstone succession. }\end{array}$} & $\begin{array}{l}\text { Platform rim of bioclastic shoals } \\
\text { or rudist biostromes with back- } \\
\text { shoal bioclastic packstone and } \\
\text { lagoonal foraminiferal lime } \\
\text { mudstones. }\end{array}$ & \multirow{2}{*}{$\begin{array}{l}\text { UAE: shallow water, } \\
\text { restricted or lagoonal, } \\
\text { inner ramp setting. } \\
\text { Overall shallowing } \\
\text { upwards sequence } \\
\text { with increasing } \\
\text { number of } \\
\text { hardgrounds towards } \\
\text { the top. }\end{array}$} & $280 \mathrm{~m}$ & $\begin{array}{l}\text { Late Albian to } \\
\text { Cenomanian }\end{array}$ & \multirow{2}{*}{$\begin{array}{l}\text { Glennie et al. } \\
\text { 1974; van } \\
\text { Buchem et al. } \\
\text { 2002b; } \\
\text { Simmons \& } \\
\text { Hart 1987; } \\
\text { Philip et al. } \\
\text { 1995; } \\
\text { Immenhauser } \\
\text { et a., 1999; } \\
\text { Styles et al. } \\
\text { 2006; }\end{array}$} \\
\hline & $\begin{array}{l}\text { Nahr Umr } \\
\text { Formation }\end{array}$ & \multicolumn{2}{|c|}{$\begin{array}{l}\text { Peloidal Orbitolina packstone and wackestone in } \\
\text { upward-fining cycles capped by thin reddish brown } \\
\text { mudstone beds. }\end{array}$} & $\begin{array}{l}\text { Deposited within Bab intra-shelf } \\
\text { basin with significant influx of } \\
\text { terrigenous clastic input from the } \\
\text { Arabian shield to the north-west. }\end{array}$ & & $150 \mathrm{~m}$ & $\begin{array}{l}\text { Albian. } \\
\text { Late Aptian } \\
\text { earliest age in } \\
\text { UAE. }\end{array}$ & \\
\hline \multirow{5}{*}{ 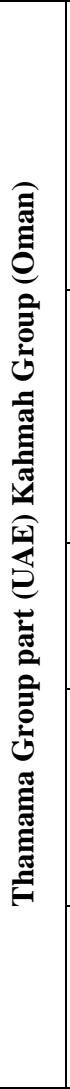 } & $\begin{array}{l}\text { Shuaiba } \\
\text { Formation }\end{array}$ & $\begin{array}{l}\text { Jebal Akhdar: } \\
\text { Dark grey, orbitolinid } \\
\text { wackestone, thickly } \\
\text { bedded and burrowed } \\
\text { throughout. Algal } \\
\text { laminites in lower part } \\
\text { and rudist facies } \\
\text { towards top. }\end{array}$ & $\begin{array}{l}\text { Northern UAE: grey } \\
\text { wackestones and } \\
\text { packestones passing up into } \\
\text { rudist packestones. }\end{array}$ & $\begin{array}{l}\text { Jebal Akhdar: Lower part } \\
\text { deposited in restricted inner shelf } \\
\text { setting and upper rudist facies } \\
\text { deposited in an open-marine high } \\
\text { energy outer to inner shelf }\end{array}$ & \multirow[t]{2}{*}{$\begin{array}{l}\text { Northern UAE: } \\
\text { shallow water inner, } \\
\text { low angle, carbonate } \\
\text { ramp; overall } \\
\text { shallowing upwards }\end{array}$} & $85 \mathrm{~m}$ & Aptian & \multirow{2}{*}{$\begin{array}{l}\text { Glennie et } \\
\text { al.,1974; } \\
\text { Biehler et al. } \\
\text { 1975; } \\
\text { Simmons \& } \\
\text { Hart 1987; } \\
\text { van Buchem } \\
\text { et al., 2002a; } \\
\text { Styles et al. } \\
2006\end{array}$} \\
\hline & $\begin{array}{l}\text { Kharaib } \\
\text { Formation }\end{array}$ & $\begin{array}{l}\text { Jebal Akhdar: Peloidal } \\
\text { grainstone, algal-- } \\
\text { foraminifera packstone } \\
\text { and orbitolinid } \\
\text { packstone, with } \\
\text { common burrows and } \\
\text { Ostrea debris. }\end{array}$ & & $\begin{array}{l}\text { Jebal Akhdar: Highstand high- } \\
\text { energy shallow water succession, } \\
\text { deposited in a system of bars and } \\
\text { intervening channels, overlain by a } \\
\text { transgressive orbitolinid packstone } \\
\text { deposits of a protected } \\
\text { argillaceous lagoon. }\end{array}$ & & $150 \mathrm{~m}$ & $\begin{array}{l}\text { Barremian to } \\
\text { early Aptian. }\end{array}$ & \\
\hline & $\begin{array}{l}\text { Habshan } \\
\text { "facies" }\end{array}$ & \multicolumn{2}{|c|}{$\begin{array}{l}\text { Northern UAE: pale grey packstones and mudstones } \\
\text { with numerous stacked channels with coarse to very } \\
\text { coarse grainstone }\end{array}$} & \multicolumn{2}{|c|}{$\begin{array}{l}\text { Northern UAE: gravity flows of reefal fragments and } \\
\text { carbonate debris from platform margin; prograding } \\
\text { eastwards }\end{array}$} & $300 \mathrm{~m}$ & early Aptian & $\begin{array}{l}\text { Eilrich \& } \\
\text { Grötsch } \\
\text { 2003; Styles } \\
\text { et al. } 2006\end{array}$ \\
\hline & $\begin{array}{l}\text { Salil } \\
\text { "facies" }\end{array}$ & \multicolumn{2}{|c|}{$\begin{array}{l}\text { Northern UAE: pale grey siliceous lime-mudstones } \\
\text { locally contain belemnites and layers of black chert } \\
\text { nodules, sponge spicules, sparse planktonic } \\
\text { foraminifera, radiolaria and calpionellids. Channels } \\
\text { contain metre-scale blocks of very coarse-grained algal } \\
\text { grainstone in a lime-mudstone matrix }\end{array}$} & \multicolumn{2}{|c|}{$\begin{array}{l}\text { Northern UAE: pelagic sedimentation and intermittent } \\
\text { gravity flows; prograding eastwards }\end{array}$} & $250 \mathrm{~m}$ & $\begin{array}{l}\text { Hauterivian- } \\
\text { Barremian }\end{array}$ & $\begin{array}{l}\text { Eilrich \& } \\
\text { Grötsch } \\
\text { 2003; Styles } \\
\text { et al. } 2006\end{array}$ \\
\hline & $\begin{array}{l}\text { Rayda } \\
\text { "facies" }\end{array}$ & \multicolumn{2}{|c|}{$\begin{array}{l}\text { Northern UAE: unsorted diamicton with } \leq 1.5 \mathrm{~m} \\
\text { diameter carbonate clasts }\end{array}$} & \multicolumn{2}{|c|}{$\begin{array}{l}\text { High energy transport of semiconsolidated carbonate debris, } \\
\text { with channelling. Outer ramp environment, with channels } \\
\text { transporting blocks of inner ramp carbonates; coral-bearing } \\
\text { grainstone derived from the Musandam } 3 \text { Formation, and } \\
\text { pale grey lime-mudstone derived from the Thamama Group }\end{array}$} & $<50 \mathrm{~m}$ & $\begin{array}{l}\text { ? Berriaisian } \\
\text { to -Barremian }\end{array}$ & \\
\hline 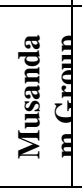 & $\begin{array}{l}\text { Musandam } \\
3 \text { Formation }\end{array}$ & \multicolumn{2}{|c|}{$\begin{array}{l}\text { Cross-bedded, coarse-grained bioclastic, peloidal and } \\
\text { oncoidal grainstone, with coral fragments and local } \\
\text { intraformational pebble-conglomerate beds. Nodules } \\
\text { and discontinuous bands of chert occur towards the } \\
\text { top. }\end{array}$} & \multicolumn{2}{|c|}{$\begin{array}{l}\text { High-energy shoals at or close to the shelf margin. The rate } \\
\text { of carbonate production appears to have slowed, resulting in } \\
\text { silicification, immediately before emergence and erosion } \\
\text { associated with the unconformity at the top of the group. }\end{array}$} & $250 \mathrm{~m}$ & $\begin{array}{l}\text { Callovian- } \\
\text { Kimmeridgian }\end{array}$ & $\begin{array}{l}\text { Glennie et al. } \\
\text { 1974; Biehler } \\
\text { et al. } 1975 \text {; } \\
\text { Le Métour et } \\
\text { al. } 1992 \text {; }\end{array}$ \\
\hline
\end{tabular}




\begin{tabular}{|c|c|c|c|c|c|}
\hline $\begin{array}{l}\text { Musandam } \\
2 \text { Formation }\end{array}$ & $\begin{array}{l}\text { Lower unit: grainstone interbedded with wackestone } \\
\text { and Lithiotis-bearing packstone; Middle unit: algal- } \\
\text { laminated limestone, lime-mudstone, oncolitic } \\
\text { wackestone, occasional coarse bioclastic grainstone; } \\
\text { Upper unit: rhythmically (decimetre-scale) bedded } \\
\text { lime-mudstone, wackestone, bioclastic packstone and } \\
\text { grainstone. Common oncolitic limestone and packstone } \\
\text { beds and subordinate oolitic and peloidal grainstone } \\
\text { and nodular limestone. Irregular burrowed erosion } \\
\text { surfaces and hardgrounds are common throughout. }\end{array}$ & $\begin{array}{l}\text { Lower and Middle units: low energy, near-shore tidal mud } \\
\text { flats and sabkhas, and sub-tidal, moderate- to high-energy } \\
\text { environments. Upper unit: fluctuations from emergence and } \\
\text { development of hardgrounds, through protected lagoons } \\
\text { (oncoid-bearing limestone) to high-energy shoals (cross- } \\
\text { bedded grainstone), to an open marine shelf (bioclastic } \\
\text { packstone and bioclastic wackestone). The increase in } \\
\text { grainstone beds toward the top suggests an overall increase } \\
\text { in the energy of the depositional environment. }\end{array}$ & $\begin{array}{l}780 \mathrm{~m}: \\
\text { Lower unit } \\
90-150 \mathrm{~m} \\
\text { N-ward } \\
\text { thickening; } \\
\text { Middle unit } \\
200 \mathrm{~m} \text {; } \\
\text { Upper unit } \\
490 \mathrm{~m}\end{array}$ & $\begin{array}{l}\text { Aalenian- } \\
\text { Bathonian }\end{array}$ & \multirow[t]{2}{*}{$\begin{array}{l}\text { Styles et al } \\
2006\end{array}$} \\
\hline $\begin{array}{l}\text { Musandam } \\
1 \text { Formation }\end{array}$ & $\begin{array}{l}\text { Lower unit: variably dolomitic, bioclastic, peloidal, } \\
\text { oolitic and oncoidal wackestone with desiccation } \\
\text { cracks and hardgrounds; Middle unit: bioclastic } \\
\text { wackestone and algal beds with oncoidal limestones; } \\
\text { Upper unit: coarsening-upwards algal- and cryptalgal- } \\
\text { laminated limestone, nodular limestone, lime- } \\
\text { mudstone, oncoidal limestone and subordinate cross- } \\
\text { bedded oolitic grainstone and bioclastic grainstone and } \\
\text { packstone. }\end{array}$ & $\begin{array}{l}\text { Low energy, near-shore tidal mud flats and sabkhas with } \\
\text { periodic emergence (algal- and cryptalgal limestone and } \\
\text { nodular limestone), sub-tidal, moderate- to high-energy } \\
\text { environments (bioclastic and peloidal grainstone and } \\
\text { bioclastic packstone) and restricted, shallow marine } \\
\text { conditions (oncoidal limestone). Coarsening-upwards cycles } \\
\text { in the upper part may represent minor flooding events, with } \\
\text { transition from tidal to sub-tidal environments. }\end{array}$ & $\begin{array}{l}250 \mathrm{~m} \text {; } \\
\text { lower unit } \\
60 \mathrm{~m} \text { thick }\end{array}$ & $\begin{array}{l}\text { Hettangian- } \\
\text { Toarcian }\end{array}$ & \\
\hline
\end{tabular}


Table 2 Summary of the main features of the carbonate platform margin sedimentary sequence

\begin{tabular}{|c|c|c|c|c|c|c|}
\hline \multicolumn{2}{|c|}{ Lithostratigraphy } & Lithology & Environment of deposition & Thickness & Age & Key references \\
\hline \multicolumn{7}{|c|}{ Carbonate Platform margin } \\
\hline \multirow[b]{2}{*}{ 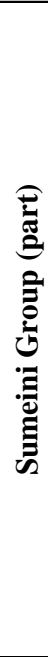 } & $\begin{array}{l}\text { Ausaq } \\
\text { Conglomerate } \\
\text { Formation }\end{array}$ & $\begin{array}{l}\text { UAE (Dibba Zone): poorly bedded, poorly-sorted, } \\
\text { boulder-grade calcirudite with clasts derived from the } \\
\text { underlying Permian to Lower Cretaceous platform } \\
\text { carbonate. }\end{array}$ & $\begin{array}{l}\text { Debris flows deposited adjacent to syn-sedimentary } \\
\text { faults; major channels which fed coarse detritus from } \\
\text { the carbonate shelf onto the lower slope of the platform. }\end{array}$ & $\begin{array}{l}\text { up to } c . \\
100 \mathrm{~m}\end{array}$ & $\begin{array}{l}\text { UAE: Late } \\
\text { Cretaceous } \\
\text { (?Coniacian- } \\
\text { Campanian) }\end{array}$ & $\begin{array}{l}\text { Allemann \& } \\
\text { Peters 1972; } \\
\text { Searle et al. } \\
\text { 1983; Styles et } \\
\text { al. } 2006\end{array}$ \\
\hline & $\begin{array}{l}\text { Mayhah } \\
\text { Formation }\end{array}$ & $\begin{array}{l}\text { Jebal Sumeini: calcirudite interbedded with thin- } \\
\text { bedded lime-mudstone and grainstone, overlain by } \\
\text { chert, in turn overlain by a thick calcirudite, passing } \\
\text { up in to thinly bedded ooidal, bioclastic and } \\
\text { lithoclastic grainstone, calcirudites, calcareous } \\
\text { mudstone and rare radiolarian chert. } \\
\text { UAE: monotonous thinly bedded, grey lime-mudstone } \\
\text { with current ripple-lamination, small burrows, } \\
\text { hummocky cross-lamination and large accretionary } \\
\text { bedforms. Fining-upwards cycles ( } 5 \text { to } 15 \mathrm{~cm} \text {-thick), } \\
\text { from fine grainstone to lime-mudstone are present, } \\
\text { with minor reworking at some bed bases. Common } \\
\text { syn-sedimentary faulting and disharmonic folding. }\end{array}$ & $\begin{array}{l}\text { Jebal Sumeini: Thick apron of lower slope limestones } \\
\text { along an east-facing block-faulted platform margin. } \\
\text { Thinly bedded micritic limestones at Jebal Sumeini are } \\
\text { regarded as by-pass slope deposits gullied by } \\
\text { conglomerate-filled channels with debris transported } \\
\text { from the platform margin. Radiolarian cherts are } \\
\text { interpreted as starved slope deposits associated with a } \\
\text { transgressive event. Clast-supported megabreccias } \\
\text { represent avalanche deposits formed due to the collapse } \\
\text { of the carbonate platform. The top of the formation is } \\
\text { interpreted as a retrograding slope apron. } \\
\text { UAE: Mid ramp setting above storm wave base with } \\
\text { extensive submarine slumping }\end{array}$ & $\begin{array}{l}650 \mathrm{~m} \text { at } \\
\text { Jebal } \\
\text { Sumeini }\end{array}$ & $\begin{array}{l}\text { UAE: Late } \\
\text { Cretaceous } \\
\text { (?Coniacian- } \\
\text { Campanian). } \\
\text { Jebal Sumeini: } \\
\text { Early Jurassic - } \\
\text { Early Cretaceous } \\
\text { (Barremian-- } \\
\text { Aptian) }\end{array}$ & $\begin{array}{l}\text { Allemann \& } \\
\text { Peters 1972; } \\
\text { Glennie et al. } \\
\text { 1974; Watts \& } \\
\text { Garrison 1986; } \\
\text { Watts 1990; } \\
\text { Watts \& Blome } \\
\text { 1990; Styles et } \\
\text { al. 2006 }\end{array}$ \\
\hline
\end{tabular}


Table 3 Summarv of the main features of the outer platform margin to basin sedimentarv seauence

\begin{tabular}{|c|c|c|c|c|c|c|}
\hline \multicolumn{2}{|c|}{ Lithostratigraphy } & Lithology & Environment of deposition & Thickness & Age & Key references \\
\hline \multicolumn{7}{|c|}{ Outer platform margin to basin } \\
\hline \multirow{6}{*}{ 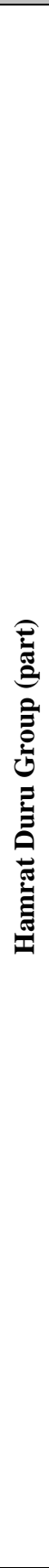 } & $\begin{array}{l}\text { Guwayza } \\
\text { Formation }\end{array}$ & $\begin{array}{l}\text { Lower unit: brown, medium-grained sandstone and } \\
\text { sandy calcarenite with high modal proportion of detrital } \\
\text { quartz; Upper unit: ooidal to peloidal, variably silicified } \\
\text { dolomitic grainstone, metre-thick graded beds with } \\
\text { parallel- and cross-lamination, locally convoluted } \\
\text { 'swaley' cross stratification. Sharp erosive bases and } \\
\text { sole-marks (flutes, grooves). Interbedded with silicified } \\
\text { argillaceous radiolarian wackestone and mudstone. }\end{array}$ & $\begin{array}{l}\text { Widespread soft sediment deformation suggests deposition } \\
\text { on unstable slopes presumably in an outer ramp } \\
\text { environment }\end{array}$ & $580 \mathrm{~m}$ & $\begin{array}{l}\text { Mid - Late } \\
\text { Jurassic } \\
\text { (Bathonian - } \\
\text { Callovian) }\end{array}$ & \multirow{6}{*}{$\begin{array}{l}\text { Harembourne \& } \\
\text { Horstink 1967; } \\
\text { Wilson 1969; } \\
\text { Glennie et al. } \\
\text { 1974; Cooper } \\
\text { 1990; Robertson } \\
\text { et al. 1990a \& } \\
\text { b; Kickmaier \& } \\
\text { Peters 1991; } \\
\text { Styles et al. } \\
\text { 2006. }\end{array}$} \\
\hline & $\begin{array}{l}\text { Wahrah } \\
\text { Formation }\end{array}$ & $\begin{array}{l}\text { Heterogeneous thinly bedded radiolarian chert, graded } \\
\text { metre-thick beds of grey-brown and dark brown, } \\
\text { medium- to fine-grained, oolitic grainstone with ripples, } \\
\text { parallel- and cross-lamination and flute and groove } \\
\text { casts, pale grey to yellow-brown, thinly bedded, } \\
\text { variably silicified radiolarian calcareous mudstone with } \\
\text { pale grey fine-grained turbiditic limestone. }\end{array}$ & $\begin{array}{l}\text { Deep-marine suspension deposition punctuated by periodic } \\
\text { turbidite deposition, with the formation probably } \\
\text { representing a more distal facies and/or lateral equivalent } \\
\text { to the Nayid Formation. }\end{array}$ & $185 \mathrm{~m}$ & $\begin{array}{l}\text { Late } \\
\text { Triassic - } \\
\text { Early } \\
\text { Cretaceous }\end{array}$ & \\
\hline & $\begin{array}{l}\text { Sid'r Chert } \\
\text { Formation }\end{array}$ & $\begin{array}{l}\text { Thin bedded ( } \leq 15 \mathrm{~cm} \text { thick) radiolarian chert and } \\
\text { siliceous mudstone with lenses and beds of coarse sand- } \\
\text { to granule-grade turbiditic calcarenite }\left(\mathrm{T}_{\mathrm{ab}}, \mathrm{T}_{\mathrm{abc}}, \mathrm{T}_{\mathrm{bcd}}\right. \\
\text { beds) and microconglomerate (up to } 3 \mathrm{~m} \text { thick). }\end{array}$ & $\begin{array}{l}\text { Outer ramp with limestones in coarsening and fining } \\
\text { upward sequences recording progressive onset and waning } \\
\text { of the 'pulses' of distal turbidite deposition. Intervening } \\
\text { cherts indicate prolonged periods of little clastic } \\
\text { deposition. Possibly distal facies and/or lateral equivalent } \\
\text { to the Dhera and Dibba limestone formations. }\end{array}$ & $140 \mathrm{~m}$ & $\begin{array}{l}\text { Tithonian - } \\
\text { Barremian; } \\
\text { possibly to } \\
\text { early } \\
\text { Campanian } \\
\text { age in UAE }\end{array}$ & \\
\hline & $\begin{array}{l}\text { Nayid } \\
\text { Formation }\end{array}$ & $\begin{array}{l}\text { Jebal Sumeini: Thin to very thin bedded }(0.5-20 \mathrm{~cm}) \\
\text { platy calcilutites ( } \mathrm{T}_{\mathrm{cd}} \text { Bouma beds) and calcarenites }\left(\mathrm{T}_{\mathrm{abc}}\right. \\
\text { and } \mathrm{T}_{\mathrm{abcd}} \text { Bouma beds) with Arenicolites traces. The } \\
\text { number and thickness of clast-supported and massive } \\
\text { calcirudite beds increase upwards. } \\
\text { Hamrat Duru: Thinly bedded lithoclastic and peloidal, } \\
\text { variably silicified, turbiditic grainstone and packstone } \\
\left(\mathrm{T}_{\mathrm{ab}}, \mathrm{T}_{\mathrm{abc}} \text { and } \mathrm{T}_{\mathrm{bcd}} \text { Bouma beds) with interbeds of }\right. \\
\text { laminated calcareous mudstone with Arenicolites and } \\
\text { Paleodictyon traces. Common pebbly calcarenite to } \\
\text { calcirudite beds, massive, clast-supported, matrix-poor } \\
\text { to graded, containing Permian derived detritus. }\end{array}$ & $\begin{array}{l}\text { Jebal Sumeini: Relatively distal turbiditic limestone with } \\
\text { intraformational clasts due to localised uplift and erosion. } \\
\text { Intraclasts were lithified prior to reworking, suggesting } \\
\text { very early diagenesis, the carbonate cement indicating } \\
\text { cementation probably occurred above CCD. Cherts record } \\
\text { either an increase in water depth and/or switching off of } \\
\text { carbonate clastic input. Basaltic detritus may indicate } \\
\text { sedimentation was coincident with volcanism. } \\
\text { Hamrat Duru: Relatively proximal turbiditic limestone, } \\
\text { with thickening and coarsening upwards thought to record } \\
\text { development of individual prograding fan lobes. } \\
\text { Calcirudites form single/amalgamated mass flow deposits. }\end{array}$ & $210 \mathrm{~m}$ & $\begin{array}{l}\text { Barremian - } \\
\text { Cenomanian }\end{array}$ & \\
\hline & $\begin{array}{l}\text { Dhera } \\
\text { Limestone } \\
\text { Formation }\end{array}$ & $\begin{array}{l}\text { Heterogeneously deformed, variably silicified, thinly } \\
\text { bedded turbiditic calcarenite ( } \mathrm{T}_{\text {abcd }} \text { to } \mathrm{T}_{\mathrm{cd}} \text { Bouma beds), } \\
\text { pebble- to boulder-grade, clast-supported calcirudite (up } \\
\text { to } 50 \mathrm{~m} \text {-thick), very thinly bedded to parallel-laminated } \\
\text { calcilutite and thinly bedded radiolarian chert and } \\
\text { siliceous mudstone. Planolites, Nereites, Arenicolites, } \\
\text { Spirorhaphe, Helminthoida to Cosmorhaphe-type traces } \\
\text { are found locally. }\end{array}$ & $\begin{array}{l}\text { Coarsening and thickening upward may represent } \\
\text { progradation of the outer margin of turbidite fan lobes into } \\
\text { the deeper mud-dominated parts of the basin. Calcirudites } \\
\text { represent channelised mass flow deposits. Load structures, } \\
\text { soft-sediment deformation of calcilutites and climbing } \\
\text { ripple-drift lamination in calcarenites indicate high } \\
\text { sedimentation rates. Inferred deposition below CCD, with } \\
\text { silicification occurring as input of clastic carbonate waned. }\end{array}$ & $300-400 \mathrm{~m}$ & $\begin{array}{l}\text { Berriasian - } \\
\text { late Aptian, } \\
\text { possibly } \\
\text { Maastrich- } \\
\text { tian from } \\
\text { radiolarians }\end{array}$ & \\
\hline & $\begin{array}{l}\text { Dibba } \\
\text { Limestone } \\
\text { Formation }\end{array}$ & $\begin{array}{l}\text { Thick bedded }(0.5-1.5 \mathrm{~m}) \text {, variably silicified turbiditic } \\
\text { calcarenite }\left(\mathrm{T}_{\mathrm{ab}}, \mathrm{T}_{\mathrm{abc}} \text { and } \mathrm{T}_{\mathrm{abcd}} \text { beds }\right) \text { and poorly sorted, } \\
\text { clast-supported pebble- to boulder-calcirudite with } \\
\text { minor interbedded calcilutite. The calcarenites include } \\
\text { graded bedding, parallel- and cross-lamination, climbing } \\
\text { ripple-drift lamination and sole structures. }\end{array}$ & $\begin{array}{l}\text { Proximal to medial sand-rich turbidite fan with calcirudites } \\
\text { deposited as channelised mass flow or canyon-fill deposits. } \\
\text { Thicker calcarenite beds formed as amalgamated turbidite } \\
\text { flows. Similar provenance to the more distal turbiditic } \\
\text { succession of the Dhera Limestone Formation, largely } \\
\text { derived from an older Jurassic limestone source. }\end{array}$ & c. $300 \mathrm{~m}$ & $\begin{array}{l}\text { Triassic to } \\
\text { Mid } \\
\text { Cretaceous }\end{array}$ & \\
\hline
\end{tabular}


Table 4 Summary of the main features of the basinal sedimentary sequence and volcanic rocks

\begin{tabular}{|c|c|c|c|c|c|c|}
\hline \multicolumn{2}{|c|}{ Lithostratigraphy } & Lithology & Environment of deposition & Thickness & Age & Key references \\
\hline \multicolumn{7}{|c|}{ Basinal deposits and volcanic rocks } \\
\hline \multirow{3}{*}{ 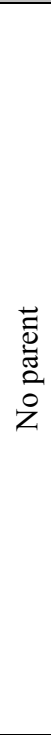 } & $\begin{array}{l}\text { Dibba } \\
\text { Volcanic } \\
\text { Formation }\end{array}$ & $\begin{array}{l}\text { Massive to pillow basalt lavas interbedded with massive to poorly- } \\
\text { bedded pyroclastic (lava breccia, agglomerate, lapilli-tuff, tuff) and } \\
\text { volcaniclastic (breccia and sandstone) rocks, as well as occasional } \\
\text { thinly bedded ( } \leq 20 \mathrm{~cm} \text { thick) radiolarian cherts and siliceous } \\
\text { mudstones. Mélanges comprise metre-scale olistoliths of chert, } \\
\text { limestone and basalt within a crudely bedded tuffaceous matrix. }\end{array}$ & \multirow{2}{*}{$\begin{array}{l}\text { Close association of chert mélange with } \\
\text { basaltic volcanic rocks suggests the } \\
\text { mélange was generated due to slumping } \\
\text { in response to volcanic related seismic } \\
\text { activity. } \\
\text { The formations display geochemical } \\
\text { characteristics typical of alkaline } \\
\text { volcanic rocks erupted in an oceanic } \\
\text { within-plate setting, with a minor suite of } \\
\text { sub-alkaline basalts to basaltic andesites } \\
\text { which exhibit characteristics of mid- } \\
\text { ocean ridge basalts. }\end{array}$} & Unknown & $\begin{array}{l}\text { Cenomanian } \\
\text { - Turonian }\end{array}$ & $\begin{array}{l}\text { Allemann \& Peters } \\
\text { 1972; Glennie et al. } \\
\text { 1974; Lippard \& Rex } \\
\text { 1982; Robertson et } \\
\text { al. 1990a; Styles et } \\
\text { al. 2006 }\end{array}$ \\
\hline & $\begin{array}{l}\text { Hatta } \\
\text { Volcanic } \\
\text { Formation }\end{array}$ & $\begin{array}{l}\text { Amygdaloidal to vesicular basalt pillow lava and massive to poorly } \\
\text { bedded coarse-grained volcaniclastic sandstone, breccia and } \\
\text { conglomerate, interbedded with chert, siliceous mudstone and } \\
\text { limestone. The formation is intruded by a number of irregular to } \\
\text { sheet-like lamprophyric basalt to microgabbro sills and dykes. }\end{array}$ & & Unknown & Albian & Styles et al. 2006 \\
\hline & $\begin{array}{l}\text { Shamal Chert } \\
\text { Formation }\end{array}$ & $\begin{array}{l}\text { Thinly bedded, variably deformed chert and siliceous mudstone with } \\
\text { occasional thin }(<10 \mathrm{~cm}) \text { beds or lenses of a fine-grained peloidal } \\
\text { and turbiditic limestone and thicker beds }(\leq 30 \mathrm{~cm} \text { thick) of fine- } \\
\text { grained sandstone. Locally contains lenses of poorly bedded to } \\
\text { massive calcirudite and lenses of very fine-grained, olivine and/or } \\
\text { pyroxene phyric basaltic pillow lavas, possibly alkaline, and massive } \\
\text { to poorly bedded, coarse-grained volcaniclastic rocks, as well as a } \\
\text { chert mélange. }\end{array}$ & $\begin{array}{l}\text { Deep basinal succession deposited below } \\
\text { storm wave-base and below CCD. } \\
\text { Intermittent introduction of distal } \\
\text { turbidites and slump-related mélanges. }\end{array}$ & $200-300 \mathrm{~m}$ & $\begin{array}{l}\text { Mid Late } \\
\text { Triassic to } \\
\text { late Aptian }\end{array}$ & $\begin{array}{l}\text { Glennie et al. 1974; } \\
\text { De Wever et al. } \\
\text { 1990; Styles et al. } \\
2006\end{array}$ \\
\hline
\end{tabular}

Table 5 Summary of the main features of the syn- and post-obduction foreland basin sedimentary sequence 


\begin{tabular}{|c|c|c|c|c|c|c|c|}
\hline \multicolumn{3}{|c|}{ Lithostratigraphy } & \begin{tabular}{|l} 
Lithology \\
\end{tabular} & Environment of deposition & Thickness & Age & Key references \\
\hline \multicolumn{8}{|c|}{ Syn- and post-obduction foreland basin } \\
\hline \multirow{9}{*}{ 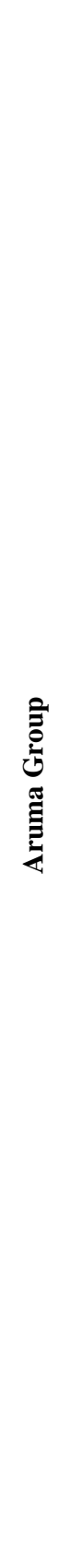 } & \multicolumn{2}{|c|}{$\begin{array}{l}\text { Simsima } \\
\text { Formation }\end{array}$} & $\begin{array}{l}\text { White, chalky mudstone-wackestone and pellet packstone- } \\
\text { wackestone, with dolomitised limestone or coarse } \\
\text { dolostone forming up to } 50 \% \text { of the lower parts of the } \\
\text { formation. Ophiolite clasts occur within basal limestone. }\end{array}$ & $\begin{array}{l}\text { Shallow marine limestones representing the first } \\
\text { marine flooding event across the flexural } \\
\text { foreland basin developed as a consequence of the } \\
\text { ophiolite obduction. }\end{array}$ & $\begin{array}{l}\text { Up to } 450 \\
\mathrm{~m}\end{array}$ & $\begin{array}{l}\text { Late } \\
\text { Maastrichtian }\end{array}$ & $\begin{array}{l}\text { Glennie et al. } \\
\text { 1974; Nolan et } \\
\text { al. } 1990\end{array}$ \\
\hline & \multicolumn{2}{|c|}{ Qahlah Formation } & $\begin{array}{l}\text { Polymictic conglomerate with clasts of Semail ophiolite } \\
\text { and Hawasina chert in an argillaceous matrix, interbedded } \\
\text { with lithic sandstone, shale and marl. Locally interbedded } \\
\text { with } 10-30 \mathrm{~m} \text { thick basaltic lavas with some pillows. }\end{array}$ & $\begin{array}{l}\text { Debris flows or sedimentary mélanges } \\
\text { (olistostromes) sourced from the erosion of the } \\
\text { tectonically emplaced Hawasina and Semail } \\
\text { ophiolite. }\end{array}$ & $140 \mathrm{~m}$ & $\begin{array}{l}\text { Mid } \\
\text { Maastrichtian }\end{array}$ & $\begin{array}{l}\text { Glennie et al. } \\
\text { 1974; Skelton et } \\
\text { al. } 1990\end{array}$ \\
\hline & \multicolumn{2}{|c|}{ Muti Formation } & $\begin{array}{l}\text { Jebal Akhdar: Concretionary and argillaceous limestone } \\
\text { (packstone and wackestone) with basal oolitic ironstone } \\
\text { with shelly fauna and phosphatic deposits. Overlain by } \\
\text { shale, redeposited carbonate and siliciclastics, calcirudites } \\
\text { and slump-sheets, with thick-bedded grainstones in upper } \\
\text { part. NW Dibba Zone: pelagic pale yellowish to orange- } \\
\text { brown lime-mudstone with basal glauconitic limestone, } \\
\text { cross-laminated with Teichichnus traces. }\end{array}$ & $\begin{array}{l}\text { Near-shore shallow shoal and bioclastic bank } \\
\text { (oolitic ironstone) redeposited in a deeper water } \\
\text { high-energy setting. Overlying argillaceous } \\
\text { succession deposited in moderately deep-water } \\
\text { (10 to } 100 \mathrm{~m} \text { ) low-energy shelf. Upper part } \\
\text { shows increase in proportion and thickness of } \\
\text { grainstone beds suggesting shallowing-upward } \\
\text { succession with shallow marine shoal grainstone. }\end{array}$ & $\begin{array}{l}\text { c. } 350 \mathrm{~m} \text { at } \\
\text { Jebal } \\
\text { Akhdar; } 50 \\
\mathrm{~m} \text { in NW } \\
\text { Dibba Zone }\end{array}$ & $\begin{array}{l}\text { Jebal Akhdar: } \\
\text { base Turonian } \\
\text { - Coniacian; } \\
\text { top Santonian } \\
\text { to Campanian. } \\
\text { UAE:?late } \\
\text { Albian - } \\
\text { Coniacian. } \\
\end{array}$ & $\begin{array}{l}\text { Glennie et al. } \\
\text { 1974; Robertson } \\
\text { 1987; Alsharhan } \\
\text { \& Nairn 1997; }\end{array}$ \\
\hline & \multirow{2}{*}{ 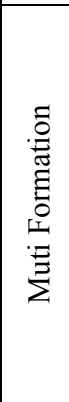 } & $\begin{array}{l}\text { Qumayrah } \\
\text { Member }\end{array}$ & $\begin{array}{l}\text { Thin to thick bedded ( } \leq 60 \mathrm{~cm}-3 \mathrm{~m} \text { thick) medium- to } \\
\text { coarse-grained turbiditic calcarenite, minor granule- to } \\
\text { pebble-grade calcirudite and calcareous to siliceous } \\
\text { mudstone. Zoophycos to Nereites ichnofacies trace fossils } \\
\text { including Paleodictyon, Arenicolites, Planolites, } \\
\text { Ophiomorpha, Chondrites-like burrows, and Nereites-like } \\
\text { trails (?Helminthoida) are present. }\end{array}$ & $\begin{array}{l}\text { Outer ramp with reworked inner ramp oolitic and } \\
\text { peloidal calcarenite. Silicified radiolarian } \\
\text { mudstones represent pelagic deposition below } \\
\text { CCD. Megabreccias record gravitational } \\
\text { instabilities associated with the collapse of the } \\
\text { carbonate platform margin, culminating with } \\
\text { deposition of thick olistoliths in the upper part. }\end{array}$ & c. $800 \mathrm{~m}$ & $\begin{array}{l}\text { Silicified } \\
\text { mudstone of } \\
\text { Coniacian age }\end{array}$ & $\begin{array}{l}\text { Watts \& Blome } \\
\text { 1990; Watts } \\
\text { 1990 }\end{array}$ \\
\hline & & $\begin{array}{l}\text { Riyamah } \\
\text { Member }\end{array}$ & $\begin{array}{l}\text { Siliceous mudstone with interbeds of radiolarian chert and } \\
\text { lenticular bodies of turbiditic fine- to coarse-grained } \\
\text { calcarenite ( } \mathrm{T}_{\mathrm{abc}} \text { to } \mathrm{T}_{\mathrm{bcd}} \text { beds) and granule-grade } \\
\text { conglomerate }(\leq 4 \mathrm{~m} \text { thick). }\end{array}$ & $\begin{array}{l}\text { Outer ramp succession of argillaceous } \\
\text { suspension deposits with intermittent turbidite } \\
\text { flows. Calcarenite and calcirudite are interpreted } \\
\text { as channel-fill deposits. }\end{array}$ & $? \mathrm{~m}$ & $\begin{array}{l}\text { Cenomanian } \\
\text { to Campanian }\end{array}$ & \\
\hline & \multicolumn{2}{|c|}{$\begin{array}{l}\text { Al Rams Mélange } \\
\text { Formation }\end{array}$} & $\begin{array}{l}\text { Blocks up to } 1 \mathrm{~km} \text { of fractured pale grey limestone within } \\
\text { a highly disrupted mélange matrix of greenish grey } \\
\text { tuffaceous lithic sandstone, cleaved green-grey and yellow- } \\
\text { brown siliceous mudstone and conglomerate. }\end{array}$ & $\begin{array}{l}\text { Conglomerate includes clasts of shallow-water } \\
\text { limestone derived from the Wasia Group and the } \\
\text { Thamama Group. }\end{array}$ & $\begin{array}{l}\text { At least } \\
400 \mathrm{~m}\end{array}$ & $\begin{array}{l}\text { ?Campanian; } \\
\text { clasts of } \\
\text { Callovian - } \\
\text { Valanginian }\end{array}$ & $\begin{array}{l}\text { Styles et al. } \\
2006\end{array}$ \\
\hline & \multicolumn{2}{|c|}{$\begin{array}{l}\text { Kub Mélange } \\
\text { Formation }\end{array}$} & $\begin{array}{l}\text { Angular to rounded elongate olistoliths of deformed } \\
\text { limestone, quartzose sandstone, siltstone, chert and rare } \\
\text { ultramafic rocks, within a highly fissile grey-green } \\
\text { mudstone matrix. Up to } 400 \mathrm{~m} \text { blocks of polydeformed } \\
\text { metasedimentary rocks, metamafite and basaltic volcanic } \\
\text { rocks also occur. }\end{array}$ & $\begin{array}{l}\text { The basaltic olistoliths are similar to the Dibba } \\
\text { Volcanic Formation. The limestone blocks } \\
\text { within the mélange are composed of thinly } \\
\text { bedded turbiditic calcarenites, platy calcilutites } \\
\text { and calcirudites derived from the Dhera } \\
\text { Limestone Formation. }\end{array}$ & $\begin{array}{l}300-400 \\
m\end{array}$ & $\begin{array}{l}\text { ?Cenomanian } \\
\text { - Turonian }\end{array}$ & $\begin{array}{l}\text { Searle } \text { et al. } \\
\text { 1983; Robertson } \\
\text { et al. 1990a; } \\
\text { Styles et al. } \\
2006\end{array}$ \\
\hline & \multicolumn{2}{|c|}{$\begin{array}{l}\text { Wadi Sanah } \\
\text { Mélange } \\
\text { Formation }\end{array}$} & $\begin{array}{l}\text { Angular to rounded elongate blocks of deformed } \\
\text { limestone, siliceous mudstone, chert, serpentinite and rare } \\
\text { volcanic rocks within an olive green siliceous mudstone } \\
\text { matrix with an anastomosing foliation. The formation is } \\
\text { characterised by the presence of } \leq 0.5 \mathrm{~km} \text { long blocks of } \\
\text { highly serpentinised dunite, harzburgite and } \\
\text { clinopyroxene-harzburgite. }\end{array}$ & $\begin{array}{l}\text { Sedimentary mélange (olistostrome) that was } \\
\text { shed from the unstable leading edge of a thrust } \\
\text { stack which developed in front of the advancing } \\
\text { Semail ophiolite. }\end{array}$ & $? \mathrm{~m}$ & $\begin{array}{l}\text { ?Cenomanian } \\
\text { - Turonian }\end{array}$ & $\begin{array}{l}\text { Searle et al. } \\
\text { 1983; Styles et } \\
\text { al. } 2006\end{array}$ \\
\hline & \multicolumn{2}{|c|}{$\begin{array}{l}\text { Masfut Mélange } \\
\text { Formation }\end{array}$} & $\begin{array}{l}\text { Blocks of limestone, limestone conglomerate, sandstone, } \\
\text { chert, basalt and volcaniclastic breccia within a green-grey } \\
\text { to brown siliceous mudstone matrix. }\end{array}$ & $\begin{array}{l}\text { The large blocks of limestone are lithologically } \\
\text { similar to and, at least in part, derived from the } \\
\text { Dhera Limestone Formation. }\end{array}$ & $? \mathrm{~m}$ & $\begin{array}{l}\text { Cenomanian } \\
\text { or younger }\end{array}$ & $\begin{array}{l}\text { Styles et al. } \\
2006\end{array}$ \\
\hline
\end{tabular}

